\title{
Copper-catalyzed Cross-Coupling Between Alkyl (Pseudo)Halides and Bicyclopentyl Grignard Reagents
}

Claire Andersen, ${ }^{[\mathrm{a}]}$ Vincent Ferey, ${ }^{[\mathrm{b}]}$ Marc Daumas, $^{[\mathrm{c}]}$ Patrick Bernardelli, ${ }^{[\mathrm{d}]}$ Amandine Guérinot, $^{*}$

[a] Janine Cossy* [a]

[a] Molecular, Macromolecular Chemistry and Materials, ESPCI Paris, CNRS, PSL University, 10 rue Vauquelin, 75005 Paris, France. [b] Sanofi R\&D, 371 rue du Professeur Joseph Blayac, 34080 Montpellier, France. [c] Sanofi Chimie, Route d’Avignon, 30390 Aramon, France. [d] Sanofi R\&D, 1 avenue Pierre Brossolette, 91380 Chilly-Mazarin, France. 


\section{Table of Contents}

TABLE OF CONTENTS

I- ALKYL (PSEUDO)HALIDES AND GRIGNARD REAGENTS SYNTHESIS

I.1. SYNTHESIS OF PRIMARY ALKYL HALIDES

I.2. SYNTHESIS OF PRIMARY SULFONIC ESTERS

I.3. SYNTHESIS OF SECONDARY ALKYL HALIDES

I.3.1. Synthesis of cyclic secondary alkyl (pseudo)halides $\quad 8$

$\begin{array}{ll}\text { I.3.2. Synthesis of acyclic secondary iodides } & 12\end{array}$

I.4. SYNTHESIS OF THE GRIGNARD REAGENTS AND OPTIMIZATION OF THE SYNTHESIS OF THE ARYL-BCP-GRIGNARD REAGENTS 14

II- COPPER-CATALYZED CROSS-COUPLING

II.1. CROSS-COUPLING BETWEEN PRIMARY ALKYL (PSEUDO)HALIDES AND BCP GRIGNARD REAGENTS 18

II.1.1. Optimization of the cross-coupling between primary alkyl (pseudo)halides and BCP Grignard reagents 18

II.1.2. Scope of the cross-coupling between primary alkyl (pseudo)halides and BCP-Grignard reagents 20

II.2. CROSS-COUPLING BETWEEN SECONDARY ALKYL (PSEUDO)HALIDES AND BCP GRIGNARD REAGENTS 25

II.2.1. Optimization of the cross-coupling between secondary alkyl (pseudo)halides and alkyl-BCP Grignard reagents 25

II.2.2. Optimization of the cross-coupling between secondary alkyl iodides and aryl-BCP Grignard reagents 27

II.2.3. Scope of the cross-coupling with secondary alkyl (pseudo)halides 28

II.3. MECHANISTIC STUDIES 
All commercially available products were used as received without any purification. All commercially available Grignard reagents (tert-butylmagnesium chloride, cyclopentylmagnesium bromide, isopropylmagnesium chloride, $p$-fluorophenylmagnesium bromide, $p$-methoxyphenylmagnesium bromide, benzylmagnesium chloride) were titrated. ${ }^{1}$ Non-commercially available Grignard reagents in $\mathrm{Et}_{2} \mathrm{O}$ ( $p$-methoxyphenylmagnesium bromide, cyclobutylmagnesium bromide) were synthesized using standard magnesium insertion techniques and titrated. ${ }^{1} \mathrm{Et}_{2} \mathrm{O}, \mathrm{CH}_{2} \mathrm{Cl}_{2}$ and toluene were dried using a MBraun SPS800 purificator. THF was distilled over sodium and benzophenone. All synthesized iodides were dried by azeotrope removal of $\mathrm{H}_{2} \mathrm{O}$ utilizing toluene and stored in a round bottom flask wrapped with aluminium foil and cooled at $-18^{\circ} \mathrm{C}$. All reactions were performed under an argon atmosphere using a balloon (tubes or round bottom flasks with rubber septum purged with Ar balloon via needles through the septum). When heating was required, heating mantles were used. TLC were performed on silica gel plates and visualized either with a UV lamp $(254 \mathrm{~nm})$ or using a staining solution $(p$ anisaldehyde or $\mathrm{KMnO}_{4}$ ). Flash chromatography was performed on silica gel (Merck-Kieselgel 60, 230-400 mesh). ${ }^{1} \mathrm{H}$ NMR spectra were recorded on a Bruker AVANCE 400 at $400 \mathrm{MHz}$ and data are reported as follows: chemical shifts in ppm with the solvent peak as internal standard $\left(\mathrm{CDCl}_{3}, \delta 7.26\right.$ $\mathrm{ppm}$ ), multiplicity $(\mathrm{s}=$ singlet, $\mathrm{d}=$ doublet, $\mathrm{t}=$ triplet, $\mathrm{q}=$ quartet, quint $=$ quintuplet, hex $=$ hexuplet, hept $=$ heptuplet, $\mathrm{m}=$ multiplet or overlap of non-equivalent resonances, $\mathrm{br}=\mathrm{broad}) .{ }^{13} \mathrm{C}$ NMR spectra were recorded on a Bruker AVANCE 400 at $100 \mathrm{MHz}$ and data are reported as follows: chemical shifts in ppm with the solvent peak as internal standard $\left(\mathrm{CDCl}_{3}\right.$ at $\left.77.1 \mathrm{ppm}\right)$. Coupling constants $J$ were measured in Hertz. Infrared (IR) spectra were recorded on a Bruker TENSOR ${ }^{T M} 27$ (IRFT) and wave numbers are indicated in $\mathrm{cm}^{-1}$. Mass spectra with electronic impact (MS-EI) were recorded with a Shimadzu GCMS-QP 2010S (70 eV). High resolution mass spectra (HRMS) were performed at the Laboratoire de Spectrométrie de Masse de l'Université Pierre et Marie Curie de Paris using a TOF analyzer. $\mathrm{PE}=$ petroleum ether, $\mathrm{EA}=$ ethyl acetate.

\footnotetext{
${ }^{1}$ Love, B. E.; Jones, E. G. J. Org. Chem. 1999, 64, 3755-3756
} 


\section{I- Alkyl (pseudo)halides and Grignard reagents synthesis}

\section{General Procedure A:}

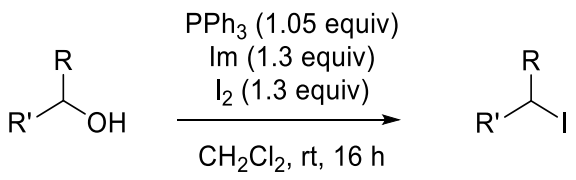

To a solution of alcohol (1 equiv) in $\mathrm{CH}_{2} \mathrm{Cl}_{2}$ at $\mathrm{rt}$ were added $\mathrm{PPh}_{3}$ (1.05 equiv) and imidazole (1.3 equiv). The mixture was cooled down to $0{ }^{\circ} \mathrm{C}$ and iodine (1.3 equiv) was added portionwise (4 to 5 portions). The round bottom flask was wrapped with aluminium foil and the reaction was allowed to warm to rt and stirred overnight. The reaction was quenched by addition of $\mathrm{H}_{2} \mathrm{O}$, the aqueous layer was extracted with $\mathrm{CH}_{2} \mathrm{Cl}_{2}$ (twice) and the combined organic layers were washed with an aqueous solution of sodium thiosulphate, dried over $\mathrm{MgSO}_{4}$, filtered and concentrated under reduced pressure. Purification by flash chromatography on silica gel (solid deposit) afforded the desired iodide.

\section{General Procedure B:}

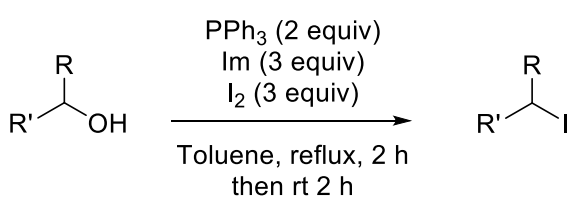

To a solution of alcohol (1 equiv) in toluene at $\mathrm{rt}$ were added $\mathrm{PPh}_{3}$ (2 equiv), imidazole ( 3 equiv) and iodide (3 equiv). The reaction was refluxed and stirred for $2 \mathrm{~h}$ before being cooled down to $\mathrm{rt}$ and stirred for another $2 \mathrm{~h}$. The reaction was quenched by the addition of $\mathrm{H}_{2} \mathrm{O}$, the aqueous layer was extracted with $\mathrm{CH}_{2} \mathrm{Cl}_{2}$ (twice) and the combined organic layers were washed with an aqueous solution of sodium thiosulphate, dried over $\mathrm{MgSO}_{4}$, filtered and concentrated under reduced pressure. Purification by flash chromatography on silica gel (solid deposit) afforded the desired iodide.

\section{General Procedure C:}

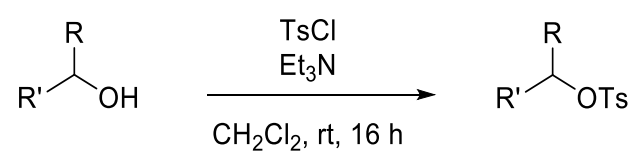

To a solution of alcohol (1 equiv) in $\mathrm{CH}_{2} \mathrm{Cl}_{2}$ at $0{ }^{\circ} \mathrm{C}$ were added $\mathrm{Et}_{3} \mathrm{~N}$ (1.05-2 equiv) and $\mathrm{TsCl}$ (1.05-4 equiv). The reaction was allowed to warm to $\mathrm{rt}$ and stirred overnight. After completion of the reaction, a saturated aqueous solution of $\mathrm{NH}_{4} \mathrm{Cl}$ was added and the aqueous layer was extracted with $\mathrm{CH}_{2} \mathrm{Cl}_{2}$ (twice). The combined organic phases were dried over $\mathrm{MgSO}_{4}$, filtered and concentrated under reduced pressure. Purification by flash chromatography on silica gel yielded the desired tosylate.

\section{General Procedure D:}

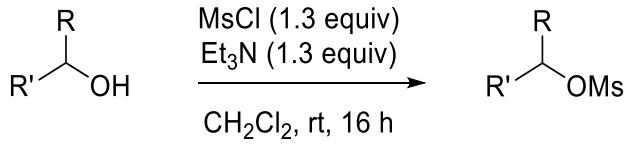

To a solution of alcohol (1 equiv) in $\mathrm{CH}_{2} \mathrm{Cl}_{2}$ at $0{ }^{\circ} \mathrm{C}$ were added $\mathrm{Et}_{3} \mathrm{~N}$ (1.3 equiv) and $\mathrm{MsCl}$ (1.3 equiv). The reaction was allowed to warm to rt and stirred overnight. After completion of the reaction, a saturated aqueous solution of $\mathrm{NH}_{4} \mathrm{Cl}$ was added and the aqueous layer was extracted with $\mathrm{CH}_{2} \mathrm{Cl}_{2}$ (twice). The combined organic phases were dried over $\mathrm{MgSO}_{4}$, filtered and concentrated under reduced pressure. Purification by flash chromatography on silica gel yielded the desired mesylate. 
I.1. Synthesis of primary alkyl halides

1-lodo-3-( $p$-methoxyphenyl) propane, $\mathbf{5} \mathbf{a}^{2}$<smiles>COc1ccc(CCCI)cc1</smiles>

lodide 5a was prepared according to Procedure A from 3-(p-methoxyphenyl)-1-propanol (S1) (3.50 g, $20.6 \mathrm{mmol})$. Purification by flash chromatography on silica gel $\left(\mathrm{PE} / \mathrm{Et}_{2} \mathrm{O}=90: 10\right)$ yielded iodide 5a $(5.48 \mathrm{~g}, 19.9 \mathrm{mmol}, 96 \%)$ as a colourless oil.

Formula: $\mathrm{C}_{10} \mathrm{H}_{13} \mathrm{Ol}$

Mass: $276.1 \mathrm{~g} \cdot \mathrm{mol}^{-1}$

IR (neat): $1611,1584,1511,1463,1441,1300,1245,1213,1177,1120,1101,1035 \mathrm{~cm}^{-1}$

${ }^{1} \mathrm{H}$ NMR $\left(400 \mathrm{MHz}, \mathrm{CDCl}_{3}\right) \delta 7.12(\mathrm{~d}, J=8.4 \mathrm{~Hz}, 2 \mathrm{H}), 6.84(\mathrm{~d}, J=8.5 \mathrm{~Hz}, 2 \mathrm{H}), 3.79(\mathrm{~s}, 3 \mathrm{H}), 3.16(\mathrm{t}$, $J=6.8 \mathrm{~Hz}, 2 \mathrm{H}$ ), $2.67(\mathrm{t}, J=7.2 \mathrm{~Hz}, 2 \mathrm{H}$ ), 2.10 (quint, $J=7.0 \mathrm{~Hz}, 2 \mathrm{H}$ )

${ }^{13} \mathrm{C}$ NMR $\left(100 \mathrm{MHz}, \mathrm{CDCl}_{3}\right) \delta 158.1,132.5,129.6(2 \mathrm{C}), 114.0(2 \mathrm{C}), 55.3,35.3,35.2,6.5$

MS (EI) m/z: 276 (32), 122 (9), 121 (100), 91 (6), 78 (7), 77 (8)

\section{I.2. Synthesis of primary sulfonic esters}

1-p-Tolyl-3-(p-methoxyphenyl)propanesulfonate $5 \mathbf{b}^{3}$<smiles>COc1ccc(CCCOS(=O)(=O)c2ccc(C)cc2)cc1</smiles>

Tosylate $\mathbf{5 b}$ was prepared according to Procedure $\mathbf{C}$ from 3-(p-methoxyphenyl)-1-propanol (S1) (700 $\mathrm{mg}, 4.21 \mathrm{mmol}, 1$ equiv), $\mathrm{Et}_{3} \mathrm{~N}$ (1.17 mL, $8.42 \mathrm{mmol}, 2$ equiv) and $\mathrm{TsCl}$ (963 mg, $5.05 \mathrm{mmol}, 1.2$ equiv). Purification by flash chromatography on silica gel (gradient of elution $\mathrm{PE} / \mathrm{Et}_{2} \mathrm{O}=93: 7$ to $50: 50$ ) yielded tosylate $5 \mathrm{~b}(1.22 \mathrm{~g}, 3.82 \mathrm{mmol}, 91 \%)$ as a white solid. ${ }^{4}$

Formula: $\mathrm{C}_{17} \mathrm{H}_{20} \mathrm{O}_{4} \mathrm{~S}$

Mass: $320.4 \mathrm{~g} \cdot \mathrm{mol}^{-1}$

mp: $35-37^{\circ} \mathrm{C}$

IR (neat) 2958, 1612, 1598, 1584, 1559, 1511, 1455, 1355, 1300, 1245, 1211, 1188, 1173, 1097, 1034, $1000,965,923 \mathrm{~cm}^{-1}$

${ }^{1} \mathrm{H}$ NMR $\left(400 \mathrm{MHz}, \mathrm{CDCl}_{3}\right) \delta 7.79(\mathrm{~d}, J=8.3 \mathrm{~Hz}, 2 \mathrm{H}), 7.34(\mathrm{~d}, J=8.0 \mathrm{~Hz}, 2 \mathrm{H}), 6.98(\mathrm{~d}, J=8.7 \mathrm{~Hz}, 2 \mathrm{H})$, $6.78(\mathrm{~d}, J=8.7 \mathrm{~Hz}, 2 \mathrm{H}), 4.02(\mathrm{t}, J=6.2 \mathrm{~Hz}, 2 \mathrm{H}), 3.77(\mathrm{~s}, 3 \mathrm{H}), 2.59(\mathrm{t}, J=7.5 \mathrm{~Hz}, 2 \mathrm{H}), 2.46(\mathrm{~s}, 3 \mathrm{H})$, $1.96-1.87(\mathrm{~m}, 2 \mathrm{H})$

${ }^{13} \mathrm{C}$ NMR $\left(100 \mathrm{MHz}, \mathrm{CDCl}_{3}\right) \delta 158.0,144.8,133.2,132.4,129.9(2 \mathrm{C}), 129.4(2 \mathrm{C}), 128.0(2 \mathrm{C}), 113.9$ (2C), 69.7, 55.3, 30.7, 30.6, 21.7

Methyl 3-(p-methoxyphenyl)propanesulfonate, $\mathbf{5 c ^ { 5 }}$<smiles>COc1ccc(CCCOS(C)(=O)=O)cc1</smiles>

\footnotetext{
${ }^{2}$ Rezazadeh, S.; Devannah, V.; Watson, D. A. J. Am. Chem. Soc. 2017, 139, 8110-8113.

${ }^{3}$ Comagic, S.; Schirrmacher, R. Synthesis, 2004, 6, 885-888.

${ }^{4}$ No MS spectra is disclosed due to degradation.

${ }^{5}$ Kuo, F.; Clodfelter, D. K.; Farid, N. A.; Wheeler, W. J.; McKendry, L. H. Journal of Labelled Compounds and Radiopharmaceuticals 2007, 50, 693-701.
} 
Mesylate 5c was prepared according to Procedure D from 3-(p-methoxyphenyl)-1-propanol (S1) (400 $\mathrm{mg}, 2.41 \mathrm{mmol}, 1$ equiv). Purification by flash chromatography on silica gel (gradient of elution $\mathrm{PE} / \mathrm{Et}_{2} \mathrm{O}=93: 7$ to $\left.50: 50\right)$ yielded mesylate $5 \mathrm{c}(571 \mathrm{mg}, 0.34 \mathrm{mmol}, 97 \%)$ as a white solid.

Formula: $\mathrm{C}_{11} \mathrm{H}_{16} \mathrm{O}_{4} \mathrm{~S}$

Mass: $244.3 \mathrm{~g} \cdot \mathrm{mol}^{-1}$

mp: $41-44{ }^{\circ} \mathrm{C}$

IR (neat): 1612, 1584, 1512, 1466, 1419, 1349, 1332, 1301, 1244, 1169, 1113, 1032, 1004, 972, 957, $921 \mathrm{~cm}^{-1}$

${ }^{1} \mathrm{H}$ NMR $\left(400 \mathrm{MHz}, \mathrm{CDCl}_{3}\right) \delta 7.10(\mathrm{~d}, J=8.6 \mathrm{~Hz}, 2 \mathrm{H}), 6.84(\mathrm{~d}, J=8.5 \mathrm{~Hz}, 2 \mathrm{H}), 4.21(\mathrm{t}, J=6.3 \mathrm{~Hz}, 2 \mathrm{H})$, $3.79(\mathrm{~s}, 3 \mathrm{H}), 2.99(\mathrm{~s}, 3 \mathrm{H}), 2.69(\mathrm{t}, J=7.5 \mathrm{~Hz}, 2 \mathrm{H}), 2.10-1.95(\mathrm{~m}, 2 \mathrm{H})$

${ }^{13} \mathrm{C}$ NMR $\left(100 \mathrm{MHz}, \mathrm{CDCl}_{3}\right) \delta 158.1,132.3,129.4(2 \mathrm{C}), 114.0(2 \mathrm{C}), 69.3,55.3,37.4,30.9,30.6$

MS (EI) m/z: 244 (26), 149 (6), 148 (41), 147 (32), 133 (9), 122 (9), 121 (100), 117 (14), 105 (6), 91 (11), 79 (7), 78 (6), 77 (10), 65 (5)

Methyl 4-(benzyloxy)butanesulfonate, $\mathbf{5} \mathbf{d}^{6}$

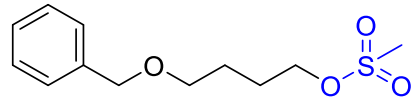

Mesylate 5d was prepared according to Procedure D from 4-(benzyloxy)butan-1-ol (S2) (400 mg, 2.22 $\mathrm{mmol})$. Purification on a plug of silica gel $\left(\mathrm{PE} / \mathrm{Et}_{2} \mathrm{O}=60: 40\right)$ yielded mesylate $\mathbf{5 d}(558 \mathrm{mg}, 2.16 \mathrm{mmol}$, 97\%) as a colourless oil.

Formula: $\mathrm{C}_{12} \mathrm{H}_{18} \mathrm{O}_{4} \mathrm{~S}$

Mass: $258.3 \mathrm{~g} \cdot \mathrm{mol}^{-1}$

IR (neat): 1496, 1454, 1408, 1394, 1350, 1250, 1205, 1171, 1078, 1054, 1028, 972, $934 \mathrm{~cm}^{-1}$

${ }^{1} \mathrm{H}$ NMR $\left(400 \mathrm{MHz}, \mathrm{CDCl}_{3}\right) \delta 7.44-7.22(\mathrm{~m}, 5 \mathrm{H}), 4.52(\mathrm{~s}, 2 \mathrm{H}), 4.28(\mathrm{t}, J=6.4 \mathrm{~Hz}, 2 \mathrm{H}), 3.54(\mathrm{t}, J=$ $6.1 \mathrm{~Hz}, 2 \mathrm{H}), 3.00(\mathrm{~s}, 3 \mathrm{H}), 1.97-1.83(\mathrm{~m}, 2 \mathrm{H}), 1.81-1.68(\mathrm{~m}, 2 \mathrm{H})$

${ }^{13} \mathrm{C}$ NMR $\left(100 \mathrm{MHz}, \mathrm{CDCl}_{3}\right) \delta 138.4,128.5$ (2C), 127.7 (3C), 73.1, 70.0, 69.4, 37.4, 26.3, 25.8

MS (EI) m/z: 258 (1), 161 (15), 107 (50), 105 (11), 92 (16), 91 (100), 79 (20), 71 (11), 65 (14), 56 (14), $55(17)$

Methyl (3,4-dihydro-2H-pyran-2-yl)methanesulfonate, $5 \mathbf{e}^{7}$<smiles>CS(=O)(=O)OCC1CCC=CO1</smiles>

Mesylate 5e was prepared according to Procedure D from (3,4-dihydro-2H-pyran-2-yl)methanol (S3) (250 mg, $2.19 \mathrm{mmol}, 1$ equiv) at $0{ }^{\circ} \mathrm{C}$ for $6 \mathrm{~h}$. Purification by flash chromatography on silica gel (gradient of elution $\mathrm{PE} / \mathrm{EA}=90: 10$ to $80: 20)$ yielded mesylate $5 \mathrm{e}(104 \mathrm{mg}, 0.54 \mathrm{mmol}, 25 \%)$ as a colourless oil.

Formula: $\mathrm{C}_{7} \mathrm{H}_{12} \mathrm{O}_{4} \mathrm{~S}$

Mass: $192.2 \mathrm{~g} \cdot \mathrm{mol}^{-1}$

IR (neat): 1650, 1452, 1349, 1265, 1240, 1170, 1114, 1067, 1040, 953, $937 \mathrm{~cm}^{-1}$

${ }^{1} \mathrm{H}$ NMR $\left(400 \mathrm{MHz}, \mathrm{CDCl}_{3}\right) \delta 6.36\left(\mathrm{br} \mathrm{dt}, J=6.2,1.8 \mathrm{~Hz}, 1 \mathrm{H}, \mathrm{H}_{1}\right), 4.74\left(\mathrm{~m}, 1 \mathrm{H}, \mathrm{H}_{2}\right), 4.31(\mathrm{~d}, J=1.6 \mathrm{~Hz}$, $\left.1 \mathrm{H}, \mathrm{H}_{6}\right), 4.29\left(\mathrm{~d}, J=2.8 \mathrm{~Hz}, 1 \mathrm{H}, \mathrm{H}_{6^{\prime}}\right), 4.10(\mathrm{~m}, 1 \mathrm{H}), 3.06(\mathrm{~s}, 3 \mathrm{H}), 2.13(\mathrm{~m}, 1 \mathrm{H}), 2.00(\mathrm{~m}, 1 \mathrm{H}), 1.86(\mathrm{~m}$, $1 \mathrm{H}), 1.72(\mathrm{~m}, 1 \mathrm{H})$

${ }^{13} \mathrm{C}$ NMR $\left(100 \mathrm{MHz}, \mathrm{CDCl}_{3}\right) \delta 143.0,101.0,72.4,71.2,37.8,23.8,19.0$

\footnotetext{
${ }^{6}$ LaFrate, A. L.; Carlson, K. E.; Katzenellenbogen, J. A. Bioorganic \& Medicinal Chemistry 2009, 17, 3528-3535.

${ }^{7}$ Schenkel, L. B.; Vasbinder, M. M.; Kuntz, K. W.; Swinger, K. K. Quinazolinones as Parp14 Inhibitors. US2019194174 (A1), June $27,2019$.
} 
MS (EI) m/z: 192 (28), 96 (63), 95 (99), 83 (94), 81 (92), 79 (43), 68 (55), 67 (87), 66 (23), 65 (18), 57 (55), 55 (100), 54 (18), 53 (23)

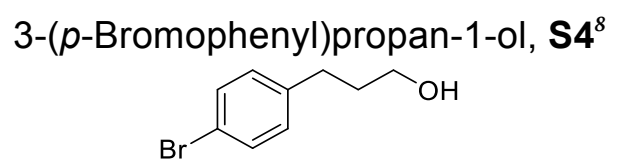

To a solution of 3-(p-bromophenyl)propanoic acid $\mathbf{S 5}$ (500 $\mathrm{mg}, 2.18 \mathrm{mmol}, 1$ equiv) in THF (22 $\mathrm{mL})$ at $0{ }^{\circ} \mathrm{C}$ was added dropwise a solution of $\mathrm{BH}_{3} \bullet \mathrm{THF}(1 \mathrm{M}$ in THF, $4.37 \mathrm{~mL}, 4.36 \mathrm{mmol}, 2$ equiv). The reaction mixture was allowed to warm up to $\mathrm{rt}$ and was stirred for $2 \mathrm{~h}$ before being quenched by a $1: 1$ solution of Rochelle salts/saturated aqueous solution of $\mathrm{NaHCO}_{3}$. The aqueous phase was extracted with $\mathrm{Et}_{2} \mathrm{O}$. The combined organic phases were washed with brine, dried over $\mathrm{MgSO}_{4}$, filtered and concentrated under reduced pressure. Purification by flash chromatography on silica gel (gradient of elution PE/Et ${ }_{2} \mathrm{O}=70: 30$ to $\left.50: 50\right)$ yielded alcohol $\mathbf{S 4}(467 \mathrm{mg}, 2.17 \mathrm{mmol}, 99 \%)$ as a colourless oil.

Formula: $\mathrm{C}_{9} \mathrm{H}_{11} \mathrm{BrO}$

Mass: $215.1 \mathrm{~g} \cdot \mathrm{mol}^{-1}$

IR (neat): 3310, 1487, 1452, 1404, 1070, 1040, 1010, $913 \mathrm{~cm}^{-1}$

${ }^{1} \mathrm{H}$ NMR $\left(400 \mathrm{MHz}, \mathrm{CDCl}_{3}\right) \delta 7.40(\mathrm{~d}, J=8.4 \mathrm{~Hz}, 2 \mathrm{H}), 7.07(\mathrm{~d}, J=8.3 \mathrm{~Hz}, 2 \mathrm{H}), 3.66(\mathrm{t}, J=6.4 \mathrm{~Hz}, 2 \mathrm{H})$, $2.66(\mathrm{t}, J=7.8 \mathrm{~Hz}, 2 \mathrm{H}), 1.90-1.81(\mathrm{~m}, 2 \mathrm{H}), 1.49(\mathrm{~m}, 1 \mathrm{H})$

${ }^{13} \mathrm{C}$ NMR $\left(100 \mathrm{MHz}, \mathrm{CDCl}_{3}\right) \delta 140.8,131.5(2 \mathrm{C}), 130.3(2 \mathrm{C}), 119.6,62.0,34.1,31.5$

MS (EI) m/z: 216 (20), 214 (20), 205 (9), 198 (26), 196 (27), 171 (27), 169 (30), 118 (10), $117(100)$, 115 (23), 104 (19), 103 (12), 91 (38), 90 (25), 89 (18), 78 (10), 77 (20), 63 (10), 51 (12), 50 (7)

Methyl 3-(p-bromophenyl)propanesulfonate, $\mathbf{5 f}^{9}$<smiles>CS(=O)(=O)OCCCc1ccc(Br)cc1</smiles>

Mesylate $\mathbf{5 f}$ was prepared according to Procedure $\mathbf{D}$ from 3-(p-bromophenyl)propan-1-ol (S4) (400 mg, $1.86 \mathrm{mmol})$. Filtration over a plug of silica gel $\left(\mathrm{PE} / \mathrm{Et}_{2} \mathrm{O}=40: 60\right)$ yielded mesylate $5 \mathrm{f}(554 \mathrm{mg}, 1.86$ mmol, quant.) as a colourless solid.

Formula: $\mathrm{C}_{10} \mathrm{H}_{13} \mathrm{BrO}_{3} \mathrm{~S}$

Mass: $293.2{\mathrm{~g} . \mathrm{mol}^{-1}}^{-1}$

mp: $34-35^{\circ} \mathrm{C}$

IR (neat): $1597,1488,1406,1348,1170,1094,1072,1010,971,956,924 \mathrm{~cm}^{-1}$

${ }^{1} \mathrm{H}$ NMR $\left(400 \mathrm{MHz}, \mathrm{CDCl}_{3}\right) \delta 7.42(\mathrm{~d}, J=8.4 \mathrm{~Hz}, 2 \mathrm{H}), 7.07(\mathrm{~d}, J=8.5 \mathrm{~Hz}, 2 \mathrm{H}), 4.22(\mathrm{t}, J=6.3 \mathrm{~Hz}, 2 \mathrm{H})$, $3.00(\mathrm{~s}, 3 \mathrm{H}), 2.71(\mathrm{t}, J=7.6 \mathrm{~Hz}, 2 \mathrm{H}), 2.05(\mathrm{~m}, 2 \mathrm{H})$

${ }^{13} \mathrm{C}$ NMR $\left(100 \mathrm{MHz}, \mathrm{CDCl}_{3}\right) \delta 139.3,131.7$ (2C), $130.3(2 \mathrm{C}), 120.2,68.9,37.5,31.1,30.6$

MS (EI) m/z: 295 (1), 294 (4), 293 (1), 292 (3), 198 (34), 196 (35), 171 (15), 169 (14), 118 (11), 117 (100), 116 (11), 115 (28), 104 (9), 91 (13), 90 (14), 89 (11), 77 (10)

Methyl 6-(methanesulfonyloxy)hexanoate, $\mathbf{5 g}$<smiles>COC(=O)CCCCCOS(C)(C)O</smiles>

\footnotetext{
${ }^{8}$ Pettit, G. R.; Quistorf, P. D.; Fry, J. A.; Herald, D. L.; Hamel, E.; Chapuis, J.-C. J. Nat. Prod. 2009, 72, 876-883.

${ }^{9}$ Kim, Y. K.; Park, S. Y.; Joo, H. W.; Choi, E. S.; Paek, S. Y.; Kang, S. W.; Kim, B. G.; Lee, C. S.; Kim, S. W.; Lee, S. D. Biaryl Derivative as Gpr120 Agonist. EP3239143 (A2), November 1, 2017.
} 
Intermediate methyl 6-hydroxyhexanoate (S6) was prepared from $\varepsilon$-caprolactone (S7) (700 mg, $6.13 \mathrm{mmol}, 1$ equiv) in refluxing $\mathrm{MeOH}(12 \mathrm{~mL})$ for $4 \mathrm{~h}$ in the presence of $\mathrm{K}_{2} \mathrm{CO}_{3}(848 \mathrm{mg}, 6.13 \mathrm{mmol}$, 1 equiv) followed by stirring at $\mathrm{rt}$ overnight. The reaction mixture was concentrated under reduced pressure before being dissolved in $\mathrm{CH}_{2} \mathrm{Cl}_{2}$. The organic phase was washed with $\mathrm{H}_{2} \mathrm{O}$ and brine successively, dried over $\mathrm{MgSO}_{4}$, filtered and concentrated under reduced pressure. Alcohol $\mathbf{S 6}$ was obtained as a colourless liquid (186 $\mathrm{mg}, 1.13 \mathrm{mmol}, 21 \%$ ) and was used in the next step without any further purification. Mesylate $\mathbf{5 g}$ was prepared according to Procedure $\mathbf{D}$ from methyl 6-hydroxyhexanoate (S6) (185 $\mathrm{mg}, 1.27 \mathrm{mmol}$ ) in $2 \mathrm{~h}$. Purification by flash chromatography on silica gel (PE to PE/EA = 75:25) yielded mesylate $\mathbf{5 g}(238 \mathrm{mg}, 1.06 \mathrm{mmol}, 84 \%)$ as a colourless oil.

Formula: $\mathrm{C}_{8} \mathrm{H}_{16} \mathrm{O}_{5} \mathrm{~S}$

Mass: $224.3 \mathrm{~g} \cdot \mathrm{mol}^{-1}$

IR (neat): 1731, 1438, 1349, 1197, 1170, 1101, 1009, 974, 942, $909 \mathrm{~cm}^{-1}$

${ }^{1} \mathrm{H}$ NMR $\left(400 \mathrm{MHz}, \mathrm{CDCl}_{3}\right) \delta 4.22(\mathrm{t}, J=6.5 \mathrm{~Hz}, 2 \mathrm{H}), 3.67(\mathrm{~s}, 3 \mathrm{H}), 3.00(\mathrm{~s}, 3 \mathrm{H}), 2.33(\mathrm{t}, J=7.4 \mathrm{~Hz}, 2 \mathrm{H})$, $1.82-1.73(\mathrm{~m}, 2 \mathrm{H}), 1.71-1.61(\mathrm{~m}, 2 \mathrm{H}), 1.52-1.39(\mathrm{~m}, 2 \mathrm{H})$

${ }^{13} \mathrm{C}$ NMR $\left(100 \mathrm{MHz}, \mathrm{CDCl}_{3}\right) \delta 173.9,69.8,51.7,37.5,33.8,28.9,25.1,24.4$

MS (EI) m/z: 193 (13), 128 (17), 113 (24), 100 (12), 97 (24), 96 (14), 87 (19), 79 (32), 74 (100), 69 (61), 68 (87), 67 (20), 59 (33), 55 (92), 54 (11)

\section{I.3. Synthesis of secondary alkyl halides}

\section{I.3.1. Synthesis of cyclic secondary alkyl (pseudo)halides}

\section{- Appel reaction}

N-Boc-4-(methanesulfonyloxy)piperidine, $\mathbf{5 i}$<smiles>CC(C)(C)OC(=O)N1CCC(OS(C)(=O)=O)CC1</smiles>

Mesylate 5i was prepared according to a modified Procedure $\mathbf{D}$ from $\mathrm{N}$-Boc-4-hydroxypiperidine 10 (5.40 g, 26.8 mmol, 1 equiv), $\mathrm{Et}_{3} \mathrm{~N}$ (5.22 mL, $37.6 \mathrm{mmol}, 1.4$ equiv) and $\mathrm{MsCl}(2.91 \mathrm{~mL}, 37.6 \mathrm{mmol}$, 1.4 equiv). No purification was necessary to yield mesylate $5 \mathbf{i}(7.10 \mathrm{~g}, 25.4 \mathrm{mmol}, 95 \%)$ as a white solid. $^{10}$

Formula: $\mathrm{C}_{11} \mathrm{H}_{21} \mathrm{NO}_{5} \mathrm{~S}$

Mass: $279.4 \mathrm{~g} \cdot \mathrm{mol}^{-1}$

${ }^{1} \mathrm{H}$ NMR $\left(400 \mathrm{MHz}, \mathrm{CDCl}_{3}\right) \delta 4.87$ (hept, $\left.J=3.8 \mathrm{~Hz}, 1 \mathrm{H}\right), 3.75-3.57(\mathrm{~m}, 2 \mathrm{H}), 3.29$ (ddd, $J=13.7,8.1$, $3.8 \mathrm{~Hz}, 2 \mathrm{H}), 3.03(\mathrm{~s}, 3 \mathrm{H}), 2.00-1.89(\mathrm{~m}, 2 \mathrm{H}), 1.80(\mathrm{~m}, 2 \mathrm{H}), 1.45(\mathrm{~s}, 9 \mathrm{H})$

MS (EI) m/z: 222 (3), 128 (15), 127 (21), 126 (7), 110 (10), 84 (23), 83 (20), 82 (10), 68 (7), 57 (100), $56(9), 55(9)$

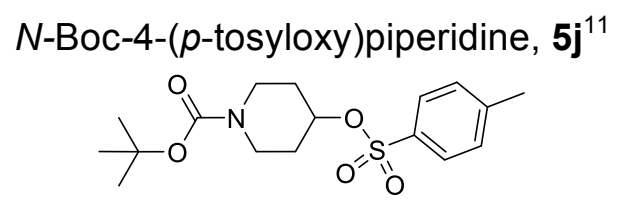

Tosylate 5j was prepared according to Procedure C from N-Boc-4-hydroxypiperidine (10) (600 mg, $2.98 \mathrm{mmol}, 1$ equiv), $\mathrm{Et}_{3} \mathrm{~N}$ (1.66 mL, $11.9 \mathrm{mmol}, 2$ equiv) and $\mathrm{TsCl}(1.14 \mathrm{~g}, 5.96 \mathrm{mmol}, 4$ equiv).

\footnotetext{
${ }^{10}$ The ${ }^{13} \mathrm{C}$ NMR has not been recorded.

${ }^{11}$ He, F.; Du-Cuny, L.; Xiao, Q.; Xun, G.; Zheng, Q. Cyano-Substituted Indole Compounds and Uses Thereof as Lsd1 Inhibitors. WO2017149463 (A1), September 8, 2017.
} 
Purification by flash chromatography on silica gel (gradient of elution PE/EA $=95: 5$ to $60: 40$ ) yielded tosylate $5 \mathbf{j}$ ( $868 \mathrm{mg}, 2.44 \mathrm{mmol}, 82 \%)$ as a yellow solid.

Formula: $\mathrm{C}_{17} \mathrm{H}_{25} \mathrm{NO}_{5} \mathrm{~S}$

Mass: $355.5 \mathrm{~g} \cdot \mathrm{mol}^{-1}$

mp: $92-95^{\circ} \mathrm{C}$

IR (neat): 1687, 1598, 1477, 1454, 1421, 1364, 1320, 1275, 1237, 1188, 1172, 1123, 1097, 1069, 1011, $943,908 \mathrm{~cm}^{-1}$

${ }^{1} \mathrm{H}$ NMR $\left(400 \mathrm{MHz}, \mathrm{CDCl}_{3}\right) \delta 7.79(\mathrm{~d}, J=8.3 \mathrm{~Hz}, 2 \mathrm{H}), 7.34(\mathrm{~d}, J=8.4 \mathrm{~Hz}, 2 \mathrm{H}), 4.67(\mathrm{~m}, 1 \mathrm{H}), 3.65-3.52$ $(\mathrm{m}, 2 \mathrm{H}), 3.24\left(\mathrm{ddd}, \mathrm{J}_{\mathrm{AB}}=13.6,7.6,4.0 \mathrm{~Hz}, 2 \mathrm{H}\right), 2.45(\mathrm{~s}, 3 \mathrm{H}), 1.81-1.62(\mathrm{~m}, 4 \mathrm{H}), 1.43(\mathrm{~s}, 9 \mathrm{H})$

${ }^{13} \mathrm{C}$ NMR $\left(100 \mathrm{MHz}, \mathrm{CDCl}_{3}\right) \delta 154.6,144.8,134.4,130.0$ (2C), 127.7 (2C), 80.0, 78.1, 40.5 (2C), 31.3 (2C), $28.4(3 \mathrm{C}), 21.7$

MS (EI) m/z: 355 (1), 183 (12), 128 (8), 127 (64), 126 (13), 118 (38), 100 (25), 84 (13), 83 (60), 82 (77), 72 (12), 68 (24), 58 (8), 57 (100), 55 (11)

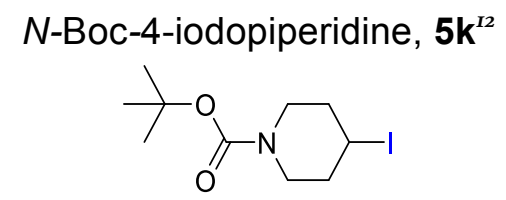

To a solution of 4-hydroxypiperidine (S8) (350 mg, 3.39 mmol, 1 equiv) in $\mathrm{CH}_{2} \mathrm{Cl}_{2}$ (9 mL) was added an aqueous solution of $\mathrm{Na}_{2} \mathrm{CO}_{3}$ (755 mg, $7.12 \mathrm{mmol}, 2.1$ equiv in $12 \mathrm{~mL} \mathrm{H}$ O) followed by $\mathrm{Boc}_{2} \mathrm{O}(0.81 \mathrm{~mL}$, $3.72 \mathrm{mmol}, 1.1$ equiv). The reaction mixture was stirred overnight at $\mathrm{rt}$ before separating the layers. The aqueous layer was extracted with $\mathrm{CH}_{2} \mathrm{Cl}_{2}$ and the combined organic layers were dried over $\mathrm{MgSO}_{4}$, filtered and concentrated under vacuum. The crude mixture of $\mathrm{N}$-Boc-4-hydroxypiperidine 10 was engaged in the next step. lodide 5k was prepared according to Procedure $\mathbf{A}$ from $\mathrm{N}$-Boc-4hydroxypiperidine $10(2.9 \mathrm{~g})$. Purification by flash chromatography on silica gel (gradient of elution $\mathrm{PE} / \mathrm{Et}_{2} \mathrm{O}=95: 5$ to $\left.90: 10\right)$ yielded iodide $5 \mathbf{k}(2.50 \mathrm{~g}, 8.19 \mathrm{mmol}, 56 \%)$ as an off-white solid.

Formula: $\mathrm{C}_{10} \mathrm{H}_{18} \mathrm{NO}_{2} \mathrm{I}$

Mass: $311.2 \mathrm{~g} \cdot \mathrm{mol}^{-1}$

mp: $46-49{ }^{\circ} \mathrm{C}$

IR (neat): 1687, 1476, 1464, 1446, 1415, 1365, 1331, 1274, 1233, 1153, 1100, 1008, 994, $932 \mathrm{~cm}^{-1}$

${ }^{1} \mathrm{H}$ NMR $\left(400 \mathrm{MHz}, \mathrm{CDCl}_{3}\right) \delta 4.44$ (quint $_{\mathrm{app}}, J=6.0 \mathrm{~Hz}, 1 \mathrm{H}$ ), $3.58(\mathrm{br} \mathrm{dt}, J=13.3,5.0 \mathrm{~Hz}, 2 \mathrm{H}$ ), 3.27 (dt, $J=13.7,5.9 \mathrm{~Hz}, 2 \mathrm{H}), 2.02(\mathrm{br} \mathrm{q}$ app, $J=5.8 \mathrm{~Hz}, 4 \mathrm{H}), 1.45(\mathrm{~s}, 9 \mathrm{H})$

${ }^{13} \mathrm{C}$ NMR $\left(100 \mathrm{MHz}, \mathrm{CDCl}_{3}\right) \delta 154.8,79.9,44.0(2 \mathrm{C}), 37.4(2 \mathrm{C}), 28.5(3 \mathrm{C}), 27.8$

MS (EI) m/z: 311 (1), 256 (4), 238 (8), 184 (21), 128 (33), 84 (29), 67 (4), 58 (4), 57 (100), 56 (11), 55 (10)

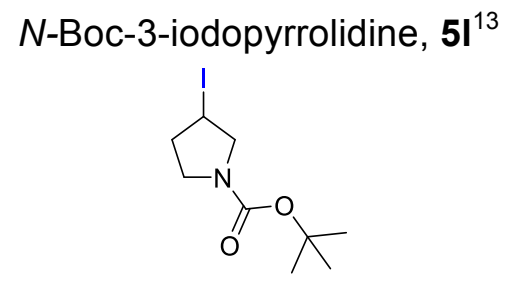

lodide 5I was prepared according to Procedure B from N-Boc-3-hydroxypyrrolidine (S9) (600 mg). Purification by flash chromatography on silica gel (PE/Et $\mathrm{t}_{2} \mathrm{O} 95: 5$ to $80: 20$ ) yielded iodide $\mathbf{5 I}$ as a mixture of rotamers in a $73: 27$ ratio $(706 \mathrm{mg}, 2.37 \mathrm{mmol}, 74 \%)$ as a colourless oil.

\footnotetext{
${ }^{12}$ Kulbitski, K.; Nisnevich, G.; Gandelman, M. Adv. Synth. Catal. 2011, 353, 1438-1442.

${ }^{13}$ Guisán-Ceinos, M.; Soler-Yanes, R.; Collado-Sanz, D.; Phapale, V. B.; Buñuel, E.; Cárdenas, D. J. Chem. Eur. J. 2013, 19, 8405-8410.
} 
Formula: $\mathrm{C}_{9} \mathrm{H}_{16} \mathrm{O}_{2} \mathrm{I}$

Mass: $297.1 \mathrm{~g} \cdot \mathrm{mol}^{-1}$

IR (neat): 1689, 1477, 1454, 1394, 1365, 1346, 1295, 1257, 1222, 1156, 1108, 977, 929, $916 \mathrm{~cm}^{-1}$

${ }^{1} \mathrm{H}$ NMR $\left(400 \mathrm{MHz}, \mathrm{CDCl}_{3}\right) \delta 4.35(\mathrm{~m}, 1 \mathrm{H}), 3.89-3.72(\mathrm{~m}, 1.46 \mathrm{H}), 3.67(\mathrm{~m}, 0.54 \mathrm{H}), 3.57(\mathrm{~m}, 1 \mathrm{H}), 3.42$ $(\mathrm{m}, 1 \mathrm{H}), 2.32-2.15(\mathrm{~m}, 2 \mathrm{H}), 1.45(\mathrm{~s}, 9 \mathrm{H})$

${ }^{13} \mathrm{C}$ NMR $\left(100 \mathrm{MHz}, \mathrm{CDCl}_{3}\right) \delta[154.3,154.2],[79.82,79.76],[57.4,57.1],[45.1,44.8],[38.4,37.7], 28.5$ (3C), 20.0

MS (EI) m/z: 297 (2), 242 (23), 224 (8), 197 (7), 70 (17), 68 (6), 58 (5), 57 (100), 56 (10)

$N$-Boc-3-(p-tosyloxy)pyrrolidine, $\mathbf{5 m}^{14}$

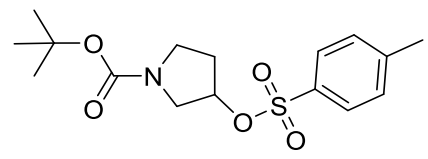

Tosylate $\mathbf{5 m}$ was prepared according to Procedure C from N-Boc-3-hydroxypyrrolidine (S9) (700 mg, $3.55 \mathrm{mmol}, 1$ equiv), $\mathrm{Et}_{3} \mathrm{~N}$ (0.99 mL, $7.10 \mathrm{mmol}, 2$ equiv) and $\mathrm{TsCl}$ (1.35 g, $7.10 \mathrm{mmol}, 2$ equiv). Purification by flash chromatography on silica gel $(P E / E A=60: 40)$ yielded tosylate $5 \mathrm{~m}(451 \mathrm{mg}$, $1.32 \mathrm{mmol}, 37 \%$ ) as a $1: 1$ mixture of two rotamers as a white solid.

Formula: $\mathrm{C}_{16} \mathrm{H}_{23} \mathrm{NO}_{5} \mathrm{~S}$

Mass: $341.4 \mathrm{~g} \cdot \mathrm{mol}^{-1}$

mp: $74-78{ }^{\circ} \mathrm{C}$

IR (neat): 2976, 2884, 1692, 1597, 1518, 1478, 1455, 1401, 1363, 1306, 1257, 1231, 1212, 1188, 1172, $1114,1100,1085,1053,1012,988,956,922 \mathrm{~cm}^{-1}$

${ }^{1} \mathrm{H}$ NMR $\left(400 \mathrm{MHz}, \mathrm{CDCl}_{3}\right) \delta 7.79(\mathrm{~d}, J=7.9 \mathrm{~Hz}, 2 \mathrm{H}), 7.35(\mathrm{~d}, J=7.6 \mathrm{~Hz}, 2 \mathrm{H}), 5.03\left(\mathrm{br} \mathrm{s} \mathrm{s}_{\mathrm{app}}, 1 \mathrm{H}\right), 3.58-$ $3.32(\mathrm{~m}, 4 \mathrm{H}), 2.45(\mathrm{~s}, 3 \mathrm{H}), 2.23-1.89(\mathrm{~m}, 2 \mathrm{H}), 1.42(\mathrm{~s}, 9 \mathrm{H})$

${ }^{13} \mathrm{C}$ NMR $\left(100 \mathrm{MHz}, \mathrm{CDCl}_{3}\right) \delta 154.1,145.1,134.0,130.1$ (2C), 127.8 (2C), [80.8, 80.1], 79.8, [51.9, 51.5], [43.7, 43.3], [32.5, 31.4], 28.5 (3C), 21.7

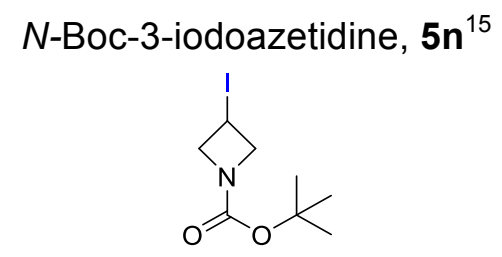

lodide 5n was prepared according to Procedure B from N-Boc-3-hydroxyazetidine (S10) (1.0 g). Purification by flash chromatography on silica gel $\left(\mathrm{PE} / \mathrm{Et}_{2} \mathrm{O}=80: 20\right)$ yielded iodide $\mathbf{5 n}(1.60 \mathrm{~g}, 5.60$ mmol, $100 \%$ ) as a colourless oil.

Formula: $\mathrm{C}_{8} \mathrm{H}_{14} \mathrm{NO}_{2} \mathrm{I}$

Mass: $283.1 \mathrm{~g} \cdot \mathrm{mol}^{-1}$

IR (neat): 1696, 1536, 1477, 1456, 1381, 1365, 1302, 1254, 1201, 1145, 1140, 1032, 969, $886 \mathrm{~cm}^{-1}$

${ }^{1} \mathrm{H}$ NMR $\left(400 \mathrm{MHz}, \mathrm{CDCl}_{3}\right) \delta 4.66-4.60(\mathrm{~m}, 2 \mathrm{H}), 4.45(\mathrm{~m}, 1 \mathrm{H}), 4.31-4.23(\mathrm{~m}, 2 \mathrm{H}), 1.42(\mathrm{~s}, 9 \mathrm{H})$

${ }^{13} \mathrm{C}$ NMR $\left(100 \mathrm{MHz}, \mathrm{CDCl}_{3}\right) \delta 155.6,80.2,61.6(2 \mathrm{C}), 28.4(3 \mathrm{C}), 2.7$

MS (EI) m/z: 283 (1), 228 (6), 183 (7), 156 (5), 82 (10), 58 (4), 57 (100), 56 (24), 55 (4), 54 (4)

$$
\text { N-Boc-4-bromopiperidine-, } 5 \mathbf{q}^{16}
$$

\footnotetext{
${ }^{14}$ Gao, Z.; Hall, D.; Stefany, D.; WO2011/143148, 2011, A1. SANOFI.

${ }^{15}$ Barré, B.; Gonnard, L.; Campagne, R.; Reymond, S.; Marin, J.; Ciapetti, P.; Brellier, M.; Guérinot, A.; Cossy, J. Org. Lett. 2014, 16, 61606163.

${ }^{16}$ Gonnard, L.; Guérinot, A.; Cossy, J. Chem. Eur. J. 2015, 21, 12797-12803.
} 


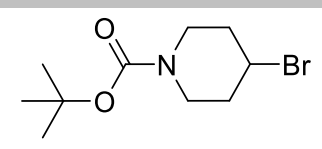

To a solution of $\mathrm{N}$-Boc-4-hydroxypiperidine (10) (1.40 g, $6.96 \mathrm{mmol}, 1$ equiv) and $\mathrm{PPh}_{3}(1.96 \mathrm{~g}, 7.30$ mmol, 1.05 equiv) in $\mathrm{CH}_{2} \mathrm{Cl}_{2}(35 \mathrm{~mL})$ at rt was added $\mathrm{CBr}_{4}(3.06 \mathrm{~g}, 9.04 \mathrm{mmol}, 1.3$ equiv). The reaction was stirred and, after $4 \mathrm{~h}$ at $\mathrm{rt}$, the solvent was evaporated. Purification by flash chromatography on silica gel (gradient of elution PE/EA $=95: 5$ to $70: 30$ ) yielded bromine $\mathbf{5 q}(343 \mathrm{mg}, 1.30 \mathrm{mmol}, 19 \%$ ) as an orange oil.

Formula: $\mathrm{C}_{10} \mathrm{H}_{18} \mathrm{BrNO}_{2}$

Mass: $264.2 \mathrm{~g} \cdot \mathrm{mol}^{-1}$

IR (neat): 1687, 1476, 1467, 1449, 1417, 1393, 1365, 1335, 1315, 1274, 1239, 1159, 1106, 1053, 1012, $997,933 \mathrm{~cm}^{-1}$

${ }^{1} \mathrm{H}$ NMR $\left(400 \mathrm{MHz}, \mathrm{CDCl}_{3}\right) \delta 4.34$ (hept $\left._{\mathrm{app}}, J=3.7 \mathrm{~Hz}, 1 \mathrm{H}\right), 3.68$ (br ddd, $\left.J=13.2,6.8,3.7 \mathrm{~Hz}, 2 \mathrm{H}\right)$, 3.31 (br ddd, $J=13.6,7.7,3.6 \mathrm{~Hz}, 2 \mathrm{H}), 2.14-2.01(\mathrm{~m}, 2 \mathrm{H}), 1.98-1.86(\mathrm{~m}, 2 \mathrm{H}), 1.45(\mathrm{~s}, 9 \mathrm{H})$

${ }^{13} \mathrm{C}$ NMR $\left(100 \mathrm{MHz}, \mathrm{CDCl}_{3}\right) \delta 154.7,79.9,49.6,42.2(2 \mathrm{C}), 35.7$ (2C), 28.5 (3C)

MS (EI) m/z: 264 (1), 210 (9), 209 (7), 208 (12), 207 (7), 192 (7), 190 (7), 128 (15), 84 (44), 57 (100), $56(10), 55(8)$

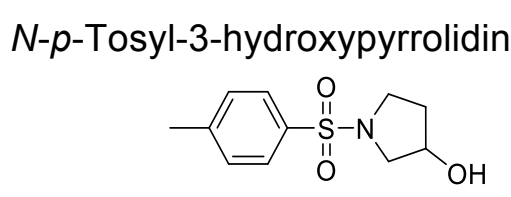

Tosylamide S11 was prepared according to Procedure C from 3-hydroxypyrrolidine (S12) (500 mg, $5.62 \mathrm{mmol}, 1$ equiv), $\mathrm{Et}_{3} \mathrm{~N}$ ( $0.82 \mathrm{~mL}, 5.91 \mathrm{mmol}, 1.05$ equiv) and $\mathrm{TsCl}$ ( $1.13 \mathrm{~g}, 5.91 \mathrm{mmol}, 1.05$ equiv). Purification by flash chromatography on silica gel (gradient of elution $\mathrm{PE} / \mathrm{Et}_{2} \mathrm{O}=40: 60$ to $\mathrm{Et}_{2} \mathrm{O} 100 \%$ ) yielded tosylamide S11 (541 mg, $2.24 \mathrm{mmol}, 40 \%$ ) as a white solid.

Formula: $\mathrm{C}_{11} \mathrm{H}_{15} \mathrm{NO}_{3} \mathrm{~S}$

Mass: $241.3 \mathrm{~g} \cdot \mathrm{mol}^{-1}$

mp: $107-110{ }^{\circ} \mathrm{C}$

IR (neat): 1597, 1494, 1441, 1328, 1208, 1154, 1093, 1030, 1015, 986, $916 \mathrm{~cm}^{-1}$

${ }^{1} \mathrm{H}$ NMR $\left(400 \mathrm{MHz}, \mathrm{CDCl}_{3}\right) \delta 7.72(\mathrm{~d}, J=8.3 \mathrm{~Hz}, 2 \mathrm{H}), 7.32(\mathrm{~d}, J=7.9 \mathrm{~Hz}, 2 \mathrm{H}), 4.38\left(\mathrm{br} \mathrm{s}_{\mathrm{app}}, 1 \mathrm{H}\right)$, $3.47-3.29(\mathrm{~m}, 3 \mathrm{H}), 3.23(\mathrm{ddd}, J=11.1,2.0,1.5 \mathrm{~Hz}, 1 \mathrm{H}), 2.43(\mathrm{~s}, 3 \mathrm{H}), 1.95(\mathrm{~m}, 1 \mathrm{H}), 1.81(\mathrm{~m}, 1 \mathrm{H}), 1.52$ $(\mathrm{s}, 1 \mathrm{H})$

${ }^{13} \mathrm{C}$ NMR $\left(100 \mathrm{MHz}, \mathrm{CDCl}_{3}\right) \delta 143.6,133.7,129.8(2 \mathrm{C}), 127.7(2 \mathrm{C}), 70.9,56.2,46.0,34.3,21.6$

MS (EI) m/z: 241 (7), 155 (7), 105 (6), 92 (12), 91 (43), 89 (5), 87 (5), 86 (100), 65 (25), 63 (5), 57 (7).

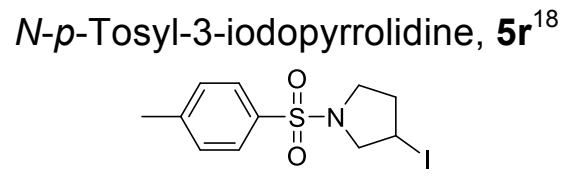

lodide $5 \mathbf{r}$ was prepared according to Procedure B from N-Tosyl-3-hydroxypyrrolidine (S11) (250 mg). Purification by flash chromatography on silica gel (gradient of elution $\mathrm{PE} / \mathrm{Et}_{2} \mathrm{O}=70: 30$ to $\mathrm{Et}_{2} \mathrm{O} 100 \%$ ) yielded iodide $5 \mathbf{r}(230 \mathrm{mg}, 0.65 \mathrm{mmol}, 63 \%)$ as a white solid.

Formula: $\mathrm{C}_{11} \mathrm{H}_{14} \mathrm{INO}_{2} \mathrm{~S}$

Mass: $351.2 \mathrm{~g} \cdot \mathrm{mol}^{-1}$

mp: $107-109^{\circ} \mathrm{C}$

\footnotetext{
${ }^{17}$ Hodgson, D. M.; Fleming, M. J.; Xu, Z.; Lin, C.; Stanway, S. J. Chem. Commun. 2006, No. 30, 3226-3228.

${ }^{18}$ Lu, X.-Y.; Liu, J.-H.; Lu, X.; Zhang, Z.-Q.; Gong, T.-J.; Xiao, B.; Fu, Y. Chem. Commun. 2016, 52, 5324-5327.
} 
IR (neat): $1597,1493,1439,1399,1343,1305,1291,1260,1228,1186,1155,1095,1046,1013$, $916 \mathrm{~cm}^{-1}$

${ }^{1} \mathrm{H}$ NMR $\left(400 \mathrm{MHz}, \mathrm{CDCl}_{3}\right) \delta 7.73(\mathrm{~d}, J=7.8 \mathrm{~Hz}, 2 \mathrm{H}), 7.34(\mathrm{~d}, J=7.8 \mathrm{~Hz}, 2 \mathrm{H}), 4.16$ (quint $_{\text {app }}$, $J=5.4 \mathrm{~Hz}, 1 \mathrm{H}), 3.90(\mathrm{br} d d d, J=11.6,5.8,1.6 \mathrm{~Hz}, 1 \mathrm{H}), 3.56(\mathrm{dd}, J=11.7,4.7 \mathrm{~Hz}, 1 \mathrm{H}), 3.43\left(\mathrm{br} \mathrm{t}_{\mathrm{app}}, J\right.$ $=6.7 \mathrm{~Hz}, 2 \mathrm{H}), 2.43(\mathrm{~s}, 3 \mathrm{H}), 2.26(\mathrm{~m}, 1 \mathrm{H}), 2.12(\mathrm{~m}, 1 \mathrm{H})$

${ }^{13} \mathrm{C}$ NMR $\left(100 \mathrm{MHz}, \mathrm{CDCl}_{3}\right) \delta 143.9,133.9,129.9(2 \mathrm{C}), 127.7(2 \mathrm{C}), 58.7,47.0,38.2,21.7,17.4$

MS (EI) m/z: 351 (12), 225 (6), 224 (40), 223 (6), 155 (44), 92 (11), 91 (100), 89 (6), 69 (9), 68 (23), 65 (23)

N-Boc-4-(o-tolylsulfonyloxy)piperidine, 5s<smiles>Cc1ccccc1S(=O)(=O)OC1CCN(C(=O)OC(C)(C)C)CC1</smiles>

Compound 5s was prepared according to Procedure C from N-Boc-4-hydroxypiperidine (10) (213 mg, $1.06 \mathrm{mmol}, 1$ equiv), $\mathrm{Et}_{3} \mathrm{~N}(0.290 \mathrm{~mL}, 2.12 \mathrm{mmol}, 2$ equiv) and o-methylbenzene-1-sulfonyl chloride ( $0.240 \mathrm{~mL}, 1.59 \mathrm{mmol}, 1.5$ equiv). Purification by flash chromatography on silica gel (PE/EA $=60: 40)$ yielded $5 \mathrm{~s}$ (166 $\mathrm{mg}, 0.470 \mathrm{mmol}, 44 \%$ ) as a white solid.

Formula: $\mathrm{C}_{17} \mathrm{H}_{25} \mathrm{NO}_{5} \mathrm{~S}$

Mass: $355.5 \mathrm{~g} \cdot \mathrm{mol}^{-1}$

mp: $82-84{ }^{\circ} \mathrm{C}$

IR (neat): 1688, 1474, 1455, 1421, 1364, 1354, 1276, 1237, 1178, 1136, 1067, 1010, 941, $905 \mathrm{~cm}^{-1}$

${ }^{1} \mathrm{H}$ NMR $\left(400 \mathrm{MHz}, \mathrm{CDCl}_{3}\right) \delta 7.98(\mathrm{~d}, J=7.2 \mathrm{~Hz}, 1 \mathrm{H}), 7.51\left(\mathrm{t}_{\mathrm{app}}, J=7.5 \mathrm{~Hz}, 1 \mathrm{H}\right), 7.39-7.30(\mathrm{~m}, 2 \mathrm{H})$, $4.66(\mathrm{~m}, 1 \mathrm{H}), 3.66-3.48(\mathrm{~m}, 2 \mathrm{H}), 3.30-3.16(\mathrm{~m}, 2 \mathrm{H}), 2.65(\mathrm{~s}, 3 \mathrm{H}), 1.89-1.61(\mathrm{~m}, 4 \mathrm{H}), 1.42(\mathrm{~s}, 9 \mathrm{H})$

${ }^{13} \mathrm{C}$ NMR $\left(100 \mathrm{MHz}, \mathrm{CDCl}_{3}\right) \delta 154.6,138.2,135.7,133.8,132.6,129.5,126.3,80.0,78.2,40.4$ (2C), $31.3(2 \mathrm{C}), 28.4(3 \mathrm{C}), 20.3$

MS (EI) m/z: 355 (1), 128 (14), 127 (49), 126 (23), 91 (17), 84 (26), 83 (40), 82 (21), 68 (9), 65 (6), 57 (100), 56 (10), 55 (11).

HRMS (ESI) m/z: $[\mathrm{M}+\mathrm{Na}]^{+}$Calcd for $\mathrm{C}_{17} \mathrm{H}_{25} \mathrm{NO}_{5} \mathrm{SNa} 378.1346$, Found 378.1348.

\section{I.3.2. Synthesis of acyclic secondary iodides}

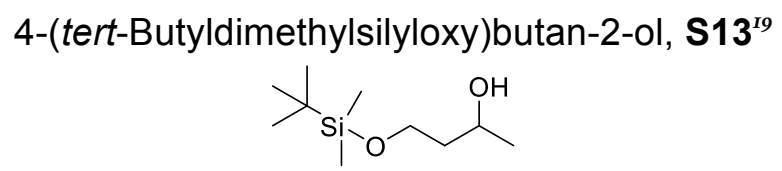

To a solution of 1,3-butanediol (S14) $(1.50 \mathrm{~mL}, 16.5 \mathrm{mmol}, 1$ equiv) and imidazole $(2.72 \mathrm{~g}, 39.6 \mathrm{mmol}$, 2.4 equiv) in $\mathrm{CH}_{2} \mathrm{Cl}_{2}(40 \mathrm{~mL})$ at $0{ }^{\circ} \mathrm{C}$ was cannulated a solution of TBSCl $(3.53 \mathrm{~mL}, 19.8 \mathrm{mmol}, 1.2$ equiv) in $\mathrm{CH}_{2} \mathrm{Cl}_{2}(15 \mathrm{~mL})$. The reaction mixture was allowed to warm up to rt and stirred overnight. Brine was added, and the aqueous phase was extracted with $\mathrm{Et}_{2} \mathrm{O}$. The combined organic phases were dried over $\mathrm{MgSO}_{4}$, filtered and concentrated under reduced pressure. Purification by flash chromatography on silica gel (gradient of elution $\mathrm{PE} / \mathrm{Et}_{2} \mathrm{O}=80: 20$ to $70: 30$ ) yielded alcohol S13 (2.90 g, $14.2 \mathrm{mmol}, 86 \%$ ) as a colourless liquid.

Formula: $\mathrm{C}_{10} \mathrm{H}_{24} \mathrm{O}_{2} \mathrm{Si}$

Mass: $204.4 \mathrm{~g} \cdot \mathrm{mol}^{-1}$

IR (neat): $3355,1472,1463,1410,1388,1362,1254,1085,997,938,910 \mathrm{~cm}^{-1}$

${ }^{1} \mathrm{H}$ NMR $\left(400 \mathrm{MHz}, \mathrm{CDCl}_{3}\right) \delta 4.01(\mathrm{~m}, 1 \mathrm{H}), 3.88(\mathrm{~m}, 1 \mathrm{H}), 3.80(\mathrm{~m}, 1 \mathrm{H}), 3.40(\mathrm{br} \mathrm{s}, 1 \mathrm{H}), 1.74-1.56(\mathrm{~m}$, $2 \mathrm{H}), 1.22-1.14(\mathrm{~m}, 3 \mathrm{H}), 0.89(\mathrm{br} \mathrm{s}, 9 \mathrm{H}), 0.07(\mathrm{~s}, 3 \mathrm{H}), 0.06(\mathrm{~s}, 3 \mathrm{H})$

\footnotetext{
${ }^{19}$ Dupuy, S.; Zhang, K.-F.; Goutierre, A.-S.; Baudoin, O. Angew. Chem. Int. Ed. 2016, 55, 14793-14797.
} 
${ }^{13} \mathrm{C}$ NMR $\left(100 \mathrm{MHz}, \mathrm{CDCl}_{3}\right) \delta 68.3,62.8,40.0,25.9(3 \mathrm{C}), 23.4,18.2,-5.47,-5.52$

MS (EI) m/z: 147 (7), 106 (7), 105 (83), 89 (6), 77 (6), 76 (7), 75 (100), 73 (12), 59 (6), 55 (13)

2-lodo-4-(tert-butyldimethylsilyloxy)butane, $50^{20}$<smiles>CC(I)CCO[Si](C)(C)C(C)(C)C</smiles>

lodide 5o was prepared according to Procedure A from 4-(tert-butyldimethylsilyloxy)butan-2-ol (S13) $(2.50 \mathrm{~g}, 12.47 \mathrm{mmol})$. Purification by flash chromatography on silica gel $\left(\mathrm{PE} / \mathrm{Et}_{2} \mathrm{O}=95: 5\right)$ yielded iodide $50(3.10 \mathrm{~g}, 9.70 \mathrm{mmol}, 78 \%)$ as a pale yellow liquid.

Formula: $\mathrm{C}_{10} \mathrm{H}_{23} \mathrm{OSil}$

Mass: $314.3 \mathrm{~g} \cdot \mathrm{mol}^{-1}$

IR (neat): 1724, 1591, 1501, 1470, 1446, 1398, 1361, 1266, 1174, 1113, 1099, 1071, 1034, 1012, 987, $968,948 \mathrm{~cm}^{-1}$

${ }^{1} \mathrm{H}$ NMR $\left(400 \mathrm{MHz}, \mathrm{CDCl}_{3}\right) \delta 4.35(\mathrm{~m}, 1 \mathrm{H}), 3.76$ (ddd, $\left.J=10.3,8.1,4.8 \mathrm{~Hz}, 1 \mathrm{H}\right), 3.65$ (ddd, $J=10.3$, $8.1,4.8 \mathrm{~Hz}, 1 \mathrm{H}), 2.01(\mathrm{~m}, 1 \mathrm{H}), 1.96(\mathrm{~d}, J=6.9 \mathrm{~Hz}, 3 \mathrm{H}), 1.79(\mathrm{~m}, 1 \mathrm{H}), 0.89(\mathrm{~s}, 9 \mathrm{H}), 0.08(\mathrm{~s}, 3 \mathrm{H}), 0.07(\mathrm{~s}$, $3 \mathrm{H})$

${ }^{13} \mathrm{C}$ NMR $\left(100 \mathrm{MHz}, \mathrm{CDCl}_{3}\right) \delta 62.8,45.5,29.2,26.2,26.0(3 \mathrm{C}), 18.4,-5.19,-5.21$

MS (EI) m/z: 258 (10), 257 (89), 216 (8), 215 (100), 185 (60), 129 (30), 115 (9), 101 (14), 89 (18), 75 (50), 73 (41), 61 (6), 59 (19), 58 (11), 57 (12), 55 (47)

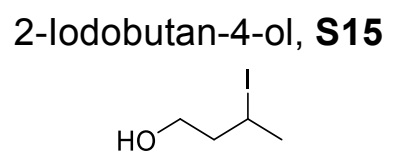

To a solution of 2-iodo-4-(tert-butyldimethylsilyloxy)butane (5o) (1.50 g, $4.77 \mathrm{mmol}, 1$ equiv) in $\mathrm{MeOH}$ $(48 \mathrm{~mL})$ was added $p \mathrm{TsOH}_{\bullet} \mathrm{H}_{2} \mathrm{O}(182 \mathrm{mg}, 0.950 \mathrm{mmol}, 0.2$ equiv). The reaction mixture was stirred at rt overnight. A saturated aqueous solution of $\mathrm{NaHCO}_{3}$ was added and the aqueous phase was extracted with $\mathrm{Et}_{2} \mathrm{O}$. The combined organic phases were dried over $\mathrm{MgSO}_{4}$, filtered and concentrated under reduced pressure. Purification by flash chromatography on silica gel $\left(\mathrm{PE} / \mathrm{Et}_{2} \mathrm{O}=80: 20\right)$ yielded iodo-alcohol S15 (737 mg, $3.68 \mathrm{mmol}, 77 \%)$ as a colourless liquid.

Formula: $\mathrm{C}_{4} \mathrm{H}_{9} \mathrm{IO}$

Mass: $200.0 \mathrm{~g} \cdot \mathrm{mol}^{-1}$

IR (neat): 3305, 1463, 1444, 1416, 1378, 1253, 1219, 1151, 1123, 1091, 1050, $1024 \mathrm{~cm}^{-1}$

${ }^{1} \mathrm{H}$ NMR $\left(400 \mathrm{MHz}, \mathrm{CDCl}_{3}\right) \delta 4.35(\mathrm{~m}, 1 \mathrm{H}), 3.83$ (ddd, $\left.J=10.7,5.8,4.8 \mathrm{~Hz}, 1 \mathrm{H}\right), 3.74$ (ddd, $J=10.8$, 8.1, $5.1 \mathrm{~Hz}, 1 \mathrm{H}$ ), 2.04 (ddd, $J=19.7,9.8,5.0 \mathrm{~Hz}, 1 \mathrm{H}), 1.98(\mathrm{~d}, J=6.9 \mathrm{~Hz}, 3 \mathrm{H}), 1.85(\mathrm{~m}, 1 \mathrm{H}), 1.60$ (brs, $1 \mathrm{H})$

${ }^{13} \mathrm{C}$ NMR $\left(100 \mathrm{MHz}, \mathrm{CDCl}_{3}\right) \delta 62.7,44.9,29.2,26.1$

MS (EI) m/z: 200 (4), 127 (2), 74 (3), 73 (52), 57 (3), 56 (5), 55 (100), 53 (2)

HRMS (ESI) m/z: $[\mathrm{M}+\mathrm{H}]^{+}$Calcd for $\mathrm{C}_{4} \mathrm{H}_{9} \mathrm{IOH} 200.9771$, Found 200.9770

$N$-Boc, $N$-tosyl-3-lodobutylamine $5 p$

\footnotetext{
${ }^{20}$ Hofmayer, M. S.; Hammann, J. M.; Cahiez, G.; Knochel, P. Synlett 2018, 29, 65-70.
} 


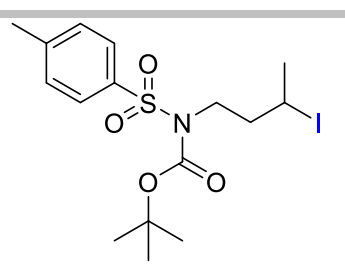

3-lodobutan-1-ol (S15) (730 mg, $3.65 \mathrm{mmol}, 1$ equiv), $\mathrm{PPh}_{3}$ (957 mg, $3.65 \mathrm{mmol}, 1$ equiv) and $\mathrm{NH}$ (Boc)Ts (990 mg, $3.65 \mathrm{mmol}, 1$ equiv) were dissolved in THF (22 mL). DIAD was added by a syringe pump over $10 \mathrm{~min}\left(4.32 \mathrm{~mL} / \mathrm{h}, 0.720 \mathrm{~mL}, 3.65 \mathrm{mmol}, 1\right.$ equiv) at $0{ }^{\circ} \mathrm{C}$. The reaction mixture was allowed to warm to $\mathrm{rt}$ and stirred overnight. The reaction mixture was concentrated under reduced pressure and purification by flash chromatography on silica gel $\left(\mathrm{PE} / \mathrm{Et}_{2} \mathrm{O}=90: 10\right)$ yielded iodide $\mathbf{5 p}$ (1.30 g, $2.89 \mathrm{mmol}, 79 \%)$ as a colourless oil.

Formula: $\mathrm{C}_{16} \mathrm{H}_{24} \mathrm{INO}_{4} \mathrm{~S}$

Mass: $453.3 \mathrm{~g} \cdot \mathrm{mol}^{-1}$

IR (neat): 1725, 1597, 1495, 1475, 1445, 1394, 1352, 1288, 1257, 1234, 1186, 1154, 1140, 1088, 1050, 1020, 991, 947, $909 \mathrm{~cm}^{-1}$

${ }^{1} \mathrm{H}$ NMR $\left(400 \mathrm{MHz}, \mathrm{CDCl}_{3}\right) \delta 7.77(\mathrm{~d}, J=8.3 \mathrm{~Hz}, 2 \mathrm{H}), 7.31(\mathrm{~d}, J=8.1 \mathrm{~Hz}, 2 \mathrm{H}), 4.15(\mathrm{dqd}, J=8.8,6.8$, $4.8 \mathrm{~Hz}, 1 \mathrm{H}$ ), 3.99 (ddd, $J=14.3,10.0,1.3 \mathrm{~Hz}, 1 \mathrm{H}$ ), 3.83 (ddd, $J=14.3,10.0,1.3 \mathrm{~Hz}, 1 \mathrm{H}), 2.44(\mathrm{~s}, 3 \mathrm{H}$ ), $2.27(\mathrm{~m}, 1 \mathrm{H}), 2.10(\mathrm{~m}, 1 \mathrm{H}), 1.98(\mathrm{~d}, J=6.9 \mathrm{~Hz}, 3 \mathrm{H}), 1.35(\mathrm{~s}, 9 \mathrm{H})$

${ }^{13} \mathrm{C}$ NMR $\left(100 \mathrm{MHz}, \mathrm{CDCl}_{3}\right) \delta 150.9,144.3,137.2,129.4$ (2C), 127.9 (2C), 84.6, 47.7, 42.5, 29.0, 28.0 (3C), 24.3, 21.68

HRMS (ESI) m/z: [M+H] $]^{+}$Calcd for $\mathrm{C}_{16} \mathrm{H}_{24} \mathrm{INO}_{4} \mathrm{SH} 454.0543$, Found 454.0543

\section{I.4. Synthesis of the Grignard reagents and optimization of the synthesis of the} aryl-BCP-Grignard reagents

- $p$-Methoxyphenylmagnesium bromine solution in $\mathrm{Et}_{2} \mathrm{O}$

Mg turnings (292 mg, $12.00 \mathrm{mmol}, 1.2$ equiv) were covered with $\mathrm{Et}_{2} \mathrm{O}(1 \mathrm{~mL})$ and a crystal of $\mathrm{I}_{2}$ was added. The reaction mixture was warmed to $40{ }^{\circ} \mathrm{C}$ (water bath) and part of the $p$-bromoanisole was added without any stirring. When the $\mathrm{I}_{2}$ colour disappeared, the rest of $p$-bromoanisole in solution in $\mathrm{Et}_{2} \mathrm{O}$ was added dropwise over $10 \mathrm{~min}$ with stirring $\left(1.3 \mathrm{~mL}, 10.00 \mathrm{mmoL}, 1\right.$ equiv in $\left.10 \mathrm{~mL} \mathrm{Et}_{2} \mathrm{O}\right)$ and the reaction mixture was stirred at rt overnight. The Grignard reagent formed was titrated and the concentration was measured to be around $0.47 \mathrm{M}{ }^{1}$

- [1.1.1]Propellane synthesis

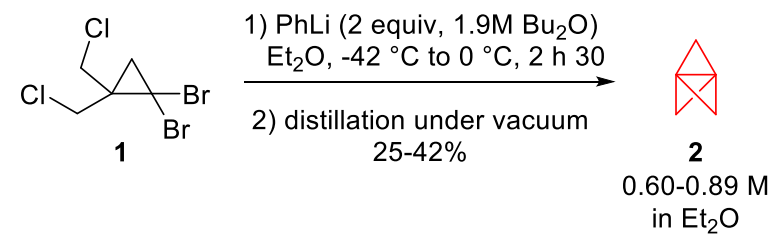

To a solution of 1,1-dibromo-2,2-bis(chloromethyl)cyclopropane 1 (6.0 g, 18.19 mmol, 1 equiv) in $\mathrm{Et}_{2} \mathrm{O}$ $(11.2 \mathrm{~mL})$ at $-40{ }^{\circ} \mathrm{C}$, was added dropwise a solution of $\mathrm{PhLi}$ in $\mathrm{Bu}_{2} \mathrm{O}\left(1.9 \mathrm{M}\right.$ solution in $\mathrm{Bu}_{2} \mathrm{O}, 19.15 \mathrm{~mL}$, $36.39 \mathrm{mmol}, 2$ equiv). The reaction was allowed to warm to $0{ }^{\circ} \mathrm{C}$ and stirred. After $2.5 \mathrm{~h}$, the reaction mixture was persistently a suspension of beige colour. The septum was replaced by a distillation set, the reaction mixture was kept at rt and the collecting flask was cooled to $-78{ }^{\circ} \mathrm{C}$ (dry ice and acetone). The distillation was achieved under a pressure superior to 50 mbar (exceeding $50 \mathrm{mbar}$ a lot of phenylbromine and $\mathrm{Bu}_{2} \mathrm{O}$ were contaminating the product). After completion, the flask of the resulting solution of [1.1.1]propellane 2 in $\mathrm{Et}_{2} \mathrm{O}$ was transferred under argon to an ice bath and the solution was 
titrated by ${ }^{1} \mathrm{H}$ NMR according to Baran et. al. method (100 $\mu \mathrm{L}$ of solution $+25 \mu \mathrm{L}$ of dichloroethane as internal standard dissolved in chloroform). ${ }^{21}$ The concentration of 2 varied between 0.60 and $0.89 \mathrm{M}$.

- Bicyclo[1.1.1]pentane Grignard reagents substituted by an alkyl group at the C3 position: Alk $=t$-Bu

3a, iPr 3b, cyclopentyl 3c

A freshly distilled solution of [1.1.1]propellane 2 was transferred to a vial (reaction tube) and 1 equiv of the corresponding alkyl Grignard reagent $\left(\mathrm{Et}_{2} \mathrm{O}\right.$ solution) was added rapidly at $\mathrm{rt}$. The vial was sealed, and the reaction mixture was stirred at $\mathrm{rt}$ for $48 \mathrm{~h}$. The formation of $3 \mathrm{a}-3 \mathrm{c}$ can easily be monitored by ${ }^{1} \mathrm{H}$ NMR analysis in MeOD, which shows their quantitative formation.

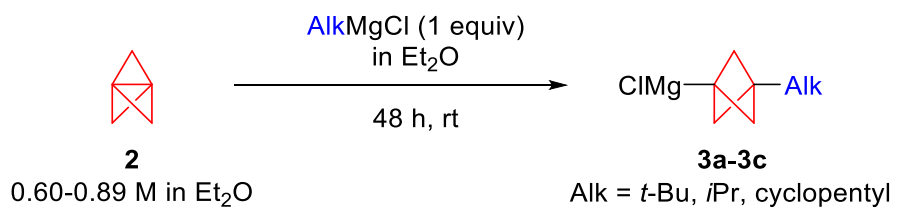

- Bicyclo[1.1.1]pentane Grignard reagents substituted by an aromatic group at the C3 position: $p$-fluorophenyl 3d, p-methoxyphenyl 3e, $p$-tolyl $\mathbf{3 f}$

A freshly distilled solution of [1.1.1]propellane 2 was transferred to a vial and the corresponding aryl Grignard reagent ( $\mathrm{Et}_{2} \mathrm{O}$ solution) was added rapidly at rt. The vial was sealed, and the reaction mixture was stirred for 3 days at $40{ }^{\circ} \mathrm{C}$. The formation of $\mathbf{3 d - 3 f}$ can easily be monitored by ${ }^{1} \mathrm{H}$ NMR analysis in MeOD. The exact composition of the mixture can be determined.

Commercially available $p$-fluorophenylmagnesium bromide (1.86 $\mathrm{M}_{\text {in }} \mathrm{Et}_{2} \mathrm{O}, 1.0$ equiv) was employed and yielded a mixture composed of the desired bicyclopentane Grignard reagent $\mathbf{3} \mathbf{d}$ and $p$ fluorophenylmagnesium bromide $4 \mathbf{a}(\mathbf{3} \mathbf{d} / \mathbf{4 a}=1: 0.6)$.

Freshly prepared $p$-methoxyphenylmagnesium bromide $\left(0.47 \mathrm{M}_{\text {in }} \mathrm{Et}_{2} \mathrm{O}, 0.5\right.$ equiv) was added and led to a mixture composed of the desired bicyclopentane Grignard reagent $3 e$ and p-methoxyphenylmagnesium bromide $\mathbf{4 b}(\mathbf{3 e} / \mathbf{4} \mathbf{b}=1: 0.6)$.

Freshly prepared $p$-tolylmagnesium bromide $\left(0.40 \mathrm{M}\right.$ in $\mathrm{Et}_{2} \mathrm{O}, 1.0$ equiv) was added and produced a mixture composed of the desired bicyclopentane Grignard reagent $\mathbf{3 f}$ and p-methoxyphenylmagnesium bromide $\mathbf{4 c}(\mathbf{3} \mathbf{f} / \mathbf{4} \mathbf{c}=1: 0.6)$.

${ }^{21}$ Gianatassio, R.; Lopchuk, J. M.; Wang, J.; Pan, C.-M.; Malins, L. R.; Prieto, L.; Brandt, T. A.; Collins, M. R.; Gallego, G. M.; Sach, N. W.; Spangler, J. E.; Zhu, H.; Zhu, J.; Baran, P. S. Science 2016, 351, 241-246. 


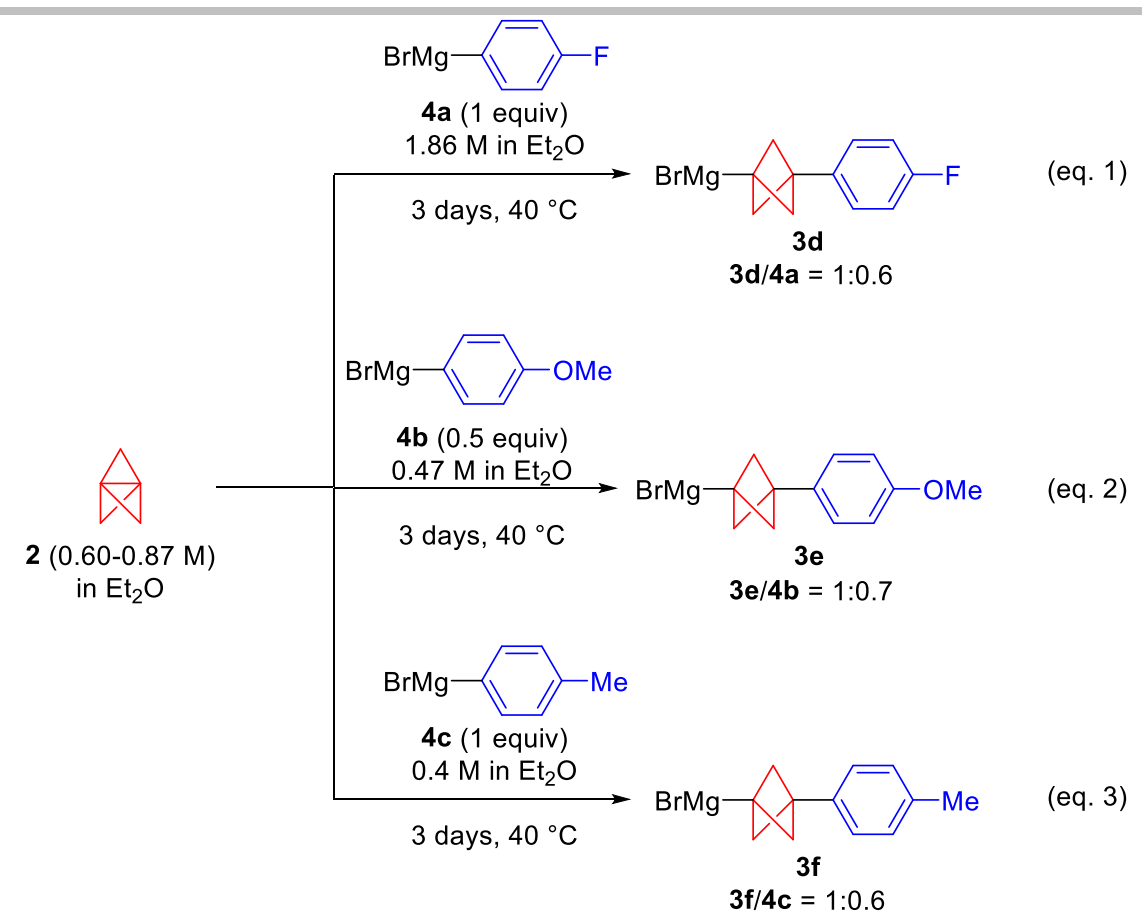

The above results were the best results obtained, however some investigations to improve these results were carried out and are detailed hereafter. We chose not to increase the temperature above $40{ }^{\circ} \mathrm{C}$ when $\mathrm{Et}_{2} \mathrm{O}$ was used for security reasons eventhough if, in the literature, several groups are using temperatures above $60^{\circ} \mathrm{C}$ even up to $100{ }^{\circ} \mathrm{C}$.

Increasing the reaction time at $40{ }^{\circ} \mathrm{C}$ for the reaction between 2 and $4 \mathrm{a}$ in $\mathrm{Et}_{2} \mathrm{O}$ did not have any impact (ratio $\mathbf{3} \mathbf{d}_{\mathrm{D}} / \mathbf{4} \mathbf{a}_{\mathrm{D}}=1: 0.6$ ) (Table 1, entries 1-2). Decreasing the temperature from $40{ }^{\circ} \mathrm{C}$ to $\mathrm{rt}$, decreases the conversion of 2 when reacted with 4 a (Table 1, entry 3 ).

\section{Table 1}

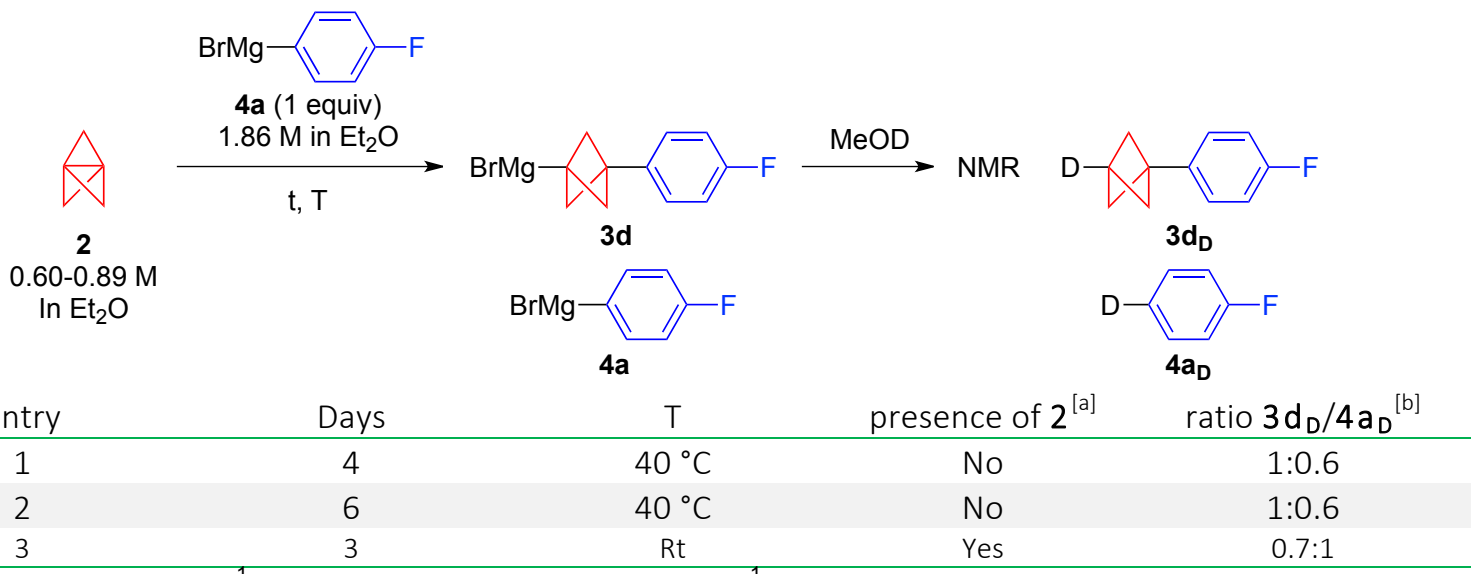

[a] Detected on the crude ${ }^{1} \mathrm{H}$ NMR. [b] Calculated on the crude ${ }^{1} \mathrm{H}$ NMR.

Compared to $\mathrm{Et}_{2} \mathrm{O}$, THF was detrimental to the formation of BCP Grignard reagents. When 2 was treated with $\mathbf{4 b}$ in THF, the desired BCP Grignard reagent $3 \mathbf{e}$ was not formed, probably due to the better chelating properties of THF in comparison to $\mathrm{Et}_{2} \mathrm{O}$. The addition of $\mathrm{LiCl}$ had no impact on the reaction outcome (Table 2)

Table 2 


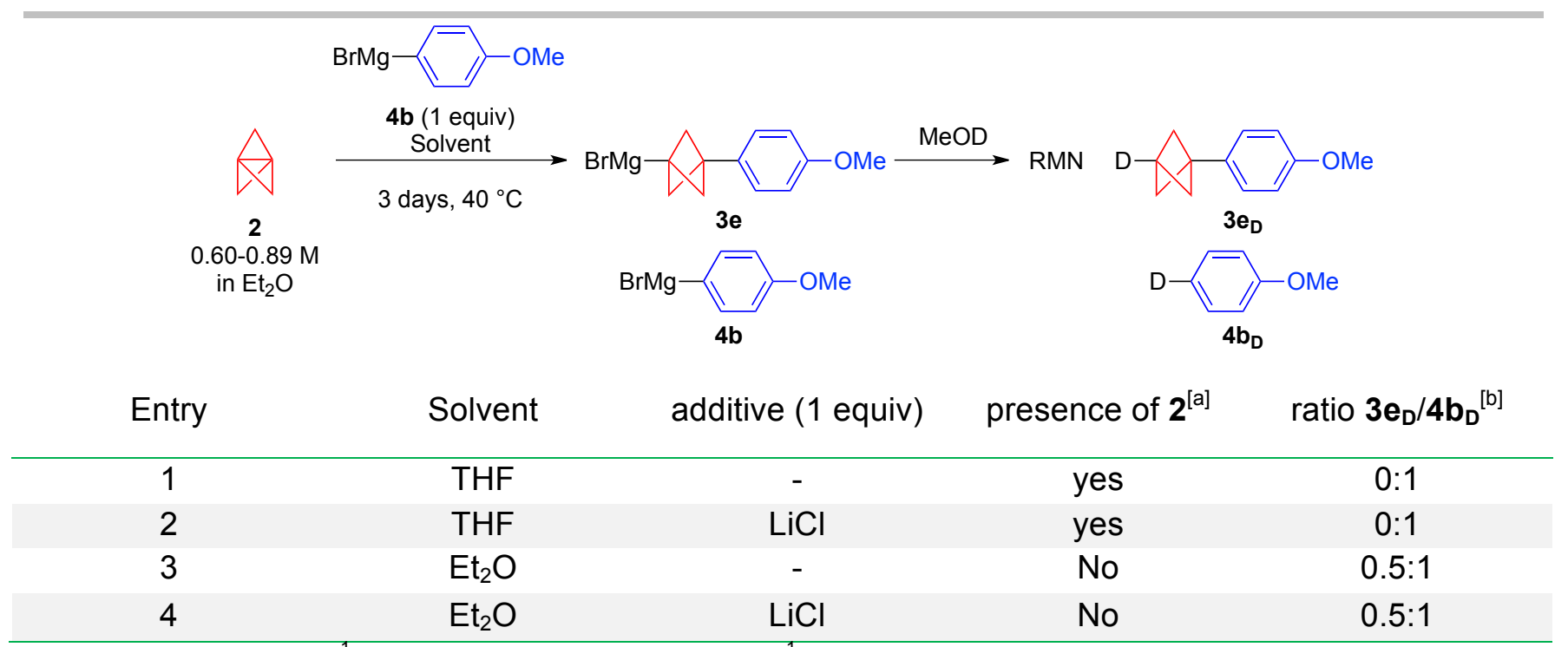

[a] Detected on the crude ${ }^{1} \mathrm{H}$ NMR. [b] Calculated on the crude ${ }^{1} \mathrm{H}$ NMR.

Treatment of $\mathbf{2}$ with $\mathbf{4 b}$ in the presence of 1 equiv of TMEDA did not have any impact on the outcome of the reaction (ratio $\mathbf{3} \mathbf{e}_{\mathrm{D}} / \mathbf{4} \mathbf{b}_{\mathrm{D}}=\mathbf{0 . 5 : 1}$ ) (Table 3 , entries 1 and 2). To reach better yields in $\mathbf{3 e}$, an excess of [1.1.1]propellane 2 was necessary (Table 3 , entry 3 ).

Table 3

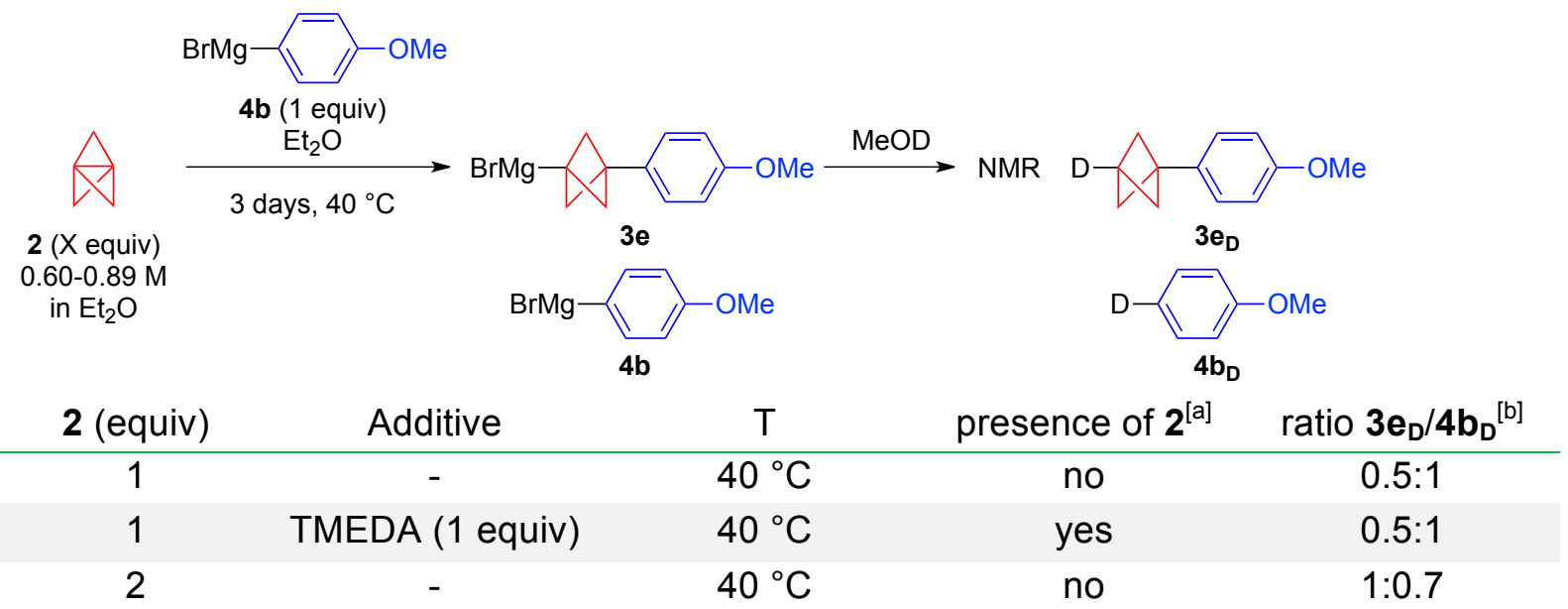

[a] Detected on the crude ${ }^{1} \mathrm{H}$ NMR. [b] Calculated on the crude ${ }^{1} \mathrm{H}$ NMR.

\section{II- Copper-catalyzed cross-coupling}

\section{Procedure E:}

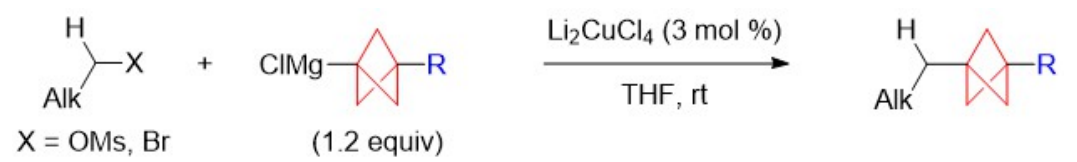

To a solution of primary mesylate or primary bromide in THF was added $\mathrm{Li}_{2} \mathrm{CuCl}_{4}(1 \mathrm{M}$ solution in THF, $3 \mathrm{~mol} \%$ ) followed by the Grignard reagent (in solution in $\mathrm{Et}_{2} \mathrm{O}$, rapid manual dropwise addition of 1.2 equiv) at $\mathrm{rt}^{22}$ The reaction was allowed to stir at rt until completion ( $\mathrm{t}=30 \mathrm{~min}$ for $\mathrm{R}=$ alkyl and $2 \mathrm{~h}$ for

\footnotetext{
${ }^{22}$ When $\mathbf{3 d}$, 3e or $\mathbf{3 f}$ were used, the exact composition of the solutions were calculated using ${ }^{1} \mathrm{H}$ NMR spectra recorded in MeOD. The appropriate amount of solution was added in order to introduce 1.2 equiv of the corresponding BCP Grignard reagent.
} 
$\mathrm{R}=$ aryl). ${ }^{23}$ The reaction was quenched with a saturated aqueous solution of $\mathrm{NH}_{4} \mathrm{Cl}$ and the aqueous phase was extracted with diethyl ether (twice). The combined organic phases were dried over $\mathrm{MgSO}_{4}$, filtered and concentrated under reduced pressure. Purification by flash chromatography on silica gel afforded the desired coupling product.

\section{Procedure F:}

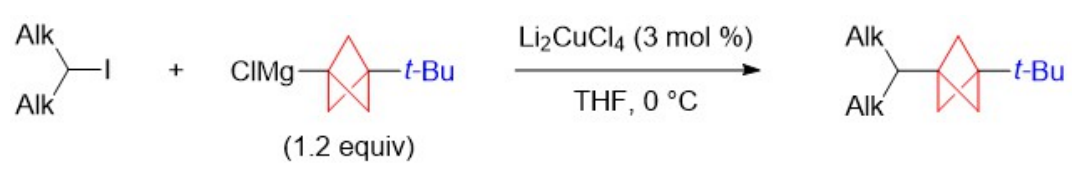

To a solution of secondary iodide in THF was added $\mathrm{Li}_{2} \mathrm{CuCl}_{4}(1 \mathrm{M}$ solution in THF, $3 \mathrm{~mol} \%)$ followed by the Grignard reagent (in solution in $\mathrm{Et}_{2} \mathrm{O}$, rapid manual dropwise addition of 1.2 equiv) at $0{ }^{\circ} \mathrm{C}$. The reaction was allowed to stir at $0{ }^{\circ} \mathrm{C}$ until completion. The reaction was quenched with a saturated aqueous solution of $\mathrm{NH}_{4} \mathrm{Cl}$ and the aqueous phase was extracted with diethyl ether (twice). The combined organic phases were dried over $\mathrm{MgSO}_{4}$, filtered and concentrated under reduced pressure. Purification by flash chromatography on silica gel afforded the desired coupling product.

\section{Procedure G:}

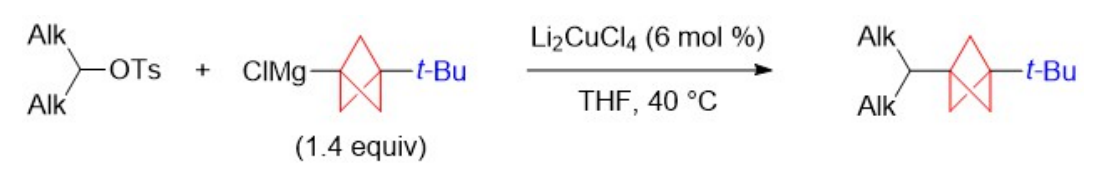

To a solution of secondary tosylate in THF was added $\mathrm{Li}_{2} \mathrm{CuCl}_{4}(1 \mathrm{M}$ solution in THF, $6 \mathrm{~mol} \%)$ followed by the addition of the Grignard reagent (in solution in $\mathrm{Et}_{2} \mathrm{O}$, rapid manual dropwise addition of 1.4 equiv) at $0{ }^{\circ} \mathrm{C}$. The reaction was allowed to stir at $0{ }^{\circ} \mathrm{C}$ until completion. The reaction was quenched with a saturated aqueous solution of $\mathrm{NH}_{4} \mathrm{Cl}$ and the aqueous phase was extracted with diethyl ether. The combined organic phases were dried over $\mathrm{MgSO}_{4}$, filtered and concentrated under reduced pressure. Purification by flash chromatography on silica gel afforded the desired coupling product.

\section{II.1. Cross-coupling between primary alkyl (pseudo)halides and BCP Grignard reagents}

\section{II.1.1. Optimization of the cross-coupling between primary alkyl (pseudo)halides and BCP} Grignard reagents

- In the absence of any catalyst

When iodide $\mathbf{5 a}$ was reacted with Grignard reagent $\mathbf{3 a}$ in the absence of any catalyst, after $24 \mathrm{~h}, \mathbf{6 a}$ was formed but only in small quantity $(5 \mathbf{a} / \mathbf{6} \mathbf{a}=1: 0.3)$, showing the essential role of the external catalyst.
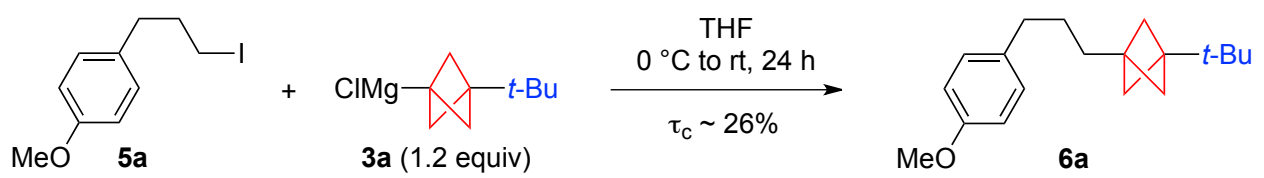

- Cobalt catalyzed cross-coupling $:^{24}$

\footnotetext{
${ }^{23}$ Note : if there is less than 1 equivalent of BCP Grignard reagent and if another Grignard reagent is present in the solution (either alkyl or aromatic Grignard reagent) the coupling between the mesylate and the non-BCP Grignard reagent will occur.

${ }^{24}$ Andersen, C.; Ferey, V.; Daumas, M.; Bernardelli, P.; Guérinot, A.; Cossy, J. Org. Lett. 2019, 21, 2285-2289.
} 
General procedure using $\mathbf{C o}(\mathrm{acac})_{2}$ as the catalyst: To the iodide $\mathbf{5 a}(0.22 \mathrm{mmol}, 1$ equiv) was added a solution of $\mathrm{Co}(\mathrm{acac})_{2}(2.016 \mathrm{mg}, 3.5 \mathrm{~mol} \%)$ in THF $(0.15 \mathrm{~mL})$, followed by the addition of TMEDA (0.22 mmol, $32.8 \mu \mathrm{L}, 1$ equiv) and THF $(0.15 \mathrm{~mL})$. The reaction mixture was cooled to $0{ }^{\circ} \mathrm{C}$, kept at rt or heated to $50{ }^{\circ} \mathrm{C}$. The Grignard reagent $3 \mathrm{a}$ (in solution in $\mathrm{Et}_{2} \mathrm{O}, 1.2$ equiv) was then added slowly by using a syringe pump $(0.52 \mathrm{mmol} / \mathrm{h})$ over $30 \mathrm{~min}$ or added through a rapid manual dropwise ( $\sim 3 \mathrm{~min}$ ). After addition of the Grignard reagent, the reaction mixture was stirred for the appropriated time at the corresponding temperature (see details in Table 4). The reaction was quenched with an aqueous saturated solution of $\mathrm{NH}_{4} \mathrm{Cl}$ and the aqueous phase was extracted with diethyl ether. The combined organic phases were dried over $\mathrm{MgSO}_{4}$, filtered and concentrated under reduced pressure.

After the addition of the Grignard reagent $3 \mathrm{a}$, when the reaction was achieved at $0{ }^{\circ} \mathrm{C}$, no conversion of the iodide 5a was observed after $30 \mathrm{~min}$ or $1 \mathrm{~h}$ ( Table 4, entry 1). Increasing the temperature to rt allowed an incomplete conversion of $\mathbf{5 a}$ and the coupling product $\mathbf{6 a}$ was not formed, the major product being the dehalogenated product 7 (Table 4, entry 3). When the reaction was realized during $16 \mathrm{~h}$, whether $3 \mathrm{a}$ is added over $30 \mathrm{~min}(0.52 \mathrm{mmol} / \mathrm{h})$ or over $3 \mathrm{~min}$ (rapid manual dropwise), full conversion of $\mathbf{5 a}$ was obtained, but the coupling product $\mathbf{6 a}$ was still not formed (Table 4, entries 3-4). The same results were obtained at $50^{\circ} \mathrm{C}$ (Table 4 , entries 5-6).

\section{Table 4}

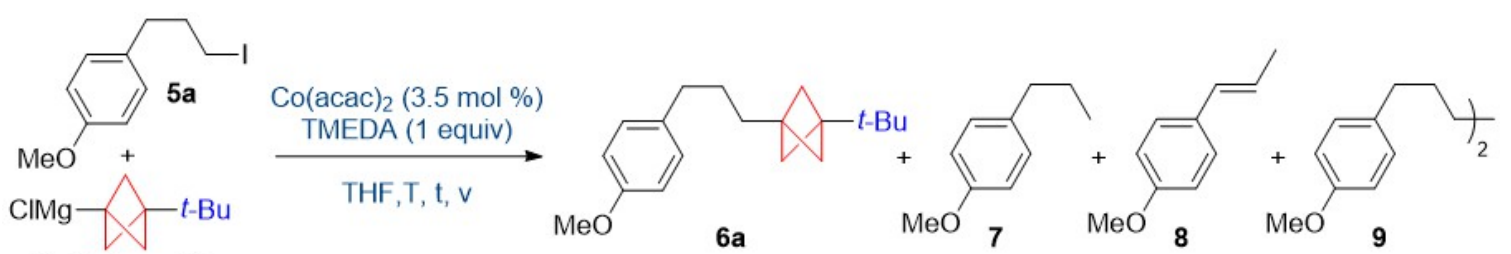

3a (1.2 equiv)

\begin{tabular}{ccccccccc} 
Entry & $\mathrm{T}$ & $\mathrm{t}(\mathrm{h})$ & $\boldsymbol{V}$ & $\begin{array}{c}\boldsymbol{\tau}_{\mathrm{c}} \\
(\%)\end{array}$ & $\mathbf{6 a}^{[\mathrm{a}]}$ & $\mathbf{7}^{\text {[a] }}$ & $\mathbf{8}^{\text {[a] }}$ & $\mathbf{9}^{\text {[a] }}$ \\
\hline 1 & $0{ }^{\circ} \mathrm{C}$ & 1 & $0.52 \mathrm{mmol} / \mathrm{h}$ & $\sim 0$ & - & - & - & - \\
2 & $\mathrm{rt}$ & 1 & $0.52 \mathrm{mmol} / \mathrm{h}$ & $<100$ & - & major & 0 & present \\
3 & $\mathrm{rt}$ & 16 & manual dropwise & 100 & - & major & traces & present \\
4 & $\mathrm{rt}$ & 16 & $0.52 \mathrm{mmol} / \mathrm{h}$ & 100 & - & major & traces & present \\
5 & $50^{\circ} \mathrm{C}$ & 16 & $0.52 \mathrm{mmol} / \mathrm{h}$ & 100 & - & major & traces & present \\
6 & $50^{\circ} \mathrm{C}$ & 16 & manual dropwise & 100 & - & major & traces & present \\
\hline
\end{tabular}

[a] Detected on the crude ${ }^{1} \mathrm{H}$ NMR.

- Copper-catalyzed cross-coupling :

(See General Procedure $\mathbf{E}$ when the reactions were run on $0.22 \mathrm{mmol}$ of $\mathbf{5}$. Note that $\mathrm{CuCl}$ was added as a solid instead of a $\mathrm{Li}_{2} \mathrm{CuCl}_{4}$ solution).

Since the use of $\mathrm{Co}(\mathrm{acac})_{2}$ seemed to be non-productive to form the desired coupling product, a test on iodide 5a was performed with another abundant, sustainable and eco-friendly metal salt, $\mathrm{CuCl}$. Pleasingly, with only $6 \mathrm{~mol} \%$ of $\mathrm{CuCl}$ and in the absence of any ligands or additives, the coupling product 6 a was exclusively formed and isolated with a yield of $88 \%$ after only 30 min at rt (Table 5 , entry 1). The use of the tosylate $\mathbf{5 b}$ resulted in the formation of $\mathbf{6 a}$ with an excellent yield of $99 \%$ (Table 5 , entry 2). ${ }^{25}$ As $\mathrm{CuCl}$ is insoluble in most organic solvents, the use of a commercially available

\footnotetext{
${ }^{25}$ The BCP Grignard reagent 3a can be preserved in a sealed tube to be used later on : the same reaction as in entry 2 has been done with 3a kept for 12 days with no deterioration in yield of $6 \mathbf{a}$ (quant.).
} 
$\mathrm{Li}_{2} \mathrm{CuCl}_{4}$ solution (1 M in THF) was advantageously considered from a practical point of view. Using a $\mathrm{Li}_{2} \mathrm{CuCl}_{4}$ solution (6 mol \%), an excellent yield of $93 \%$ in the coupling product 6 a was obtained (Table 5 , entry 3). As mesylates are more atom economical than the tosylates and easy to synthesize from alcohols, mesylate 5c was synthesized and involved in the coupling reaction with a BCP Grignard reagent in the presence of $\mathrm{Li}_{2} \mathrm{CuCl}_{4}(6 \mathrm{~mol} \%)$. Pleasingly, 6 a was isolated with a similar yield than the one obtained with the tosylate (94\%) (Table 5, entry 4). The $\mathrm{Li}_{2} \mathrm{CuCl}_{4}$ catalytic loading can be decreased to $3 \mathrm{~mol} \%$ without affecting the yield of $6 \mathbf{a}(93 \%)$ (Table 5, entry 5 ). However, using only 1 mol \% of $\mathrm{Li}_{2} \mathrm{CuCl}_{4}$ afforded the coupling product $6 \mathbf{a}$ with a slight decrease in the yield (87\%) (Table 5 , entry 6).

\section{Table 5}

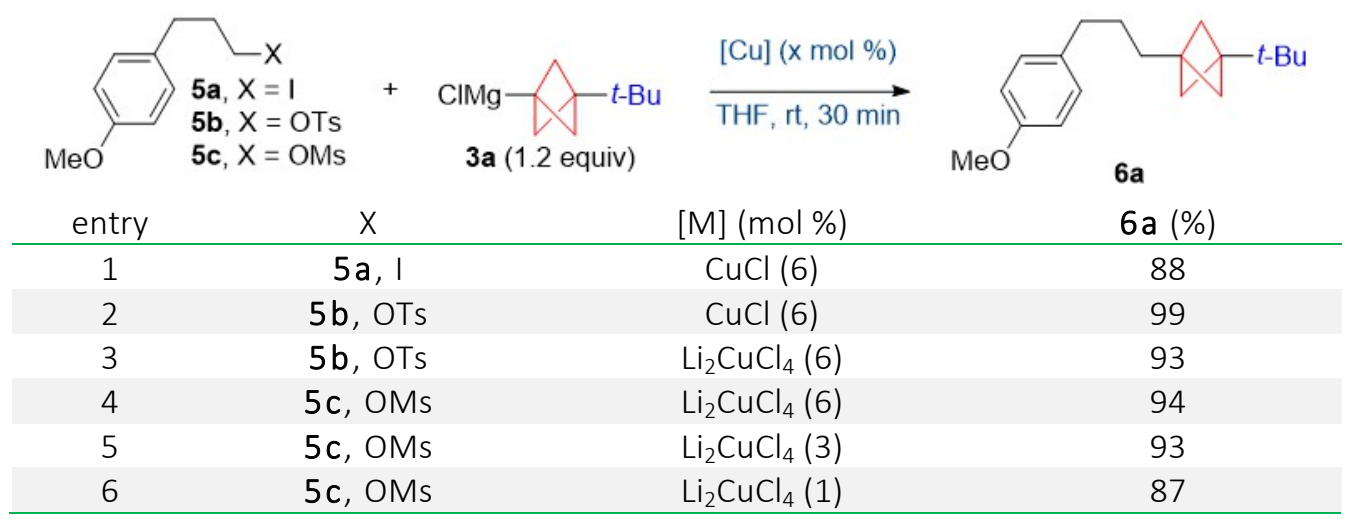

The reaction was successfully performed on $2 \mathrm{mmol}$ of $5 \mathrm{c}(489 \mathrm{mg})$.
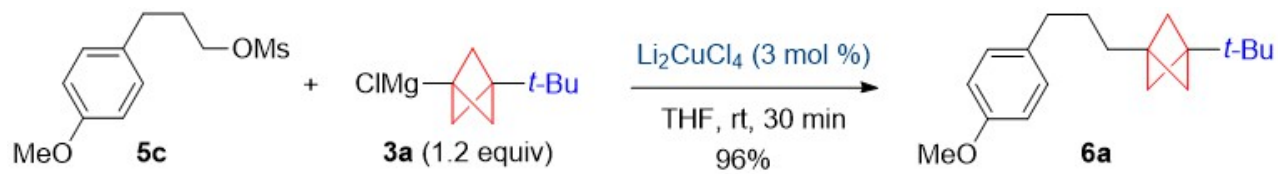

It is worth noting that when a mixture of a BCP Grignard reagent, substituted by an aromatic group at $\mathrm{C} 3$, and the aromatic Grignard was involved in the coupling, no coupling between the mesylate 5c and the residual aromatic Grignard reagent was observed. For example, when $\mathbf{5 c}$ was introduced in the presence of $\mathbf{3 d}$ and $\mathbf{4 a}$, no coupling reaction of $\mathbf{5 c}$ with $\mathbf{4 a}$ was observed (vide infra). The same observation was made with $\mathbf{3 e}$ and $\mathbf{3 f}$.
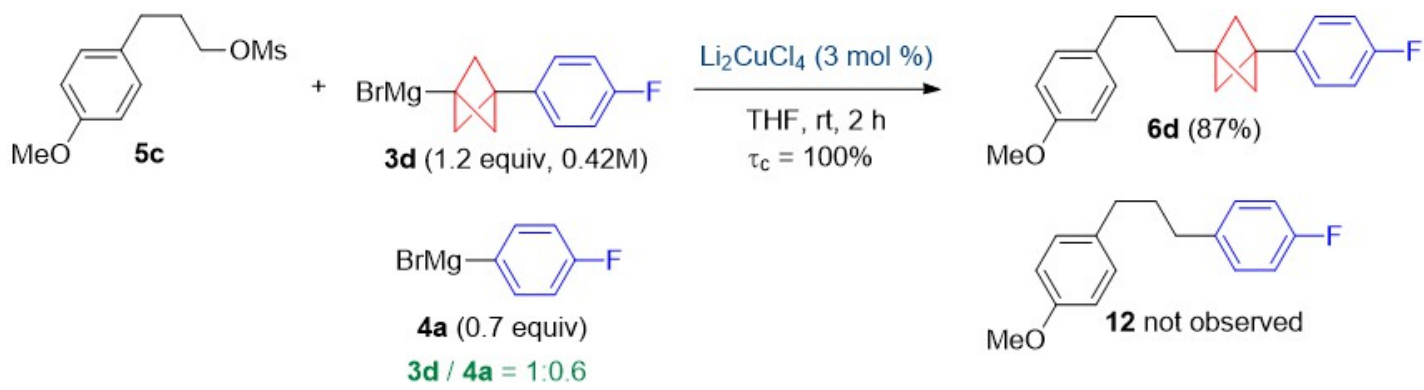

II.1.2. Scope of the cross-coupling between primary alkyl (pseudo)halides and BCPGrignard reagents 


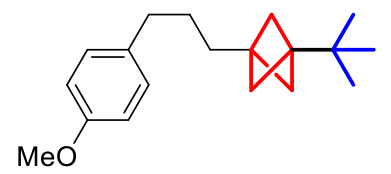

Bicyclo[1.1.1]pentane $\mathbf{6 a}$ was prepared according to Procedure $\mathbf{E}$ from methyl 3-(pmethoxyphenyl)propanesulfonate, $5 \mathbf{c}(60 \mathrm{mg}, 0.25 \mathrm{mmol})$ and Grignard reagent 3a $(0.67 \mathrm{~mL}, 0.44 \mathrm{M}$ in $\left.\mathrm{Et}_{2} \mathrm{O}\right)$. Purification by flash chromatography on silica gel $\left(\mathrm{PE} / \mathrm{Et}_{2} \mathrm{O}=50: 0.35\right)$ yielded bicyclo[1.1.1]pentane $6 \mathrm{a}(62 \mathrm{mg}, 0.23 \mathrm{mmol}, 93 \%)$ as a colourless oil.

Formula: $\mathrm{C}_{19} \mathrm{H}_{28} \mathrm{O}$

Mass: $272.4 \mathrm{~g} \cdot \mathrm{mol}^{-1}$

IR (neat): 1613, 1584, 1512, 1460, 1443, 1392, 1361, 1300, 1269, 1245, 1194, 1176, 1118, 1094, 1040, $951 \mathrm{~cm}^{-1}$

${ }^{1} \mathrm{H}$ NMR $\left(400 \mathrm{MHz}, \mathrm{CDCl}_{3}\right) \delta 7.10(\mathrm{~d}, J=8.4 \mathrm{~Hz}, 2 \mathrm{H}), 6.84(\mathrm{~d}, J=8.5 \mathrm{~Hz}, 2 \mathrm{H}), 3.80(\mathrm{~s}, 3 \mathrm{H}), 2.56(\mathrm{t}, J=$ $7.6 \mathrm{~Hz}, 2 \mathrm{H}), 1.60-1.49(\mathrm{~m}, 2 \mathrm{H}), 1.49-1.41(\mathrm{~m}, 2 \mathrm{H}), 1.39(\mathrm{~s}, 6 \mathrm{H}), 0.83(\mathrm{~s}, 9 \mathrm{H})$

${ }^{13} \mathrm{C}$ NMR $\left(100 \mathrm{MHz}, \mathrm{CDCl}_{3}\right) \delta 157.7,135.1,129.3$ (2C), 113.7 (2C), 55.3, 47.7, 46.5 (3C), 36.7, 35.3, 31.7, 29.5, 29.0, $26.0(3 \mathrm{C})$

MS (EI) m/z: 272 (2), 173 (3), 135 (12), 134 (100), 121 (30), 91 (7), 77 (6), 57 (5), 55 (7)

HRMS (ESI) m/z: $[\mathrm{M}+\mathrm{H}]^{+}$Calcd for $\mathrm{C}_{19} \mathrm{H}_{29} \mathrm{O} 273.2213$, Found 273.2213

1-isoPropyl-3-[3(p-methoxyphenyl)propyl]bicyclo[1.1.1]pentane, $\mathbf{6 b}^{\mathbf{2 6}}$

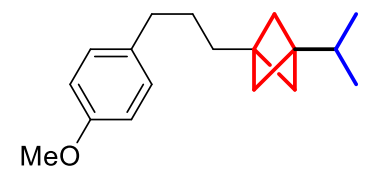

Bicyclo[1.1.1]pentane $\mathbf{6 b}$ was prepared according to Procedure $\mathbf{E}$ from methyl 3-(pmethoxyphenyl)propanesulfonate, $5 \mathbf{c}(54 \mathrm{mg}, 0.22 \mathrm{mmol})$ and Grignard reagent $3 \mathbf{b}(0.59 \mathrm{~mL}, 0.45 \mathrm{M}$ in $\left.\mathrm{Et}_{2} \mathrm{O}\right)$. Purification by flash chromatography on silica gel $\left(\mathrm{PE} / \mathrm{Et}_{2} \mathrm{O}=50: 0.35\right)$ allowed the isolation of bicyclo[1.1.1]pentane $6 \mathrm{~b}(49 \mathrm{mg}, 0.19 \mathrm{mmol}, 87 \%)$ as a colourless oil.

Formula: $\mathrm{C}_{18} \mathrm{H}_{26} \mathrm{O}$

Mass: $258.4 \mathrm{~g} \cdot \mathrm{mol}^{-1}$

IR (neat): 1613, 1584, 1511, 1464, 1381, 1362, 1300, 1259, 1245, 1203, 1176, 1156, 1117, 1096, 1039 $\mathrm{cm}^{-1}$

${ }^{1} \mathrm{H}$ NMR $\left(400 \mathrm{MHz}, \mathrm{CDCl}_{3}\right) 7.10(\mathrm{~d}, J=8.6 \mathrm{~Hz}, 2 \mathrm{H}), 6.83(\mathrm{~d}, J=8.6 \mathrm{~Hz}, 2 \mathrm{H}), 3.79(\mathrm{~s}, 3 \mathrm{H}), 2.60-2.55$ $(\mathrm{t}, J=7.4 \mathrm{~Hz}, 2 \mathrm{H}), 1.62(\mathrm{~m}, 1 \mathrm{H}), 1.58-1.49(\mathrm{~m}, 2 \mathrm{H}), 1.49-1.41(\mathrm{~m}, 2 \mathrm{H}), 1.38(\mathrm{~s}, 6 \mathrm{H}), 0.80(\mathrm{~d}, J=6.8$ $\mathrm{Hz}, 6 \mathrm{H})$

${ }^{13} \mathrm{C}$ NMR $\left(100 \mathrm{MHz}, \mathrm{CDCl}_{3}\right) \delta$ 157.7, 135.1, $129.3(2 \mathrm{C}), 113.7$ (2C), 55.3, 47.7 (3C), 44.4, 38.3, 35.3, $31.8,29.0,28.7,18.9(2 \mathrm{C})$

MS (EI) m/z: 258 (3), 173 (3), 135 (12), 134 (100), 122 (3), 121 (32), 119 (5), 109 (3), 91 (7), 79 (4), 78 (4), 77 (7), 67 (4), 65 (3).

1-Cyclopentyl-3-[3-(p-methoxyphenyl)propyl]bicyclo[1.1.1]pentane, 6c

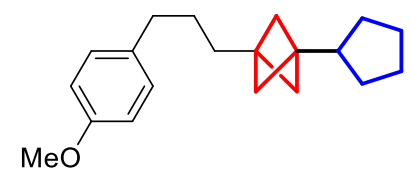

\footnotetext{
${ }^{26}$ Due to ionization difficulties, no HRMS analysis could be recorded. Unfortunately, the CoVid crisis prevented us from submitting the samples to an elemental analysis platform.
} 
Bicyclo[1.1.1]pentane 6c was prepared according to Procedure $\mathbf{E}$ from methyl 3-(pmethoxyphenyl)propanesulfonate, $5 \mathrm{c}(54 \mathrm{mg}, 0.22 \mathrm{mmol})$ and Grignard reagent $3 \mathrm{c}(0.58 \mathrm{~mL}, 0.46 \mathrm{M}$ in $\left.\mathrm{Et}_{2} \mathrm{O}\right)$. Purification by flash chromatography on silica gel $\left(\mathrm{PE} / \mathrm{Et}_{2} \mathrm{O}=50: 0.35\right)$ allowed the isolation of bicyclo[1.1.1]pentane $6 \mathrm{c}(57 \mathrm{mg}, 0.20 \mathrm{mmol}, 91 \%)$ as a colourless oil.

Formula: $\mathrm{C}_{20} \mathrm{H}_{28} \mathrm{O}$

Mass: $284.4 \mathrm{~g} \cdot \mathrm{mol}^{-1}$

IR (neat): 1613, 1583, 1511, 1452, 1300, 1259, 1244, 1203, 1175, 1117, 1039, $933 \mathrm{~cm}^{-1}$

${ }^{1} \mathrm{H}$ NMR $\left(400 \mathrm{MHz}, \mathrm{CDCl}_{3}\right) \delta 7.10(\mathrm{~d}, J=8.6 \mathrm{~Hz}, 2 \mathrm{H}), 6.83(\mathrm{~d}, J=8.6 \mathrm{~Hz}, 2 \mathrm{H}), 3.79(\mathrm{~s}, 3 \mathrm{H}), 2.55(\mathrm{t}$, $J=7.6 \mathrm{~Hz}, 2 \mathrm{H}), 1.88$ (quint $\left.{ }_{\mathrm{app}}, J=7.52 \mathrm{~Hz}, 1 \mathrm{H}\right), 1.59-1.41(\mathrm{~m}, 10 \mathrm{H}), 1.39(\mathrm{~s}, 6 \mathrm{H}), 1.27-1.18(\mathrm{~m}, 2 \mathrm{H})$ ${ }^{13} \mathrm{C}$ NMR $\left(100 \mathrm{MHz}, \mathrm{CDCl}_{3}\right) \delta 157.7,135.1,129.3(2 \mathrm{C}), 113.7$ (2C), 55.3, 48.6 (3C), 42.3, 40.6, 39.3, 35.3, 31.8, $29.2(2 \mathrm{C}), 29.4,25.8(2 \mathrm{C})$

MS (EI) m/z: 184 (2), 173 (3), 135 (15), 134 (100), 122 (3), 121 (30), 119 (4), 107 (3), 95 (3), 93 (3), 91 (7), 79 (5), 78 (3), 77 (6), 55 (4)

1-(p-Fluorophenyl)-3-[3-(o-methoxyphenyl)propyl]bicyclo[1.1.1]pentane, 6d

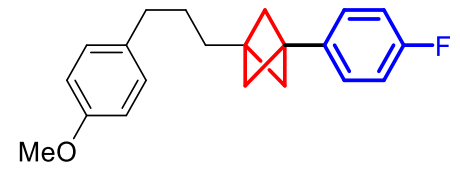

Bicyclo[1.1.1]pentane $\mathbf{6 d}$ was prepared according to Procedure $\mathbf{E}$ from methyl 3-(pmethoxyphenyl)propanesulfonate, $5 \mathbf{c}(54 \mathrm{mg}, 0.22 \mathrm{mmol})$ and Grignard reagent $3 \mathbf{d}(0.63 \mathrm{~mL}, 0.42 \mathrm{M}$ in $\left.\mathrm{Et}_{2} \mathrm{O}\right)$. Purification by flash chromatography on silica gel $\left(\mathrm{PE} / \mathrm{Et}_{2} \mathrm{O}=50: 0.35\right)$ allowed the isolation of bicyclo[1.1.1]pentane $\mathbf{6 d}(60 \mathrm{mg}, 0.19 \mathrm{mmol}, 87 \%)$ as a colourless oil.

Formula: $\mathrm{C}_{21} \mathrm{H}_{23} \mathrm{FO}$

Mass: $310.4 \mathrm{~g} \cdot \mathrm{mol}^{-1}$

IR (neat): 1611, 1584, 1511, 1463, 1442, 1300, 1269, 1245, 1219, 1177, 1152, 1132, 1109, 1087, 1037 , $1015,907 \mathrm{~cm}^{-1}$

${ }^{1} \mathrm{H}$ NMR $\left(400 \mathrm{MHz}, \mathrm{CDCl}_{3}\right) \delta 7.22-7.10(\mathrm{~m}, 4 \mathrm{H}), 6.98\left(\mathrm{t}_{\mathrm{app}}, J=8.8 \mathrm{~Hz}, 2 \mathrm{H}\right), 6.87(\mathrm{~d}, J=8.4 \mathrm{~Hz}, 2 \mathrm{H})$, $3.82(\mathrm{~s}, 3 \mathrm{H}), 2.61(\mathrm{t}, J=7.1 \mathrm{~Hz}, 2 \mathrm{H}), 1.90(\mathrm{~s}, 6 \mathrm{H}), 1.69-1.52(\mathrm{~m}, 4 \mathrm{H})$

${ }^{13} \mathrm{C}$ NMR $\left(100 \mathrm{MHz}, \mathrm{CDCl}_{3}\right) \delta 161.6(\mathrm{~d}, J=243.9 \mathrm{~Hz}), 157.8,137.5,134.8,129.3(2 \mathrm{C}), 127.6(\mathrm{~d}$, $J=7.8 \mathrm{~Hz}, 2 \mathrm{C}), 114.7$ (d, $J=21.1 \mathrm{~Hz}, 2 \mathrm{C}), 113.8(2 \mathrm{C}), 55.3,52.3(3 \mathrm{C}), 41.1,38.8,35.2,31.3,29.0$

${ }^{19} \mathrm{~F}$ NMR $\left(376 \mathrm{MHz}, \mathrm{CDCl}_{3}\right) \delta-116.88$

HRMS (ESI) m/z: [M+H] $]^{+}$Calcd for $\mathrm{C}_{21} \mathrm{H}_{24} \mathrm{FO} 311.1806$, Found 311.1805

\section{1-[4-(Benzyloxy)butyl]-3-(tert-butyl)bicyclo[1.1.1]pentane, 6e}

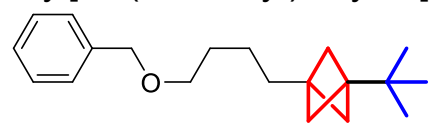

Bicyclo[1.1.1]pentane $\mathbf{6 e}$ was prepared according to Procedure $\mathbf{E}$ from methyl 4(benzyloxy)butanesulfonate 5d (57 mg, $0.22 \mathrm{mmol})$ and Grignard reagent $3 \mathbf{a}\left(0.63 \mathrm{~mL}, 0.42 \mathrm{M}\right.$ in $\left.\mathrm{Et}_{2} \mathrm{O}\right)$. Purification by flash chromatography on silica gel $\left(\mathrm{PE} / \mathrm{Et}_{2} \mathrm{O}=97: 3\right)$ allowed the isolation of bicyclo[1.1.1]pentane $6 \mathrm{e}(54 \mathrm{mg}, 0.19 \mathrm{mmol}, 86 \%)$ as a colourless oil.

Formula: $\mathrm{C}_{20} \mathrm{H}_{30} \mathrm{O}$

Mass: $286.5 \mathrm{~g} \cdot \mathrm{mol}^{-1}$

IR (neat): 1722, 1496, 1475, 1455, 1392, 1361, 1273, 1224, 1195, 1101, $1028 \mathrm{~cm}^{-1}$

${ }^{1} \mathrm{H}$ NMR $\left(400 \mathrm{MHz}, \mathrm{CDCl}_{3}\right) \delta$ 7.28- $7.25(\mathrm{~m}, 4 \mathrm{H}), 7.20(\mathrm{~m}, 1 \mathrm{H}), 4.42(\mathrm{~s}, 2 \mathrm{H}), 3.38(\mathrm{t}, J=6.7 \mathrm{~Hz}, 2 \mathrm{H})$, 1.54 (quint $\left._{\text {app }}, J=7.1 \mathrm{~Hz}, 2 \mathrm{H}\right), 1.38-1.30(\mathrm{~m}, 2 \mathrm{H}), 1.29(\mathrm{~s}, 6 \mathrm{H}), 1.28-1.20(\mathrm{~m}, 2 \mathrm{H}), 0.74(\mathrm{~s}, 9 \mathrm{H})$

${ }^{13} \mathrm{C}$ NMR $\left(100 \mathrm{MHz}, \mathrm{CDCl}_{3}\right) \delta 138.8,128.4$ (2C), 127.7 (2C), 127.5, 72.9, 70.6, 47.6, 46.5 (3C), 36.7, $32.0,30.0,29.5,26.0(3 \mathrm{C}), 23.4$ 
MS (EI) m/z: 271 (1), 195 (1), 123 (11), 121 (15), 107 (11), 95 (16), 93 (14), 91 (100), 83 (23), 81 (16), 79 (11), 69 (11), 67 (10), 57 (35), 55 (23)

HRMS (ESI) m/z: [M+Na] $]^{+}$Calcd for $\mathrm{C}_{20} \mathrm{H}_{30} \mathrm{ONa} 309.2189$, Found 309.2188

1-[6-Methylen)-2,3-dihydro-2H-pyran]-3-(tert-butyl)bicyclo[1.1.1]pentane, $6 \mathbf{f}$

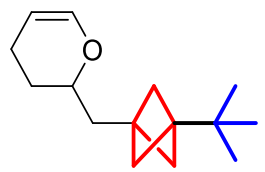

Bicyclo[1.1.1]pentane 6f was prepared according to Procedure E from methyl (3,4-dihydro-2H-pyran-2-

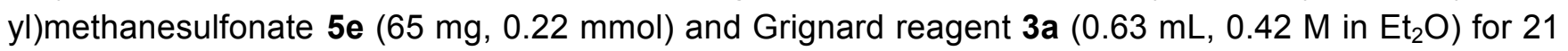
h. Purification by flash chromatography on silica gel (gradient of elution $\mathrm{PE} / \mathrm{Et}_{2} \mathrm{O}=96: 4$ to 80:20) allowed the isolation of bicyclo[1.1.1]pentane $6 \mathrm{f}(16 \mathrm{mg}, 0.070 \mathrm{mmol}, 40 \%(52 \% \mathrm{brsm}))$ as a yellowish oil.

Formula: $\mathrm{C}_{15} \mathrm{H}_{24} \mathrm{O}$

Mass: $220.4 \mathrm{~g} \cdot \mathrm{mol}^{-1}$

IR (neat): 1650, 1474, 1460, 1391, 1361, 1271, 1254, 1238, 1224, 1196, 1065, 1031, 977, $927 \mathrm{~cm}^{-1}$

${ }^{1} \mathrm{H}$ NMR $\left(400 \mathrm{MHz}, \mathrm{CDCl}_{3}\right) \delta 6.34(\mathrm{br} \mathrm{dt}, J=6.08,1.58 \mathrm{~Hz}, 1 \mathrm{H}), 4.64(\mathrm{~m}, 1 \mathrm{H}), 3.80(\mathrm{~m}, 1 \mathrm{H}), 2.10(\mathrm{~m}$, $1 \mathrm{H}), 1.94(\mathrm{~m}, 1 \mathrm{H}), 1.87(\mathrm{~m}, 1 \mathrm{H}), 1.81\left(\mathrm{dd}, J_{\mathrm{AB}}=14.4,6.9 \mathrm{~Hz}, 1 \mathrm{H}\right), 1.61\left(\mathrm{dd}, J_{\mathrm{AB}}=14.3,5.7 \mathrm{~Hz}, 1 \mathrm{H}\right)$, $1.56(\mathrm{~m}, 1 \mathrm{H}), 1.47(\mathrm{~s}, 6 \mathrm{H}), 0.82(\mathrm{~s}, 9 \mathrm{H})$

${ }^{13} \mathrm{C}$ NMR $\left(100 \mathrm{MHz}, \mathrm{CDCl}_{3}\right) \delta 143.9,100.3,74.2,48.4,47.5$ (3C), 37.5, 34.5, 29.5, 28.3, 26.0 (3C), 19.8

MS (EI) m/z: 220 (2), 121 (18), 107 (20), 95 (11), 93 (19), 91 (15), 83 (100), 81 (28), 79 (18), 67 (13), 57 (40), 55 (52)

HRMS (ESI) m/z: $[\mathrm{M}+\mathrm{H}]^{+}$Calcd for $\mathrm{C}_{15} \mathrm{H}_{25} \mathrm{O}[\mathrm{M}+\mathrm{H}]^{+} 221.1900$, Found 221.1900

1-[3-(p-Bromophenyl)propyl]-3-(tert-butyl)bicyclo[1.1.1]pentane, $6 \mathbf{g}$

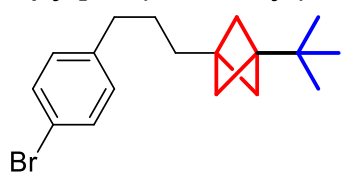

Bicyclo[1.1.1]pentane $\mathbf{6 g}$ was prepared according to Procedure $\mathbf{E}$ from methyl 3-(pbromophenyl)propanesulfonate $\mathbf{5 f}(65 \mathrm{mg}, 0.22 \mathrm{mmol})$ and Grignard reagent $3 \mathbf{a}(0.63 \mathrm{~mL}, 0.42 \mathrm{M}$ in $\mathrm{Et}_{2} \mathrm{O}$ ). Purification by flash chromatography on silica gel (PE 100\%) yielded bicyclo[1.1.1]pentane $\mathbf{6 g}$ (66 mg, $0.20 \mathrm{mmol}, 93 \%$ ) as an off-white solid.

Formula: $\mathrm{C}_{18} \mathrm{H}_{25} \mathrm{Br}$

Mass: $321.3 \mathrm{~g} \cdot \mathrm{mol}^{-1}$

mp: $45-47^{\circ} \mathrm{C}$

IR (neat): $1488,1460,1447,1402,1392,1361,1276,1224,1195,1073,1011 \mathrm{~cm}^{-1}$

${ }^{1} \mathrm{H}$ NMR $\left(400 \mathrm{MHz}, \mathrm{CDCl}_{3}\right) \delta 7.40(\mathrm{~d}, J=8.4 \mathrm{~Hz}, 2 \mathrm{H}), 7.05(\mathrm{~d}, J=8.4 \mathrm{~Hz}, 2 \mathrm{H}), 2.57(\mathrm{t}, J=7.6 \mathrm{~Hz}, 2 \mathrm{H})$, $1.63-1.49(\mathrm{~m}, 2 \mathrm{H}), 1.49-1.42(\mathrm{~m}, 2 \mathrm{H}), 1.40(\mathrm{~s}, 6 \mathrm{H}), 0.83(\mathrm{~s}, 9 \mathrm{H})$

${ }^{13} \mathrm{C}$ NMR $\left(100 \mathrm{MHz}, \mathrm{CDCl}_{3}\right) \delta 141.8,131.3(2 \mathrm{C}), 130.3(2 \mathrm{C}), 119.4,47.7,46.5(3 \mathrm{C}), 36.6,35.6,31.6$, 29.5, 28.6, $26.0(3 \mathrm{C})$

MS (EI) m/z: 307 (1), 305 (1), 184 (65), 182 (65), 171 (25), 169 (25), 138 (15), 124 (10), 123 (100), 104 (11), 103 (10), 95 (27), 91 (14), 90 (16), 85 (10), 84 (10), 83 (44), 82 (14), 81 (70), 79 (14), 77 (14), 69 (11), 67 (32), 57 (41), 55 (47)

HRMS (ESI) m/z: $[\mathrm{M}+\mathrm{H}]^{+}$Calcd for $\mathrm{C}_{18} \mathrm{H}_{26} \mathrm{Br} 320.1134$ and 322.1114, Found 320.1134 and 322.1114 
1-(Methyl hexanoate)-3-(tert-butyl)bicyclo[1.1.1]pentane, $\mathbf{6 h}$

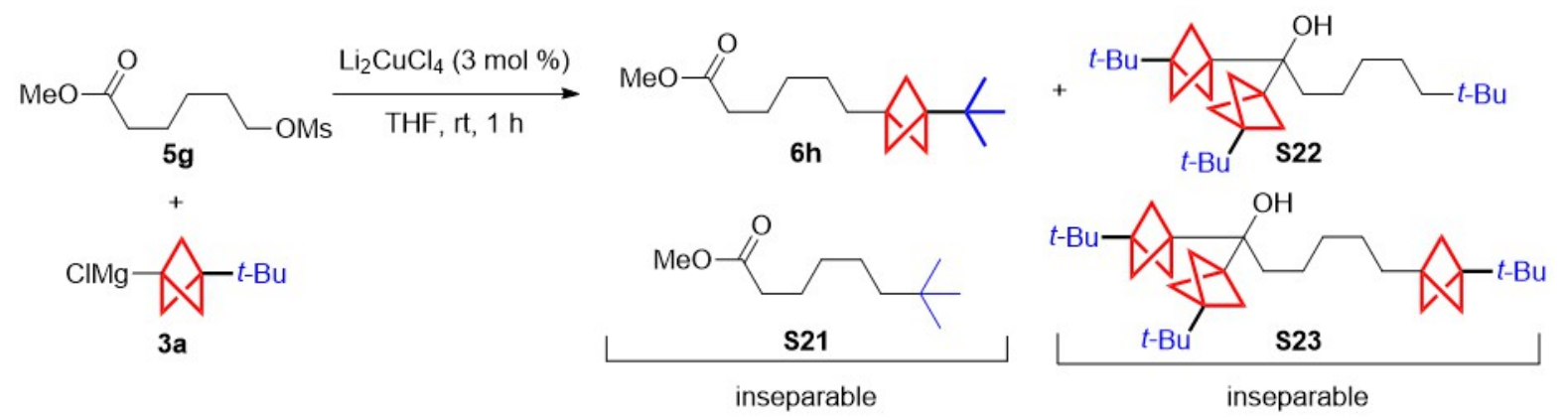

Bicyclo[1.1.1]pentane $\mathbf{6 h}$ was prepared according to Procedure $\mathbf{E}$ from methyl 6(methanesulfonyloxy)hexanoate $\mathbf{5 g}(49 \mathrm{mg}, 0.22 \mathrm{mmol})$ and Grignard reagent $3 \mathbf{a}(0.63 \mathrm{~mL}, 0.42 \mathrm{M}$ in $\mathrm{Et}_{2} \mathrm{O}$ ). Purification by flash chromatography on silica gel (gradient of elution $\mathrm{PE} \mathrm{Et}_{2} \mathrm{O}=98: 2$ to $90: 10$ ) yielded bicyclo[1.1.1]pentane $6 \mathrm{~h}(33 \mathrm{mg}, 0.13 \mathrm{mmol}, 59 \%)$ contaminated with $\mathbf{S} 21$ (7 $\mathrm{mg}, 0.04 \mathrm{mmol}$, $17 \%$ ) as a colourless oil and as a mixture of $\mathbf{S} 22$ and $\mathbf{S} 23$ (ratio not determined, $12 \mathrm{mg}, \sim 0.03 \mathrm{mmol}$, $\sim 13 \%)$.

Formula: $\mathrm{C}_{16} \mathrm{H}_{28} \mathrm{O}_{2}$

Mass: $252.4 \mathrm{~g} \cdot \mathrm{mol}^{-1}$

IR (neat): 1742, 1461, 1436, 1393, 1361, 1270, 1226, 1195, 1167, 1118, $1067 \mathrm{~cm}^{-1}$

${ }^{1} \mathrm{H}$ NMR $\left(400 \mathrm{MHz}, \mathrm{CDCl}_{3}\right) \delta 3.65(\mathrm{~s}, 3 \mathrm{H}), 2.29(\mathrm{t}, \mathrm{J}=7.5 \mathrm{~Hz}, 2 \mathrm{H}), 1.66-1.55(\mathrm{~m}, 2 \mathrm{H}), 1.44-1.35(\mathrm{~m}$, $2 \mathrm{H}), 1.35(\mathrm{~s}, 6 \mathrm{H}), 1.33-1.18(\mathrm{~m}, 4 \mathrm{H}), 0.80(\mathrm{~s}, 9 \mathrm{H})$

${ }^{13} \mathrm{C}$ NMR $\left(100 \mathrm{MHz}, \mathrm{CDCl}_{3}\right) \delta 174.3,51.4,47.5,46.4(3 \mathrm{C}), 36.6,34.1,31.8,29.4,29.3,26.3,25.9(3 \mathrm{C})$, 25.0

MS (EI) m/z: 237 (16), 163 (42), 145 (12), 135 (29), 124 (10), 123 (100), 121 (38), 109 (22), 107 (22), 97 (10), 95 (42), 93 (30), 91 (14), 85 (12), 84 (19), 83 (67), 82 (20), 81 (76), 80 (11), 79 (35), 77 (10), 69 (24), 67 (76), 59 (16), 57 (58), 55 (83), 53 (12)

HRMS (ESI) m/z: $[\mathrm{M}+\mathrm{Na}]^{+}$Calcd for $\mathrm{C}_{16} \mathrm{H}_{28} \mathrm{O}_{2} \mathrm{Na} 275.1982$, Found 275.1981

1-(2,2-Dimethylhexanenitrile)-3-(tert-butyl)bicyclo[1.1.1]pentane, $6 \mathbf{i}$

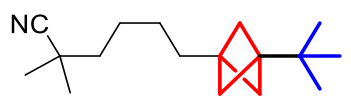

Bicyclo[1.1.1]pentane $\mathbf{6 i}$ was prepared according to Procedure $\mathbf{E}$ from 6-bromo-2,2-dimethylhexanenitrile $5 \mathrm{~h}(46 \mathrm{mg}, 0.22 \mathrm{mmol})$ and Grignard reagent 3a $(0.59 \mathrm{~mL}, 0.45 \mathrm{M}$ in $\left.\mathrm{Et}_{2} \mathrm{O}\right)$. Purification by flash chromatography on silica gel $\left(\mathrm{PE} / \mathrm{Et}_{2} \mathrm{O}=99: 1\right)$ yielded bicyclo[1.1.1]pentane $6 \mathbf{i}(48 \mathrm{mg}, 0.19 \mathrm{mmol}, 88 \%)$ as a white solid.

Formula: $\mathrm{C}_{17} \mathrm{H}_{29} \mathrm{~N}$

Mass: $247.4 \mathrm{~g} \cdot \mathrm{mol}^{-1}$

mp: $46-47^{\circ} \mathrm{C}$

IR (neat): 1472, 1461, 1392, 1361, 1272, 1223, 1195, 1058, $943 \mathrm{~cm}^{-1}$

${ }^{1} \mathrm{H}$ NMR $\left(400 \mathrm{MHz}, \mathrm{CDCl}_{3}\right) \delta 1.54-1.40(\mathrm{~m}, 6 \mathrm{H}), 1.37(\mathrm{~s}, 6 \mathrm{H}), 1.33(\mathrm{~s}, 6 \mathrm{H}), 1.30-1.23(\mathrm{~m}, 2 \mathrm{H}), 0.81$ $(\mathrm{s}, 9 \mathrm{H})$

${ }^{13} \mathrm{C}$ NMR $\left(100 \mathrm{MHz}, \mathrm{CDCl}_{3}\right) \delta 125.3,47.6,46.5$ (3C), 41.2, 36.6, 32.5, 31.9, 29.5, $26.8(2 \mathrm{C}+1 \mathrm{C}), 26.0$ (3C), 25.5

MS (EI) m/z: 246 (1), 232 (18), 190 (41), 173 (10), 134 (13), 131 (12), 124 (14), 123 (100), 121 (13), 119 (12), 109 (16), 107 (21), 105 (12), 95 (38), 93 (24), 91 (19), 84 (14), 83 (81), 82 (22), 81 (67), 79 (32), 77 (13), 69 (29), 68 (10), 67 (65), 57 (57), 55 (94), 53 (16)

HRMS (ESI) m/z: [M+Na] $]^{+}$Calcd for $\mathrm{C}_{17} \mathrm{H}_{29} \mathrm{NNa} 270.2192$, Found 270.2194 
II.2.1. Optimization of the cross-coupling between secondary alkyl (pseudo)halides and alkyl-BCP Grignard reagents

General procedure : To mesylate $\mathbf{5 i}$ or tosylate $\mathbf{5} \mathbf{j}$ were added a copper salt as a solid $\left(\mathrm{CuCl}_{2}\right.$, Cul, $\mathrm{CuCl}$ or $\mathrm{CuCN})$ or as a solution in THF $\left(\mathrm{Li}_{2} \mathrm{CuCl}_{4}, 1 \mathrm{M}\right.$ in THF) and additional THF as well as the additive, if necessary. The reaction mixture was either kept at $\mathrm{rt}$ or heated at $40{ }^{\circ} \mathrm{C}$ before adding the Grignard reagent $3 \mathbf{a}$ ( $\mathrm{Et}_{2} \mathrm{O}$ solution, 1.4 equiv) dropwise (manually). The reaction mixture was then stirred at the corresponding temperature for $3 \mathrm{~h}$ to $3.5 \mathrm{~h}$ before being quenched with a saturated aqueous solution of $\mathrm{NH}_{4} \mathrm{Cl}$ and the aqueous phase was extracted with diethyl ether (twice). The combined organic phases were dried over $\mathrm{MgSO}_{4}$, filtered and concentrated under reduced pressure. Purification by flash chromatography on silica gel afforded the desired coupling product.

Starting from the mesylate $\mathbf{5 i}$, alcohol 10 was always the major product formed regardless the conditions used and was the only product formed in the absence of any catalyst.

\begin{tabular}{|c|c|c|c|c|c|}
\hline \multirow[b]{2}{*}{ Entry } & $\underset{\substack{\mathbf{5 i} \\
\text { (1 equiv) }}}{\substack{3 \mathrm{a} \\
\text { (1.4 equiv) }}}$ & $\underset{\substack{\mathrm{THF} \\
\mathrm{T}, 3 \mathrm{~h} \\
\tau_{\mathrm{c}}=100 \%}}{\stackrel{\mathrm{Cu}]}{\longrightarrow}}$ Table & \multirow[b]{2}{*}{$6 \mathbf{j}^{[\mathrm{a]}}$} & 10 & $\sqrt[30 c N]{\square}$ \\
\hline & Conditions & $\mathrm{T}$ & & $10^{[a]}$ & $11^{[a]}$ \\
\hline 1 & - & $\mathrm{rt}$ & - & Only & - \\
\hline $2^{27}$ & $\begin{array}{c}\mathrm{CuCl}_{2}(6 \mathrm{~mol} \%) \\
\text { 1-phenyl-1-propyne (1 } \\
\text { equiv) }\end{array}$ & rt or $40^{\circ} \mathrm{C}$ & present & Major & present \\
\hline $3^{28}$ & $\begin{array}{c}\text { Cul }(6 \text { mol \%) } \\
\text { TMEDA ( } 1 \text { equiv) } \\
\text { LiOMe ( } 1 \text { equiv) }\end{array}$ & rt or $40^{\circ} \mathrm{C}$ & present & Major & present \\
\hline $4^{27}$ & $\begin{array}{c}\mathrm{CuCl}_{2}(6 \mathrm{~mol} \%) \\
\text { isoprene (1 equiv) }\end{array}$ & rt or $40^{\circ} \mathrm{C}$ & present & Major & present \\
\hline 5 & $\begin{array}{l}\text { CuCl (6 mol \%) } \\
\text { TMEDA ( } 1 \text { equiv) }\end{array}$ & rt or $40^{\circ} \mathrm{C}$ & present & Major & present \\
\hline 6 & $\mathrm{CuCN}(6 \mathrm{~mol} \%)$ & rt or $40^{\circ} \mathrm{C}$ & - & Major & traces \\
\hline 7 & $\mathrm{Li}_{2} \mathrm{CuCl}_{4}(6 \mathrm{~mol} \%)$ & $\begin{array}{c}\mathrm{rt} \\
40^{\circ} \mathrm{C}\end{array}$ & $\begin{array}{c}\text { present } \\
(18 \%)\end{array}$ & $\begin{array}{l}\text { Major } \\
\text { Major }\end{array}$ & $\begin{array}{c}\text { present } \\
(6 \%)\end{array}$ \\
\hline
\end{tabular}

[a] Detected on the crude ${ }^{1} \mathrm{H}$ NMR.

Starting from the tosylate $\mathbf{5 j}$, the alcohol $\mathbf{1 0}$ was the minor product. Better conversion of $\mathbf{5 j}$ was obtained at $40{ }^{\circ} \mathrm{C}$ in comparison to rt. The best results were obtained with $\mathrm{Li}_{2} \mathrm{CuCl}_{4}$ and additional ligand (TMEDA, 1-phenyl-1-propyne, isoprene) did not improve the ratio of coupling product $\mathbf{6 j} /$ elimination product $\mathbf{1 1}$, the elimination product being always present in significant quantities $(\mathbf{6 j} / \mathbf{1 1}=$ 1:0.6).

\footnotetext{
${ }^{27}$ Iwasaki, T.; Imanishi, R.; Shimizu, R.; Kuniyasu, H.; Terao, J.; Kambe, N. J. Org. Chem. 2014, 79, 8522-8532.

${ }^{28}$ Yang, C.-T.; Zhang, Z.-Q.; Liang, J.; Liu, J.-H.; Lu, X.-Y.; Chen, H.-H.; Liu, L. J. Am. Chem. Soc. 2012, 134, $11124-11127$.
} 


\section{Table 7}

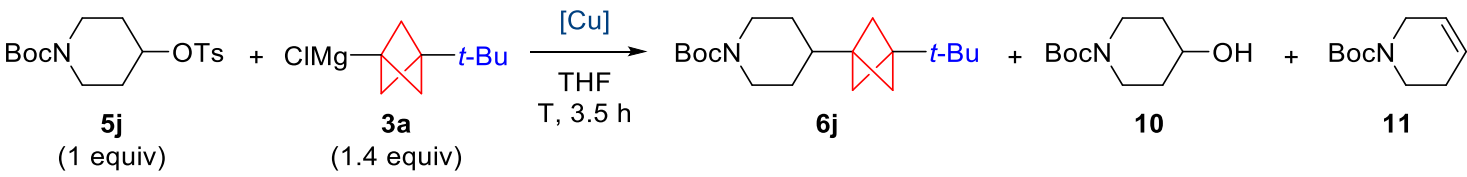

\begin{tabular}{|c|c|c|c|c|c|c|}
\hline Entry & Conditions & $\mathrm{T}$ & $\begin{array}{c}\tau_{c} \\
(\%)\end{array}$ & $\begin{array}{c}\text { ratio } \\
\mathbf{6 j} / 10 / 11^{(a)}\end{array}$ & $\begin{array}{c}\mathbf{6 j} \\
(\text { yield })^{(\mathbf{b})}\end{array}$ & $\begin{array}{c}11 \\
\left(_{(\text {yield })^{(b)}}\right.\end{array}$ \\
\hline 1 & \multirow{2}{*}{$\mathrm{Li}_{2} \mathrm{CuCl}_{4}(6 \mathrm{~mol} \%)$} & $\mathrm{rt}^{(\mathrm{b}),(\mathrm{c})}$ & $<100$ & $1: 0.1: 0.4$ & - & - \\
\hline 2 & & $40^{\circ} \mathrm{C}$ & 100 & $1: 0.1: 0.5$ & $42-50 \%$ & $8-16 \%$ \\
\hline 3 & \multirow{2}{*}{$\mathrm{CuCl}(6 \mathrm{~mol} \%)$} & $\mathrm{rt}^{(\mathrm{b})}$ & $<100$ & 1:0.1:0.4 & & - \\
\hline 4 & & $40^{\circ} \mathrm{C}$ & 100 & 1:-:0.4 & $50 \%$ & $20 \%$ \\
\hline 5 & $\begin{array}{c}\mathrm{Li}_{2} \mathrm{CuCl}_{4}(6 \text { mol \% }) \\
\text { TMEDA ( } 1 \text { equiv) }\end{array}$ & $40^{\circ} \mathrm{C}$ & $<100$ & 1:0.1:0.6 & - & - \\
\hline & $\mathrm{Li}_{2} \mathrm{CuCl}_{4}(6 \mathrm{~mol} \%)$ & & & & & \\
\hline 6 & $\begin{array}{c}\text { 1-phenyl-1-propyne (1 } \\
\text { equiv) }\end{array}$ & $40^{\circ} \mathrm{C}$ & 100 & $1: 0.1: 0.7$ & - & - \\
\hline 7 & $\begin{array}{l}\mathrm{Li}_{2} \mathrm{CuCl}_{4}(6 \mathrm{~mol} \%) \\
\text { isoprene (1 equiv) }\end{array}$ & $40{ }^{\circ} \mathrm{C}$ & $<100$ & $1: 0.1: 0.5$ & - & - \\
\hline
\end{tabular}
(a) Ratio calculated from ${ }^{1} \mathrm{H}$ NMR spectra of the crude mixtures.
(b) Isolated yields after column chromatography on silica gel.
(c) Incomplete conversion of $5 \mathrm{j}$ at $\mathrm{rt}$ and formation of a non-identified by-product, resembling $5 \mathrm{j}$, was formed
(d) Slow addition of 3 a $(0.52 \mathrm{mmol} / \mathrm{h})$ did not improve the outcome of the reaction.

Starting from the more hindered o-tolylsufonate $5 \mathrm{~s}$ did not improve the outcome of the reaction $(\mathbf{6} \mathbf{j} / \mathbf{1 1}=\mathbf{1 : 0 . 6})$.
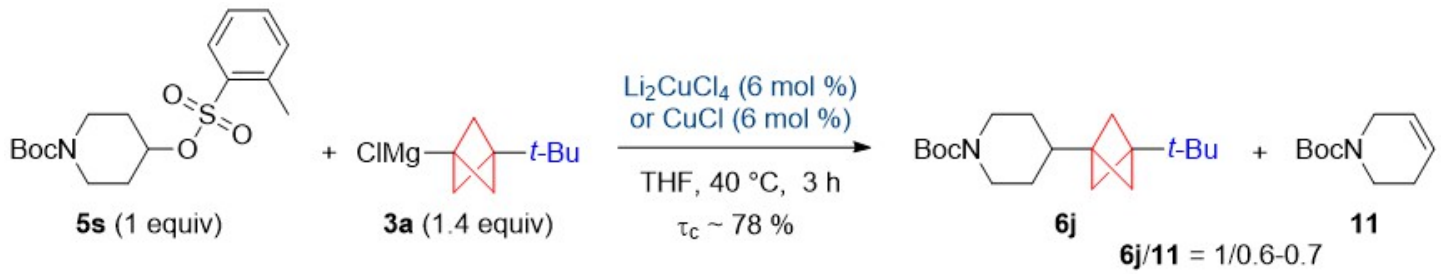

The bromide $\mathbf{5 q}$ was not reactive under the tested conditions $\left(\mathrm{Li}_{2} \mathrm{CuCl}_{4}\right.$ or $\mathrm{CuCl}, 6 \mathrm{~mol} \%$ at $0{ }^{\circ} \mathrm{C}$ or rt for $1 \mathrm{~h}$ ) as only traces of dimer $3 \mathrm{a}^{2}$ were obtained.
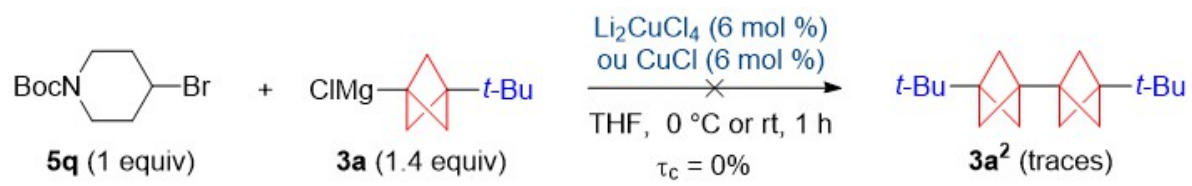

The coupling between iodide $\mathbf{5 k}$ and BCP Grignard reagent $\mathbf{3 a}$ delivered selectively the coupling product $\mathbf{6 j}$ in good yields in the presence of 3-6 mol \% of $\mathrm{Li}_{2} \mathrm{CuCl}_{4}$. Decreasing the catalytic amount of the copper salt led to the formation of a non-identified by-product in small amounts. 


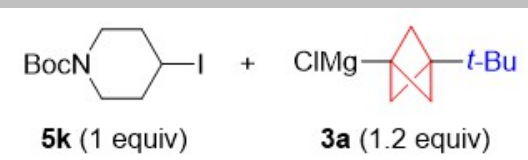

$\mathbf{5 k}$ (1 equiv)

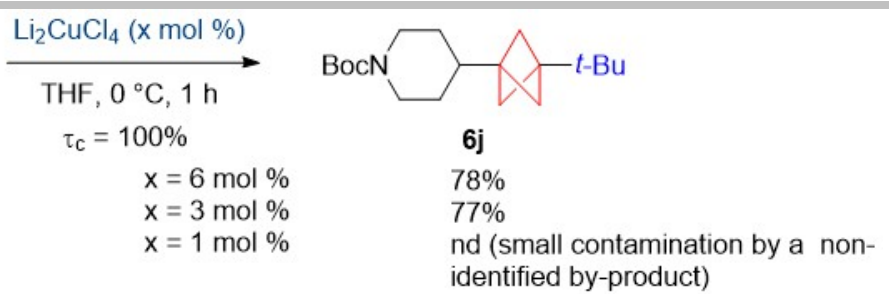

When reacted with $3 \mathbf{a}$ in the presence of a copper salt, the $\mathrm{N}$-Boc-3-iodopyrrolidine $\mathbf{5 I}$ led to a mixture of coupling product and ring-opening product $\mathbf{S 1 6}$ with a small amount of elimination product $\mathbf{S 1 8}$. $\mathrm{N}$ Tosyl-3-iodopyrrolidine $\mathbf{5 r}$ gave even a worse result as the coupling product was not formed and the ring-opened product $\mathbf{S} 17$ was the only formed product.

\begin{tabular}{|c|c|c|c|c|c|c|}
\hline & & & & Table 8 & & \\
\hline & & & {$[\mathrm{Cu}](6 \mathrm{n}$} & & & \\
\hline & & $\mathbf{3 a}$ (1.2 or 1.4 equiv) & & $\begin{array}{l}60, P \\
6 r, P\end{array}$ & $\begin{array}{l}\text { S16, } P=B o c \\
\text { s17, } P=T s\end{array}$ & $\begin{array}{l}\text { S18, } P=B o c \\
\text { S19, }=\text { Ts }\end{array}$ \\
\hline Entrée & R-I & {$[\mathrm{Cu}]$} & $\tau_{c}(\%)$ & $\begin{array}{c}\text { coupling } \\
\text { (yield) }\end{array}$ & ring opening (yield) & $\begin{array}{c}\text { elimination } \\
\text { (yield) }\end{array}$ \\
\hline 1 & 51 & $\mathrm{CuCl}$ & 100 & $60(31 \%)$ & S16 (33\%) & S18 $(2 \%)$ \\
\hline 2 & $5 r$ & $\begin{array}{l}\mathrm{CuCl} \text { or } \\
\mathrm{Li}_{2} \mathrm{CuCl}_{4}\end{array}$ & 100 & - & $\begin{array}{l}\text { S17 only product } \\
\text { observed }\end{array}$ & - \\
\hline
\end{tabular}

Starting from the tosylate $\mathbf{5 I}$, the ring-opened product was not formed. At $0{ }^{\circ} \mathrm{C}$, low conversion of $\mathbf{5 I}$ was observed. At $40{ }^{\circ} \mathrm{C}$, the coupling product 60 was obtained with a decent yield of $46 \%$ when $\mathrm{Li}_{2} \mathrm{CuCl}_{4}(6 \mathrm{~mol} \%)$ was used.

Table 9

\begin{tabular}{cccccccc} 
& \\
Entry & {$[\mathrm{Cu}]$} & $\mathrm{T}$ & $\mathrm{t}(\mathrm{h})$ & $\tau_{\mathrm{c}}(\%)$ & $\mathbf{6 0}(\mathrm{Rdt})$ & $\mathbf{S 1 6}(\mathrm{Rdt})$ & $\mathbf{S 1 8}(\mathrm{Rdt})$ \\
\hline 1 & $\mathrm{CuCl}$ & $0{ }^{\circ} \mathrm{C}$ & 3 & $<<100$ & $22 \%$ & $2 \%$ & $2 \%$ \\
2 & $\mathrm{Li}_{2} \mathrm{CuCl}_{4}$ & $40{ }^{\circ} \mathrm{C}$ & 3 & 100 & $46 \%$ & Observed & Trace
\end{tabular}

\section{II.2.2. Optimization of the cross-coupling between secondary alkyl iodides and aryl-BCP} Grignard reagents

The influence of the substituent at the $\mathrm{C} 3$ position of BCP Grignard reagents on the outcome of the cross-coupling was observed when $\mathbf{3} \mathbf{d}$ was reacted with secondary iodide $\mathbf{5 k}$. When the cross-coupling between $\mathbf{5 k}$ and $\mathbf{3 d}$ was performed using $3 \mathrm{~mol} \%$ of $\mathrm{Li}_{2} \mathrm{CuCl}_{4}$ at $\mathrm{rt}$, a long reaction time (48 h) was required to get full conversion of iodide $\mathbf{5 k}$. By using these conditions, a low yield in coupling product $6 \mathrm{~m}$ was obtained $(25 \%)$ due to the formation of homocoupling product of the BCP Grignard reagent and of the heterocoupling product between the BCP Grignard reagent $\mathbf{3 d}$ and the residual aryl Grignard reagent 4a. In addition, the dehalogenated product $\mathbf{S 2 0}$ was obtained in rather large quantities. Increasing the amount of catalyst did not impact the coupling. It is worth mentioning that 
when the reaction was performed at $0{ }^{\circ} \mathrm{C}$ or at $50{ }^{\circ} \mathrm{C}$, no improvement in the cross-coupling was noticed. Degasing the THF solution by freezing and pumping cycles did not improve the outcome of the reaction either.
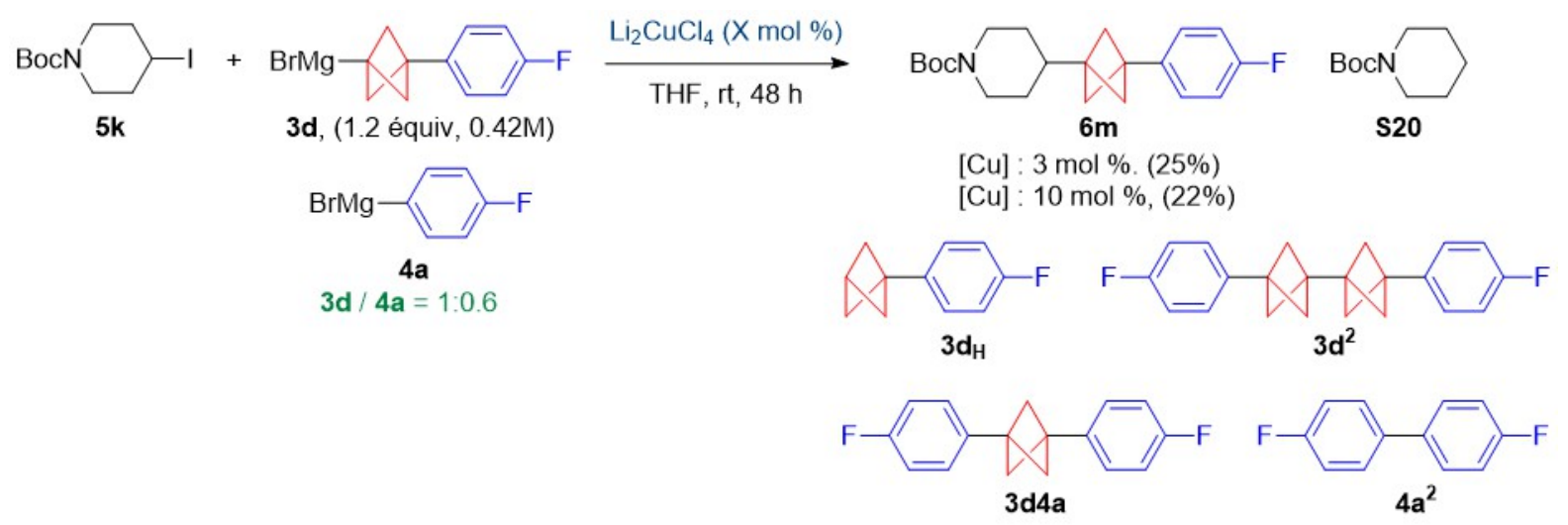

II.2.3. Scope of the cross-coupling with secondary alkyl (pseudo)halides

1-(N-Boc-piperidine)-3-(tert-butyl)bicyclo[1.1.1]pentane, $6 \mathbf{j}$

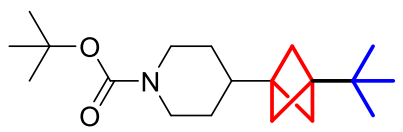

Bicyclo[1.1.1]pentane 6j was prepared according to Procedure $\mathbf{F}$ from $\mathbf{N}$-Boc-4-iodopiperidine $\mathbf{5 k}$ (47 $\mathrm{mg}, 0.15 \mathrm{mmol})$ and Grignard reagent $3 \mathrm{a}\left(0.44 \mathrm{~mL}, 0.41 \mathrm{M}\right.$ in $\left.\mathrm{Et}_{2} \mathrm{O}\right)$ for $1 \mathrm{~h}$. Purification by flash chromatography on silica gel (dry loading) (gradient of elution $\mathrm{PE} / \mathrm{Et}_{2} \mathrm{O}=95: 5$ to 90:10) yielded bicyclo[1.1.1]pentane $6 \mathbf{j}$ (36 $\mathrm{mg}, 0.12 \mathrm{mmol}, 77 \%$ ) as a white solid (mixture of rotamers).

Formula: $\mathrm{C}_{19} \mathrm{H}_{33} \mathrm{NO}_{2}$

Mass: $307.5 \mathrm{~g} \cdot \mathrm{mol}^{-1}$

mp: $94-97^{\circ} \mathrm{C}$

IR (neat): $1638,1476,1464,1441,1420,1391,1363,1336,1306,1276,1256,1236,1175,1151,1110$, 1099, 1069, 10000, 980, 930, $908 \mathrm{~cm}^{-1}$

${ }^{1} \mathrm{H}$ NMR (400 MHz, $\left.\mathrm{CDCl}_{3}\right) \delta 4.10(\mathrm{br} \mathrm{s}$ app, $2 \mathrm{H}), 2.62\left(\mathrm{brt}_{\mathrm{app}}, J=12.2 \mathrm{~Hz}, 2 \mathrm{H}\right), 1.52(\mathrm{br} \mathrm{d}$ app, $J=13.0 \mathrm{~Hz}$, $2 \mathrm{H}), 1.44(\mathrm{~s}, 9 \mathrm{H}), 1.38(\mathrm{~m}, 1 \mathrm{H}), 1.32(\mathrm{~s}, 6 \mathrm{H}), 1.03\left(\mathrm{br} \mathrm{qd}_{\mathrm{app}}, J=12.6,4.4 \mathrm{~Hz}, 2 \mathrm{H}\right), 0.80(\mathrm{~s}, 9 \mathrm{H})$

${ }^{13} \mathrm{C}$ NMR $\left(100 \mathrm{MHz}, \mathrm{CDCl}_{3}\right) \delta 155.0,79.2,46.9,44.2$ (3C), $44.0(2 \mathrm{C}), 39.6,36.8,29.5,28.54(3 \mathrm{C})$, $28.47(2 \mathrm{C}), 26.0(3 \mathrm{C})$

MS (EI) m/z: 307 (1), 251 (13), 195 (15), 194 (18), 150 (10), 133 (12), 126 (10), 107 (10), 82 (13), 57 (100), $56(22)$

HRMS (ESI) m/z: $[\mathrm{M}+\mathrm{H}]^{+}$Calcd for $\mathrm{C}_{19} \mathrm{H}_{34} \mathrm{NO}_{2} 308.2584$, Found 308.2584

1-(N-Boc-piperidine)-3-(isopropyl)bicyclo[1.1.1]pentane, 6k

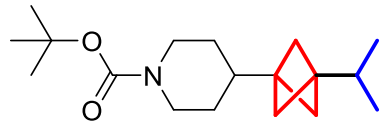

Bicyclo[1.1.1]pentane $\mathbf{6 k}$ was prepared according to Procedure $\mathbf{F}$ from $\mathbf{N}$-Boc-4-iodopiperidine $\mathbf{5 k}$ (69 $\mathrm{mg}, 0.22 \mathrm{mmol})$ and Grignard reagent $3 \mathrm{~b}\left(0.58 \mathrm{~mL}, 0.45 \mathrm{M}\right.$ in $\left.\mathrm{Et}_{2} \mathrm{O}\right)$ for $5 \mathrm{~h}$. Purification by flash chromatography on silica gel (gradient of elution $\mathrm{PE} / \mathrm{Et}_{2} \mathrm{O}=95: 5$ to $90: 10$ ) yielded bicyclo[1.1.1]pentane $6 \mathbf{k}(48 \mathrm{mg}, 0.16 \mathrm{mmol}, 75 \%)$ as a colourless oil (mixture of rotamers).

Formula: $\mathrm{C}_{18} \mathrm{H}_{31} \mathrm{NO}_{2}$

Mass: $293.5 \mathrm{~g} \cdot \mathrm{mol}^{-1}$ 
IR (neat): 1693, 1466, 1446, 1419, 1391, 1364, 1317, 1283, 1265, 1253, 1234, 1175, 1160, 1143, 1110, 1099, 1059, 1007, 981, $937 \mathrm{~cm}^{-1}$

${ }^{1} \mathrm{H}$ NMR $\left(400 \mathrm{MHz}, \mathrm{CDCl}_{3}\right) \delta 4.10\left(\mathrm{br} \mathrm{s}_{\mathrm{app}}, 2 \mathrm{H}\right), 2.62\left(\mathrm{br} \mathrm{t}_{\mathrm{app}}, \mathrm{J}=12.1 \mathrm{~Hz}, 2 \mathrm{H}\right), 1.62(\mathrm{~m}, 1 \mathrm{H}), 1.53(\mathrm{br}$ $\left.\mathrm{d}_{\mathrm{app}}, \mathrm{J}=12.8 \mathrm{~Hz}, 2 \mathrm{H}\right), 1.45(\mathrm{~s}, 9 \mathrm{H}), 1.44(\mathrm{~m}, 1 \mathrm{H}), 1.32(\mathrm{~s}, 6 \mathrm{H}), 1.04$ (ddd, $J=24.5,12.4,4.2 \mathrm{~Hz}, 2 \mathrm{H}$ ), $0.79(\mathrm{~d}, J=6.8 \mathrm{~Hz}, 6 \mathrm{H})$

${ }^{13} \mathrm{C}$ NMR $\left(100 \mathrm{MHz}, \mathrm{CDCl}_{3}\right) \delta 155.0,79.2,45.3(3 \mathrm{C}), 44.0(2 \mathrm{C}), 43.6,41.2,36.8,28.6,28.64(3 \mathrm{C})$, $28.56(2 \mathrm{C}), 18.9(2 \mathrm{C})$

MS (EI) m/z: 237 (11), 194 (16), 178 (6), $166(6), 152$ (8), 133 (10), 126 (9), $122(10), 107$ (14), 82 (17), 80 (7), 67 (7), 57 (100), 56 (56), 55 (16)

HRMS (ESI) m/z: [M+Na] $]^{+}$Calcd for $\mathrm{C}_{18} \mathrm{H}_{31} \mathrm{NO}_{2} \mathrm{Na} 316.2247$, Found 316.2247

1-(N-Boc-piperidine)-3-(cyclopentyl)bicyclo[1.1.1]pentane, $6 \mathbf{I}$

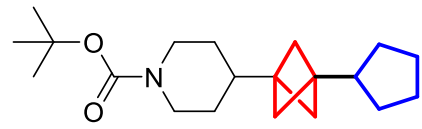

Bicyclo[1.1.1]pentane 6I was prepared according to Procedure $\mathbf{F}$ from $\mathrm{N}$-Boc-4-iodopiperidine (5k) (69 $\mathrm{mg}, 0.22 \mathrm{mmol})$ and Grignard reagent $3 \mathrm{c}\left(0.58 \mathrm{~mL}, 0.46 \mathrm{M}\right.$ in $\left.\mathrm{Et}_{2} \mathrm{O}\right)$ for $5 \mathrm{~h}$. Purification by flash chromatography on silica gel (gradient of elution $\mathrm{PE} / \mathrm{Et}_{2} \mathrm{O}=95: 5$ to $90: 10$ ) yielded bicyclo[1.1.1]pentane $6 \mathbf{I}(49 \mathrm{mg}, 0.15 \mathrm{mmol}, 69 \%)$ as a colourless oil (mixture of rotamers).

Formula: $\mathrm{C}_{20} \mathrm{H}_{33} \mathrm{NO}_{2}$

Mass: $319.5 \mathrm{~g} \cdot \mathrm{mol}^{-1}$

IR (neat): 1693, 1478, 1465, 1446, 1419, 1364, 1324, 1302, 1265, 1253, 1233, 1172, 1147, 1095, 1012 , 982, $936 \mathrm{~cm}^{-1}$

${ }^{1} \mathrm{H}$ NMR $\left(400 \mathrm{MHz}, \mathrm{CDCl}_{3}\right) \delta 4.10$ (br sapp, 2H), 2.62 (brt tapp, $\left.J=12.1 \mathrm{~Hz}, 2 \mathrm{H}\right), 1.89(\mathrm{~m}, 1 \mathrm{H}), 1.63-1.47$ $(\mathrm{m}, 8 \mathrm{H}), 1.44(\mathrm{~s}, 9 \mathrm{H}), 1.45(\mathrm{~m}, 1 \mathrm{H}), 1.34(\mathrm{~s}, 6 \mathrm{H}), 1.27-1.13(\mathrm{~m}, 2 \mathrm{H}), 1.04(\mathrm{ddd}, J=16.8,11.9,3.6 \mathrm{~Hz}$, $2 \mathrm{H})$

${ }^{13} \mathrm{C}$ NMR $\left(100 \mathrm{MHz}, \mathrm{CDCl}_{3}\right) \delta 155.0,79.2,46.3(3 \mathrm{C}), 43.9(2 \mathrm{C}), 42.3,41.6,40.5,36.9,29.1(2 \mathrm{C}), 28.6$ (3C), $28.5(2 \mathrm{C}), 25.8(2 \mathrm{C})$

MS (EI) m/z: 263 (9), 194 (14), 166 (8), 153 (10), 126 (15), 122 (12), 108 (10), 107 (11), 95 (8), 93 (8), 82 (22), 80 (9), 67 (10), 57 (100), 56 (69), 55 (21).

HRMS (ESI) m/z: $[\mathrm{M}+\mathrm{H}]^{+}$Calcd for $\mathrm{C}_{20} \mathrm{H}_{34} \mathrm{NO}_{2} 320.2584$, Found 320.2584

3-(p-Fluorophenyl)-1-(N-Boc-piperidine)bicyclo[1.1.1]pentane, 6m

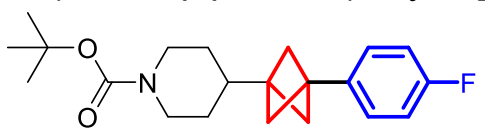

Bicyclo[1.1.1]pentane $6 \mathbf{m}$ was prepared according to Procedure $\mathbf{F}$ (at rt instead of $0{ }^{\circ} \mathrm{C}$ ) from $\mathrm{N}$-Boc-4-

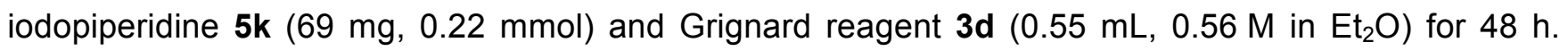
Purification by flash chromatography on silica gel (gradient of elution $\mathrm{PE} / \mathrm{Et}_{2} \mathrm{O}=95: 5$ to $90: 10$ ) produced bicyclo[1.1.1]pentane $6 \mathrm{~m}(18 \mathrm{mg}, 0.055 \mathrm{mmol}, 25 \%)$ as a colourless oil (mixture of rotamers).

Formula: $\mathrm{C}_{21} \mathrm{H}_{28} \mathrm{FNO}_{2}$

Mass: $345.5 \mathrm{~g} \cdot \mathrm{mol}^{-1}$

IR (neat): 1687, 1602, 1519, 1504, 1478, 1465, 1446, 1420, 1391, 1364, 1306, 1273, 1254, 1233, 1220 , $1174,1153,1109,1097,1030,1005,967,938,904 \mathrm{~cm}^{-1}$

${ }^{1} \mathrm{H}$ NMR $\left(400 \mathrm{MHz}, \mathrm{CDCl}_{3}\right) \delta 7.15\left(\mathrm{dd}_{\mathrm{app}}, J=8.7,5.5 \mathrm{~Hz}, 2 \mathrm{H}\right), 6.96\left(\mathrm{t}_{\mathrm{app}}, J=8.8 \mathrm{~Hz}, 2 \mathrm{H}\right), 4.15\left(\mathrm{br} \mathrm{s}_{\mathrm{app}}\right.$, 2H), $2.66(\mathrm{br} \mathrm{t}, J=12.1 \mathrm{~Hz}, 2 \mathrm{H}), 1.83(\mathrm{~s}, 6 \mathrm{H}), 1.60\left(\mathrm{br} \mathrm{d} \mathrm{app}_{1}, J=13.5 \mathrm{~Hz}, 2 \mathrm{H}\right), 1.52\left(\mathrm{br} \mathrm{dt}_{\mathrm{app}}, J=11.8\right.$, 3.7 Hz, 1H), $1.46(\mathrm{~s}, 9 \mathrm{H}), 1.12\left(\mathrm{qd}_{\mathrm{app}}, J=12.6,4.4 \mathrm{~Hz}, 2 \mathrm{H}\right)$

${ }^{13} \mathrm{C}$ NMR $\left(100 \mathrm{MHz}, \mathrm{CDCl}_{3}\right) \delta 161.7(\mathrm{~d}, \mathrm{~J}=244.2 \mathrm{~Hz}), 155.0,137.2(\mathrm{~d}, J=3.0 \mathrm{~Hz}), 127.6(\mathrm{~d}, \mathrm{~J}=7.9 \mathrm{~Hz}$, 2C), 114.9 (d, $J=21.3 \mathrm{~Hz}, 2 \mathrm{C}), 79.3,50.1(3 \mathrm{C}), 43.9(2 \mathrm{C}), 41.7,40.4,36.5,28.54(3 \mathrm{C}), 28.47(2 \mathrm{C})$ 
${ }^{19}$ F NMR $\left(400 \mathrm{MHz}, \mathrm{CDCl}_{3}\right) \delta-116.73$

MS (EI) m/z: 289 (5), 166 (19), 161 (10), 129 (5), 126 (6), 123 (22), 122 (22), 109 (7), 82 (13), 57 (100), $56(61), 55(16)$

HRMS (ESI) m/z: $[\mathrm{M}+\mathrm{H}]^{+}$Calcd for $\mathrm{C}_{21} \mathrm{H}_{29} \mathrm{FNO}_{2} 346.2177$, Found 346.2178

1-(tert-Butyl)-3-(N-Boc azetidine)bicyclo[1.1.1]pentane, $6 \mathbf{n}$

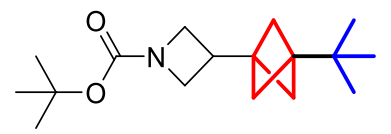

Bicyclo[1.1.1]pentane $\mathbf{6 n}$ was prepared according to Procedure $\mathbf{F}$ from $\mathbf{N}$-Boc-3-iodoazetidine $\mathbf{5 n}$ (62 $\mathrm{mg}, 0.22 \mathrm{mmol})$ and Grignard reagent $3 \mathrm{a}\left(0.63 \mathrm{~mL}, 0.42 \mathrm{M}\right.$ in $\left.\mathrm{Et}_{2} \mathrm{O}\right)$ for $1 \mathrm{~h}$. Purification by flash chromatography on silica gel (gradient of elution $\mathrm{PE} / \mathrm{Et}_{2} \mathrm{O}=97: 3$ to $95: 5$ ) led to bicyclo[1.1.1]pentane 6n (35 mg, $0.13 \mathrm{mmol}, 57 \%)$ as a beige solid.

Formula: $\mathrm{C}_{17} \mathrm{H}_{29} \mathrm{NO}_{2}$

Mass: $279.4 \mathrm{~g} \cdot \mathrm{mol}^{-1}$

mp: $67-70^{\circ} \mathrm{C}$

IR (neat): $1703,1478,1459,1396,1360,1298,1267,1255,1225,1198,1165,1127,947,912 \mathrm{~cm}^{-1}$

${ }^{1} \mathrm{H}$ NMR $\left(400 \mathrm{MHz}, \mathrm{CDCl}_{3}\right) \delta 3.87\left(\mathrm{t}_{\mathrm{app}}, J=8.4 \mathrm{~Hz}, 2 \mathrm{H}\right), 3.59(\mathrm{dd}, J=8.5,5.4 \mathrm{~Hz}, 2 \mathrm{H}), 2.55\left(\mathrm{tt}_{\mathrm{app}}\right.$, $J=8.3,5.4 \mathrm{~Hz}, 1 \mathrm{H}), 1.43(\mathrm{~s}, 6 \mathrm{H}), 1.42(\mathrm{~s}, 9 \mathrm{H}), 0.83(\mathrm{~s}, 9 \mathrm{H})$

${ }^{13} \mathrm{C}$ NMR $\left(100 \mathrm{MHz}, \mathrm{CDCl}_{3}\right) \delta 156.6,79.2,51.4(2 \mathrm{C}), 48.1,44.3$ (3C), 37.5, 29.6, 29.5, 28.5 (3C), 25.9 $(3 \mathrm{C})$

MS (EI) m/z: 279 (1), 223 (5), 135 (5), 107 (6), 94 (9), 93 (13), 82 (12), 79 (7), 58 (5), 57 (100), 55 (7)

HRMS (ESI) m/z: [M+Na] ${ }^{+}$Calcd for $\mathrm{C}_{17} \mathrm{H}_{29} \mathrm{NO}_{2} \mathrm{Na} 302.2091$, Found 302.2092

1-(tert-Butyl)-3-(N-Boc pyrrolidine)bicyclo[1.1.1]pentane, 60

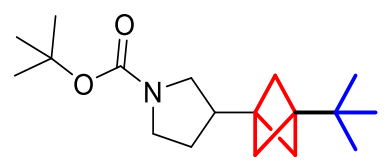

Bicyclo[1.1.1]pentane $\mathbf{6 o}$ was prepared according to Procedure $\mathbf{G}$ from $\mathrm{N}$-Boc-3-(tosyloxy)pyrrolidine $5 \mathrm{~m}(51 \mathrm{mg}, 0.15 \mathrm{mmol})$ and Grignard reagent $3 \mathrm{a}\left(0.51 \mathrm{~mL}, 0.41 \mathrm{M}^{\mathrm{in}} \mathrm{Et}_{2} \mathrm{O}\right)$ for $3.5 \mathrm{~h}$. Purification by flash chromatography on silica gel (gradient of elution $\mathrm{PE} / \mathrm{Et}_{2} \mathrm{O}=95: 5$ to $90: 10$ ) led to bicyclo[1.1.1]pentane $60(20 \mathrm{mg}, 0.070 \mathrm{mmol}, 46 \%)$ as a yellowish oil.

Formula: $\mathrm{C}_{18} \mathrm{H}_{31} \mathrm{NO}_{2}$

Mass: $293.5 \mathrm{~g} \cdot \mathrm{mol}^{-1}$

IR (neat): 1698, 1478, 1457, 1401, 1364, 1342, 1302, 1254, 1169, 1141, 1114, 1077, 976, 921, 878, $772,733,646 \mathrm{~cm}^{-1}$

${ }^{1} \mathrm{H}$ NMR $\left(400 \mathrm{MHz}, \mathrm{CDCl}_{3}\right) \delta 3.40(\mathrm{~m}, 1 \mathrm{H}), 3.34\left(\mathrm{dd}, \mathrm{J}_{\mathrm{AB}}=10.7,7.6 \mathrm{~Hz}, 1 \mathrm{H}\right), 3.24(\mathrm{~m}, 1 \mathrm{H}), 3.00(\mathrm{dd}$, $\left.J_{\mathrm{AB}}=10.6,7.7 \mathrm{~Hz}, 1 \mathrm{H}\right), 2.20$ (quint $\left._{\mathrm{app}}, J=7.5 \mathrm{~Hz}, 1 \mathrm{H}\right), 1.81(\mathrm{~m}, 1 \mathrm{H}), 1.58(\mathrm{~m}, 1 \mathrm{H}), 1.45(\mathrm{~s}, 9 \mathrm{H}), 1.39(\mathrm{~d}$, $J=1.1 \mathrm{~Hz}, 6 \mathrm{H}), 0.81(\mathrm{~s}, 9 \mathrm{H})$

${ }^{13} \mathrm{C}$ NMR $\left(100 \mathrm{MHz}, \mathrm{CDCl}_{3}\right) \delta 154.7,79.0,48.5,47.5,45.8,45.1$ (3C), 39.4, 37.4, 29.5, 28.6 (3C), 28.5, $26.0(3 \mathrm{C})$

MS (EI) m/z: 293 (1), 237 (14), 222 (15), 178 (9), 153 (10), 136 (9), 119 (6), 109 (9), 57 (100), 55 (7)

HRMS (ESI) $\mathrm{m} / \mathrm{z}$ : $[\mathrm{M}+\mathrm{Na}]^{+}$Calcd for $\mathrm{C}_{18} \mathrm{H}_{31} \mathrm{NO}_{2} \mathrm{Na} 316.2247$, Found 316.2247 


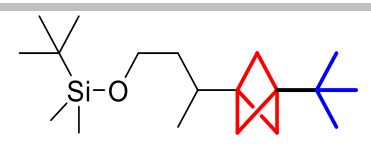

Bicyclo[1.1.1]pentane $\mathbf{6 p}$ was prepared according to Procedure $\mathbf{F}$ from 2-iodo-4-(tertbutyldimethylsilyloxy)butane 50 (69 $\mathrm{mg}, 0.22 \mathrm{mmol})$ and Grignard reagent $3 \mathrm{a}\left(0.59 \mathrm{~mL}, 0.45 \mathrm{M} \mathrm{in} \mathrm{Et}_{2} \mathrm{O}\right)$ for $6 \mathrm{~h}$. Purification by flash chromatography on silica gel $\left(\mathrm{PE} / \mathrm{Et}_{2} \mathrm{O}\right.$ up to 98:2) yielded

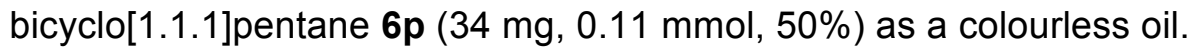

Formula: $\mathrm{C}_{19} \mathrm{H}_{38} \mathrm{OSi}$

Mass: $310.6 \mathrm{~g} \cdot \mathrm{mol}^{-1}$

IR (neat): 1472, 1461, 1389, 1361, 1273, 1255, 1225, 1196, 1096, 1032, 1005, 987, $939 \mathrm{~cm}^{-1}$

${ }^{1} \mathrm{H}$ NMR $\left(400 \mathrm{MHz}, \mathrm{CDCl}_{3}\right) \delta 3.72-3.54(\mathrm{~m}, 2 \mathrm{H}), 1.70-1.50(\mathrm{~m}, 2 \mathrm{H}), 1.33(\mathrm{~s}, 6 \mathrm{H}), 1.16(\mathrm{~m}, 1 \mathrm{H}), 0.89$ (s, 9H), $0.82(\mathrm{~s}, 9 \mathrm{H}), 0.79(\mathrm{~d}, J=6.8 \mathrm{~Hz}, 3 \mathrm{H}), 0.05(\mathrm{~s}, 6 \mathrm{H})$

${ }^{13} \mathrm{C}$ NMR $\left(100 \mathrm{MHz}, \mathrm{CDCl}_{3}\right) \delta 62.0,46.7,44.3$ (3C), 41.0, 36.7, 30.3, 29.5, 26.1 (3C), 26.0 (3C), 18.5, $16.3,-5.1,-5.2$

MS (EI) m/z: 295 (1), 169 (12), 121 (13), 101 (27), 95 (10), 83 (16), 75 (100), 73 (19), 59 (10), 57 (25), $55(12)$

HRMS (ESI) m/z: $[\mathrm{M}+\mathrm{H}]^{+}$Calcd for $\mathrm{C}_{19} \mathrm{H}_{39} \mathrm{OSi} 311.2765$, Found 311.2764

1-tert-Butyl-3-[ N-tosyl, N-Boc, N-3s-butyl]bicyclo[1.1.1]pentane, 6q

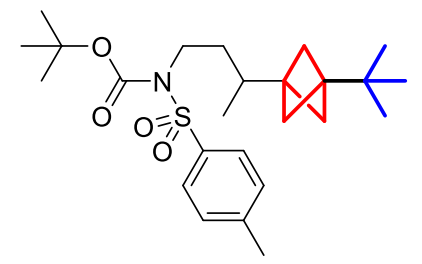

Bicyclo[1.1.1]pentane $\mathbf{6 q}$ was prepared according to Procedure $\mathbf{F}$ from $\mathrm{N}$-Boc, $\mathrm{N}$-tosyl-3iodobutylamine $5 \mathrm{p}(100 \mathrm{mg}, 0.22 \mathrm{mmol})$ and Grignard reagent $3 \mathrm{a}\left(0.59 \mathrm{~mL}, 0.45 \mathrm{M}^{\text {in }} \mathrm{Et}_{2} \mathrm{O}\right)$ for $6 \mathrm{~h}$. Purification by flash chromatography on silica gel (gradient of elution $\mathrm{PE} / \mathrm{Et}_{2} \mathrm{O}=95: 5$ to $90: 10$ ) led to bicyclo[1.1.1]pentane $6 \mathbf{q}(53 \mathrm{mg}, 0.12 \mathrm{mmol}, 53 \%)$ as a white solid.

Formula: $\mathrm{C}_{25} \mathrm{H}_{39} \mathrm{NO}_{4} \mathrm{~S}$

Mass: $449.7 \mathrm{~g} \cdot \mathrm{mol}^{-1}$

mp: $77-83^{\circ} \mathrm{C}$

IR (neat): 1726, 1599, 1459, 1358, 1287, 1258, 1226, 1196, 1153, 1089, 1044, 1019, 957, $937 \mathrm{~cm}^{-1}$

${ }^{1} \mathrm{H}$ NMR $\left(400 \mathrm{MHz}, \mathrm{CDCl}_{3}\right) \delta 7.77(\mathrm{~d}, J=8.4 \mathrm{~Hz}, 2 \mathrm{H}), 7.30(\mathrm{~d}, \mathrm{~J}=8.0 \mathrm{~Hz}, 2 \mathrm{H}), 3.82\left(\mathrm{t}_{\mathrm{app}}, \mathrm{J}=8.0 \mathrm{~Hz}\right.$, 2H), $2.43(\mathrm{~s}, 3 \mathrm{H}), 1.80(\mathrm{~m}, 1 \mathrm{H}), 1.55(\mathrm{~m}, 1 \mathrm{H}), 1.44(\mathrm{~m}, 1 \mathrm{H}), 1.38(\mathrm{~s}, 6 \mathrm{H}), 1.33(\mathrm{~s}, 9 \mathrm{H}), 0.88(\mathrm{~d}, J=6.8$ $\mathrm{Hz}, 3 \mathrm{H}), 0.82(\mathrm{~s}, 9 \mathrm{H})$

${ }^{13} \mathrm{C}$ NMR $\left(100 \mathrm{MHz}, \mathrm{CDCl}_{3}\right) \delta 151.0,144.0,137.7,129.3(2 \mathrm{C}), 127.9(2 \mathrm{C}), 84.0,46.7,46.2,44.4(3 \mathrm{C})$, 40.7, 34.2, 31.9, 29.5, $28.0(3 \mathrm{C}), 26.0(3 \mathrm{C}), 21.7,16.2$

MS (EI) m/z: 334 (1), 194 (47), 184 (28), 155 (70), 137 (19), 123 (21), 121 (33), 110 (38), 109 (43), 107 (15), 96 (14), 95 (32), 94 (17), 93 (22), 92 (11), 91 (100), 83 (16), 81 (19), 79 (16), 69 (10), 67 (16), 65 (18), 57 (46), 55 (30)

HRMS (ESI) $\mathrm{m} / \mathrm{z}$ : $[\mathrm{M}+\mathrm{Na}]^{+}$Calcd for $\mathrm{C}_{25} \mathrm{H}_{39} \mathrm{NO}_{4} \mathrm{SNa} 472.2492$, Found 472.2506

\section{II.3. Mechanistic studies}


In order to investigate the mechanism oft he reaction, the coupling between Grignard reagent 3a and radical clock $\mathrm{S}^{20}{ }^{29}$ was attempted under the optimized conditions. Unfortunately, a mixture of products was obtained preventing us to draw any conclusion about the formation of radical intermediates.

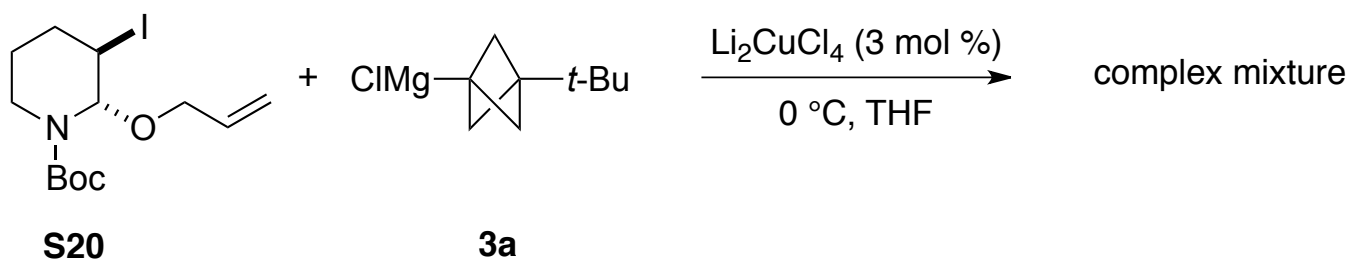

${ }^{29}$ For the preparation, see: Gonnard, L.; Guérinot, A.; Cossy, J. Chem. Eur. J. 2015, 21, 12797. 
( $\left.{ }^{1} \mathrm{HNMR}, 400 \mathrm{MHz}, \mathrm{CDCl}\right)$ 


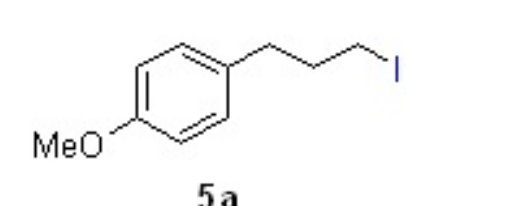

$\left({ }^{13} \mathrm{CNMR}, 100 \mathrm{MHz}, \mathrm{CDCl}\right)$ 


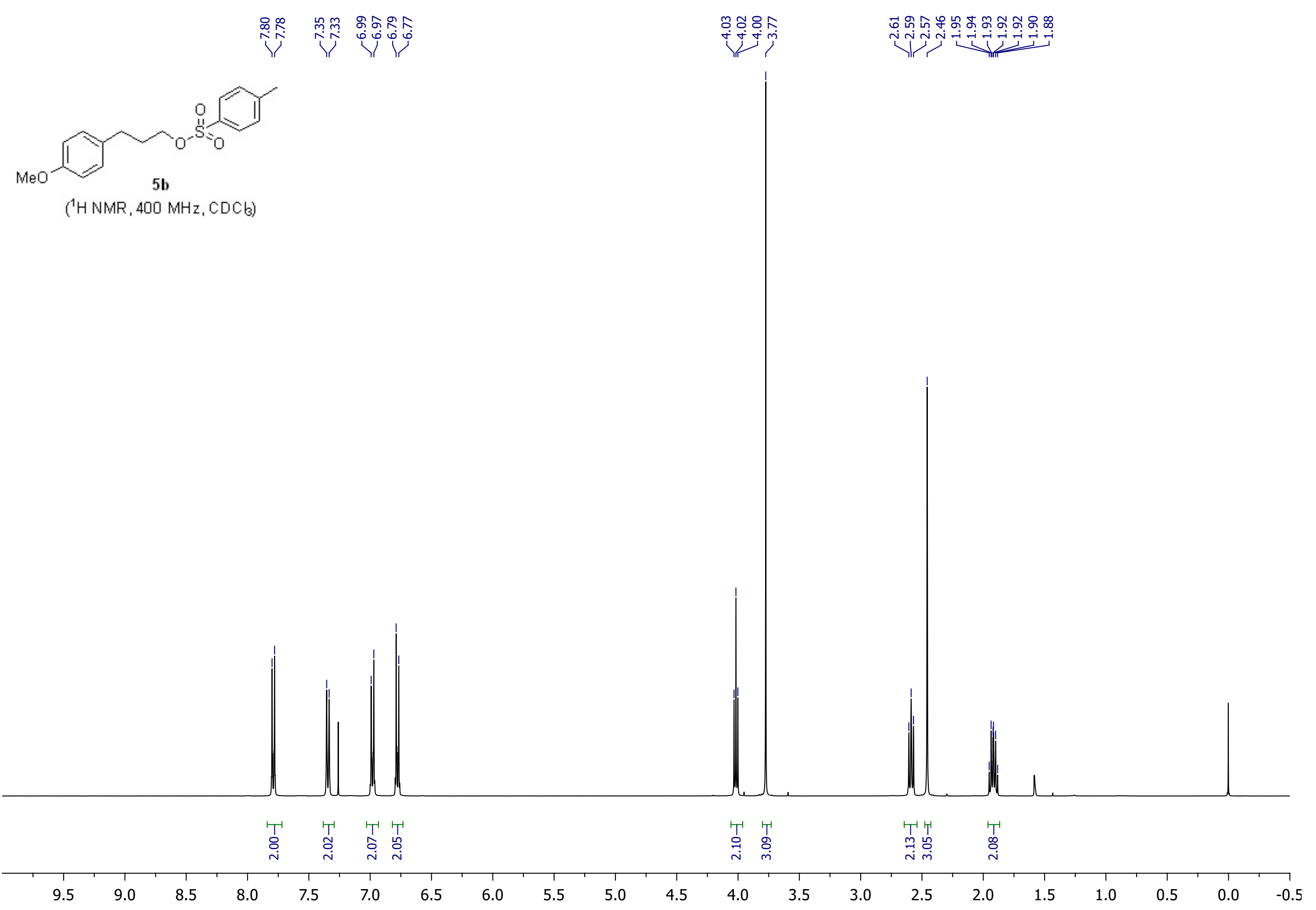



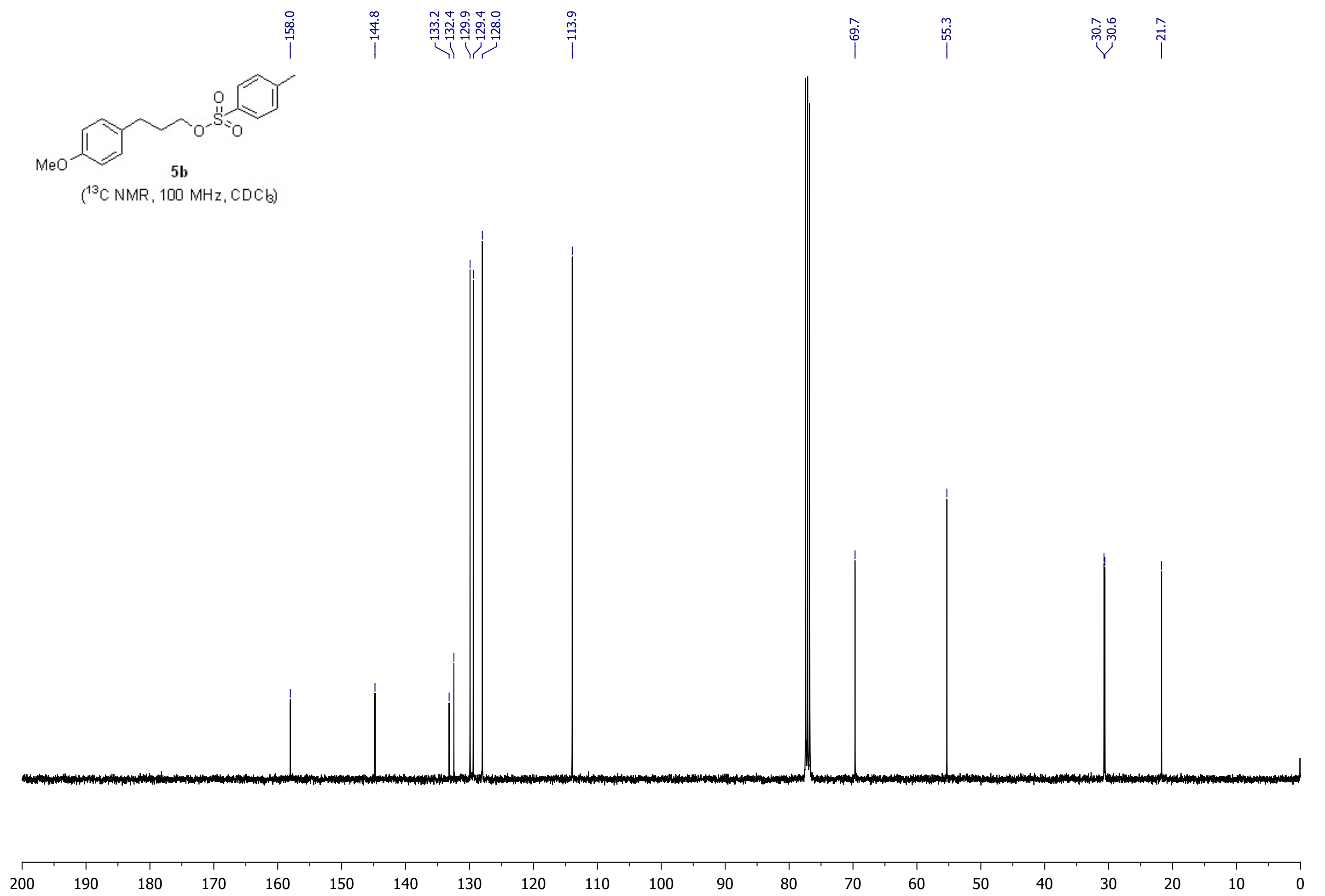


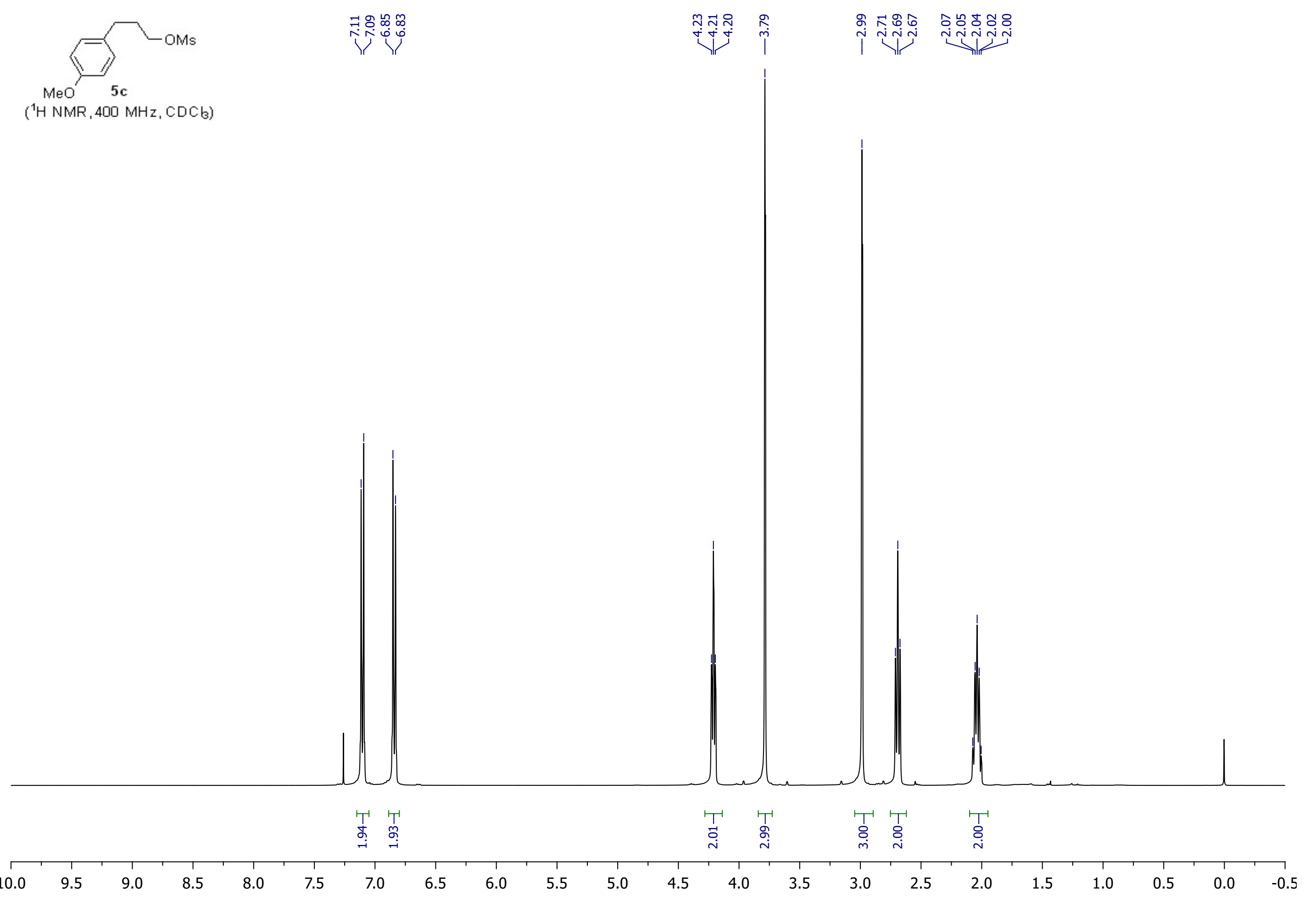




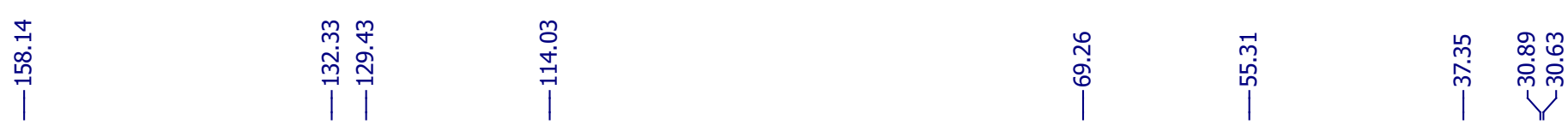

$\mathrm{MeO} 5 \mathrm{c}$

$\left({ }^{13} \mathrm{CNMR}, 100 \mathrm{MHz}, \mathrm{CDCl}_{3}\right)$ 


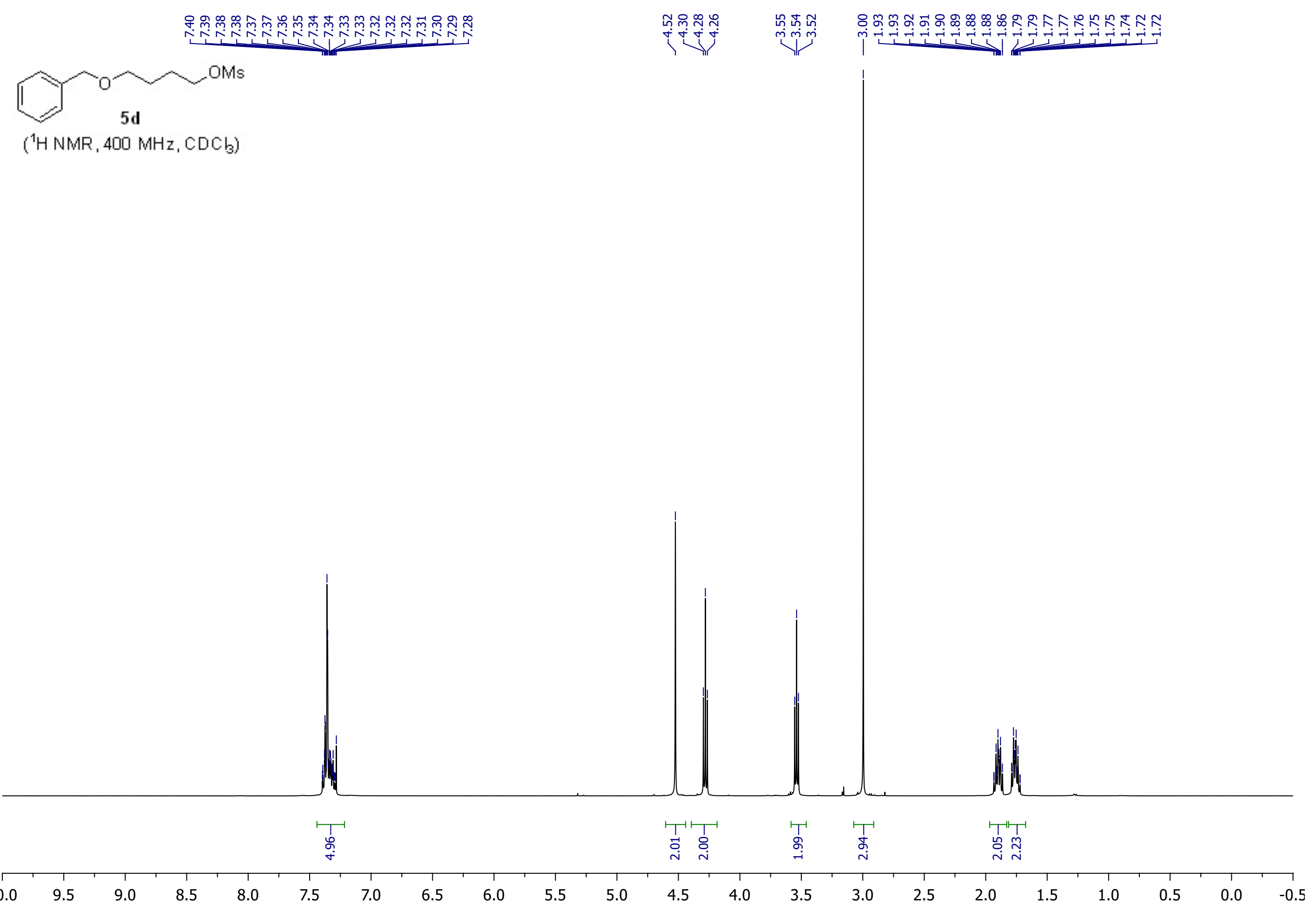




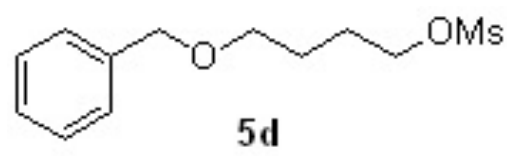

$\left({ }^{13} \mathrm{C} N \mathrm{MR}, 100 \mathrm{MHz}, \mathrm{CDCl}_{3}\right)$

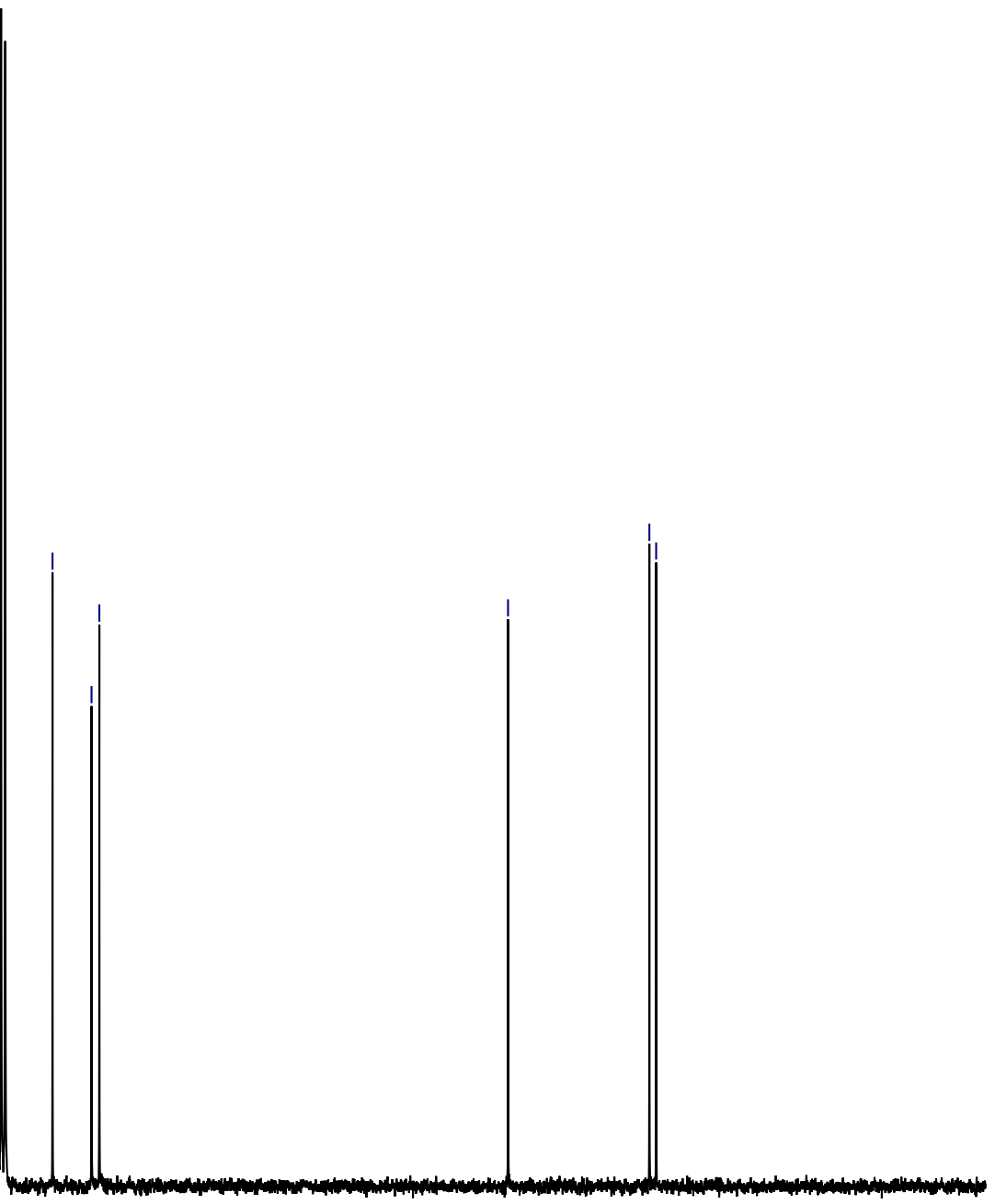




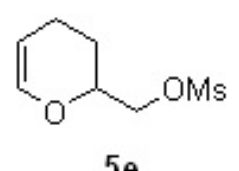

$5 \mathrm{e}$

$\left({ }^{1} \mathrm{HNMR}, 400 \mathrm{MHz}, \mathrm{CDC}_{3}\right)$
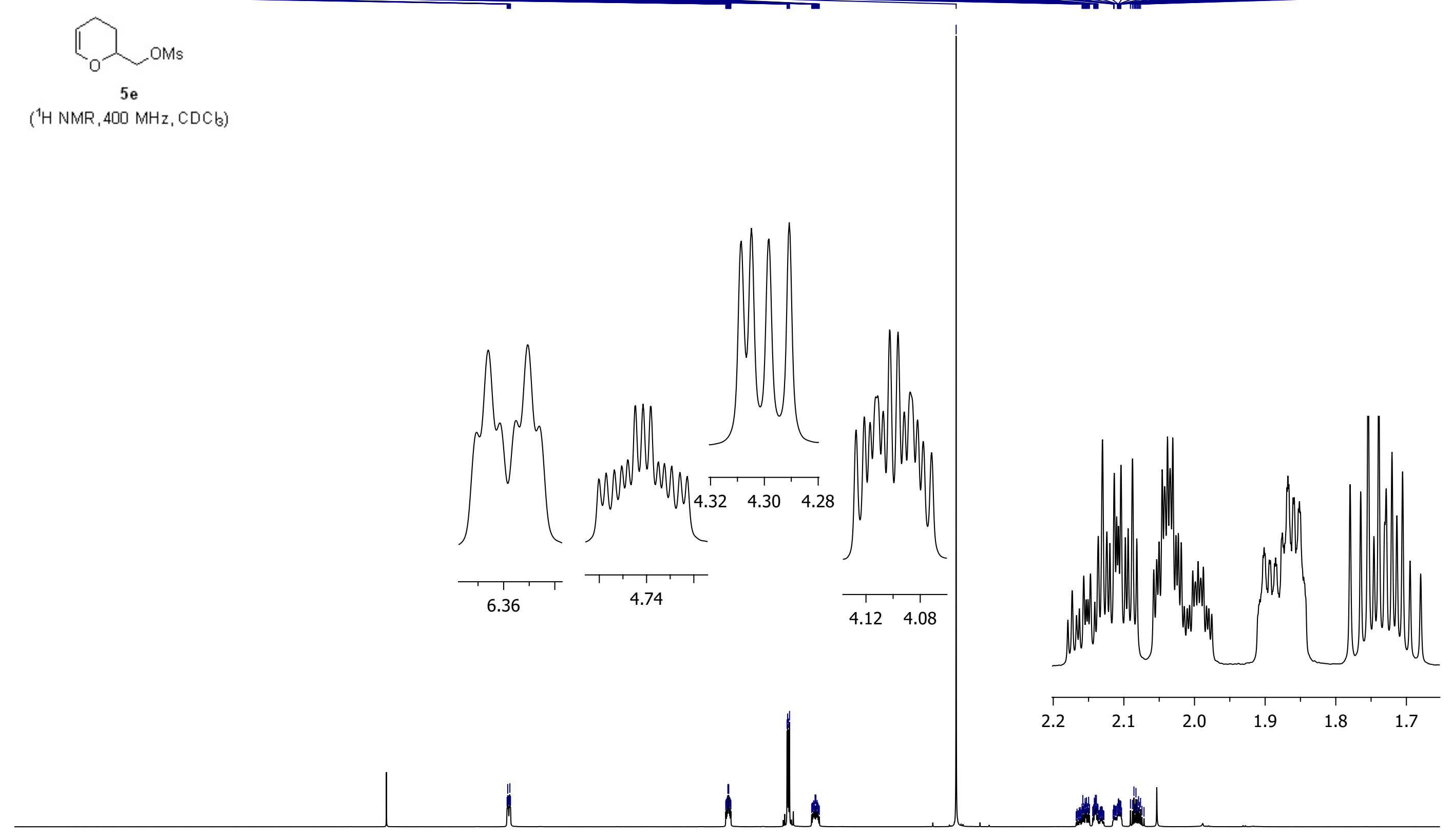

Wh

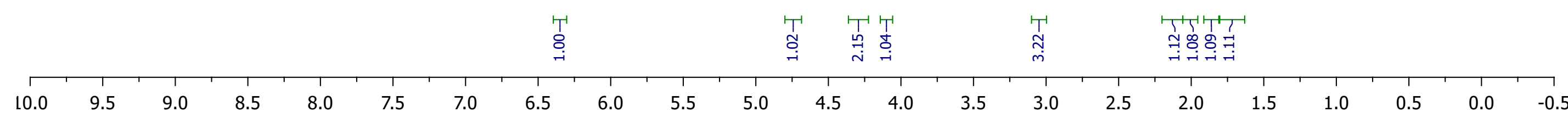




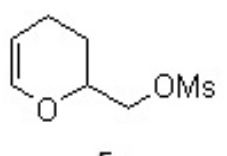

$\left({ }^{13} \mathrm{CNMR}, 100 \mathrm{MHz}, \mathrm{CDCl}_{3}\right)$

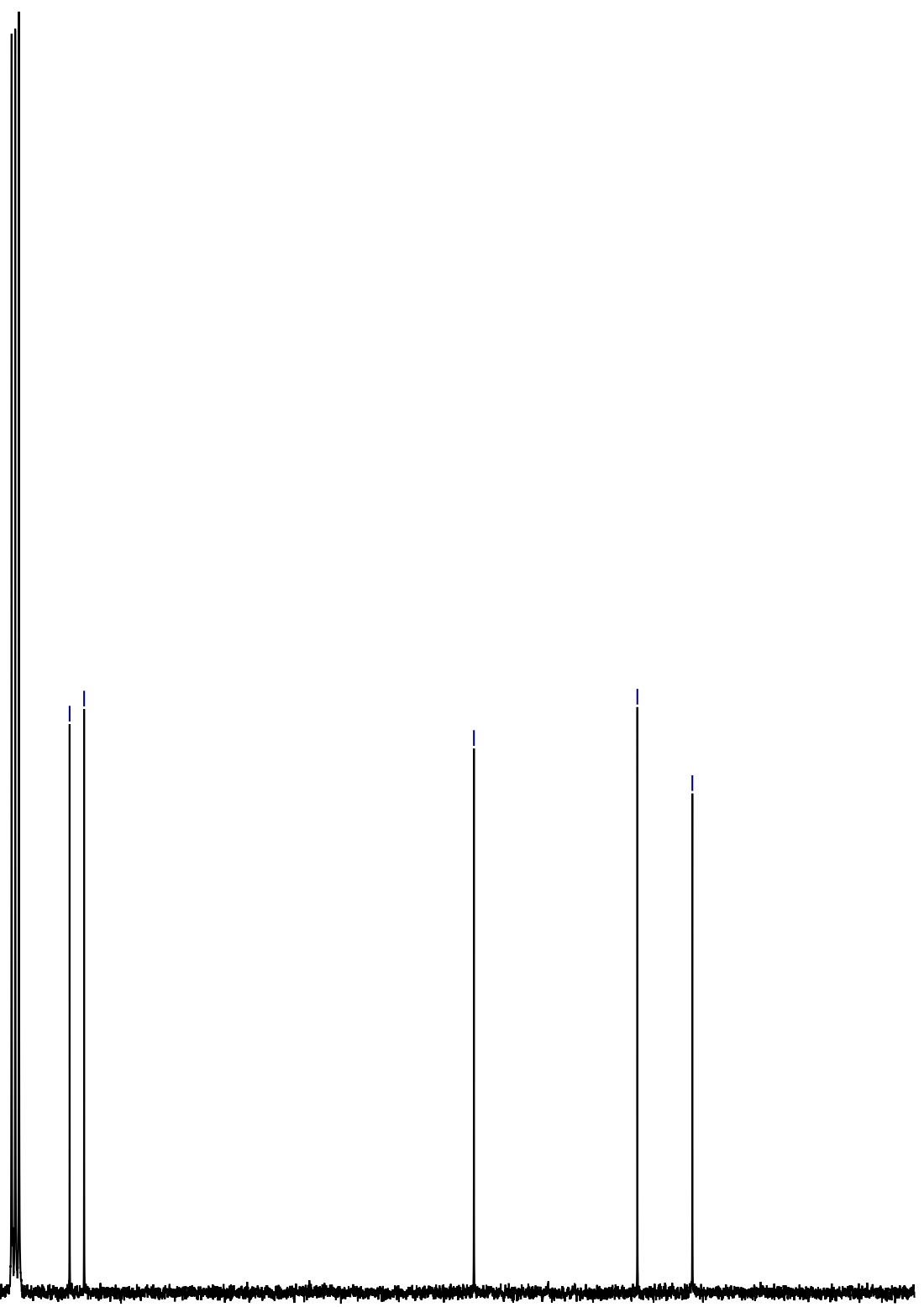




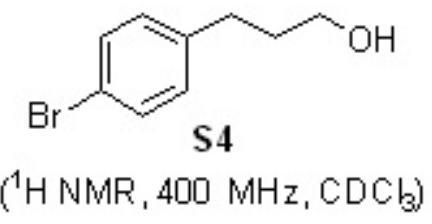

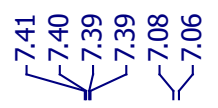

$\underbrace{i}$

$\underbrace{\infty} \overbrace{}^{\circ} \stackrel{\leftrightarrow}{\circ}$

我

$$
\text { ( } \left.{ }^{1} \mathrm{HNMR}, 400 \mathrm{MHz}, \mathrm{CDCl}_{3}\right)
$$
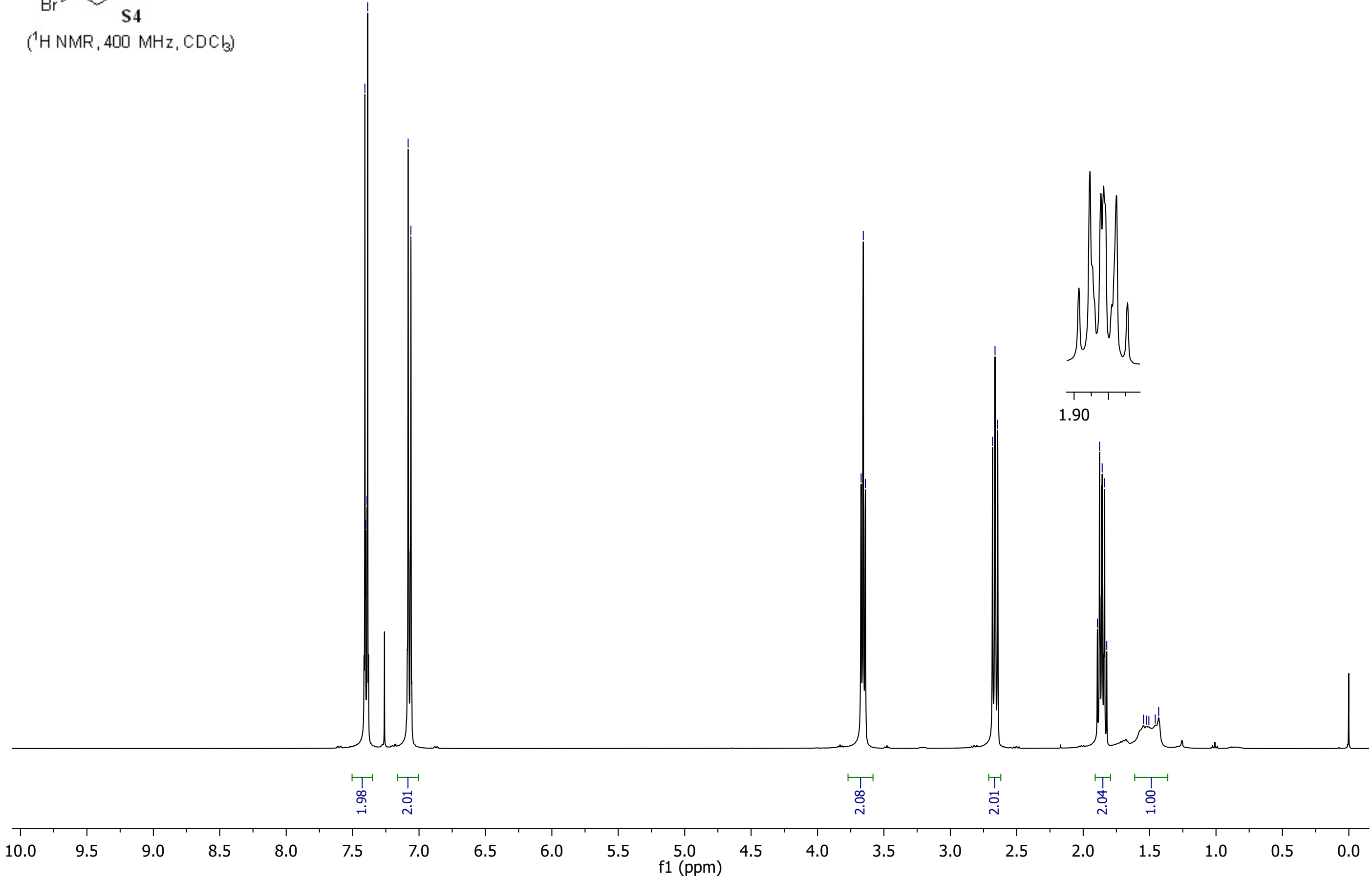
$\left({ }^{13} \mathrm{CNMR}, 100 \mathrm{MHz}, \mathrm{CDCl}_{3}\right)$<smiles>OCCCc1ccc(Br)cc1</smiles>

|

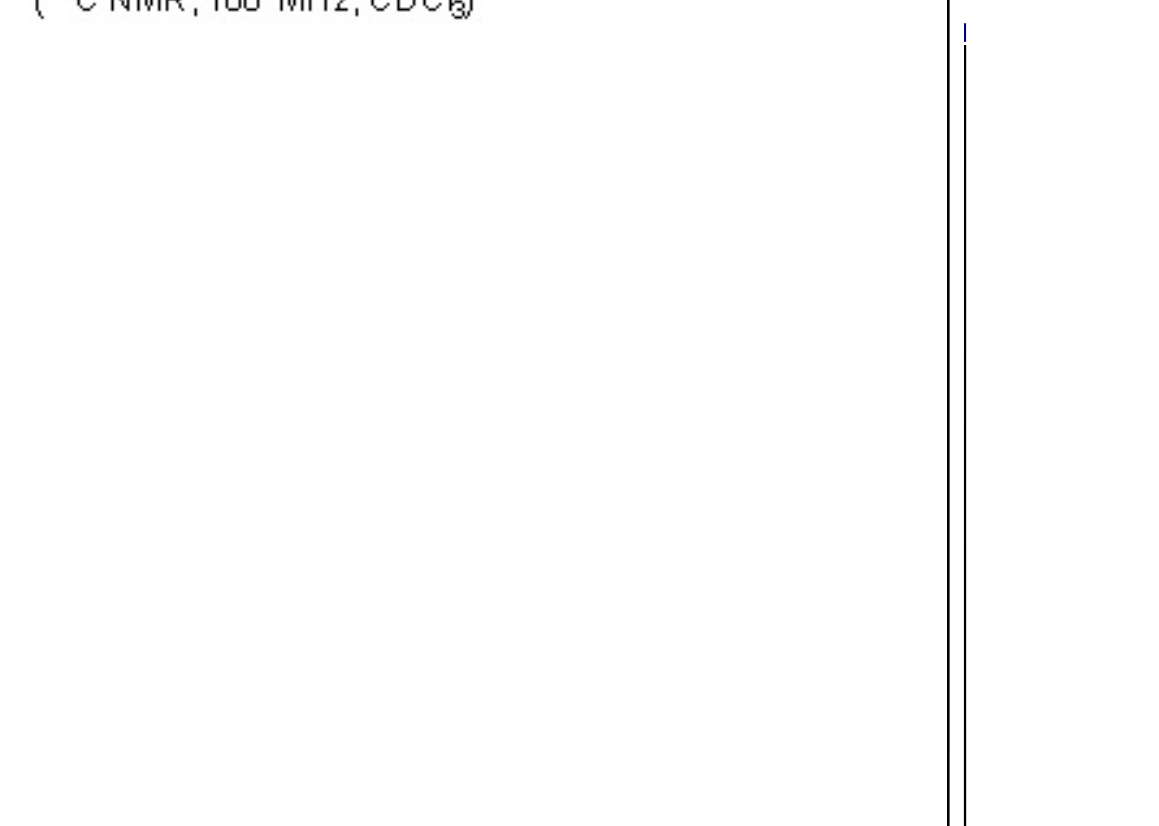

$\stackrel{\circ}{i}$

i̊ำ

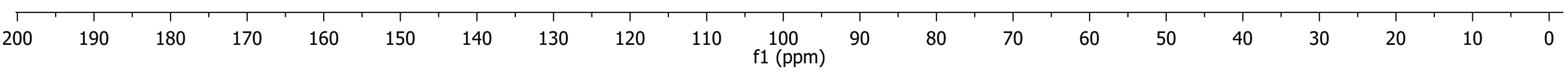




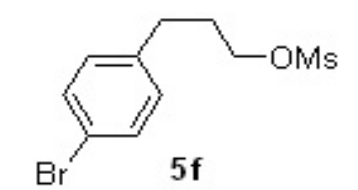

( $\left.{ }^{1} \mathrm{HNMR}, 400 \mathrm{MHz}, \mathrm{CDCl}_{3}\right)$

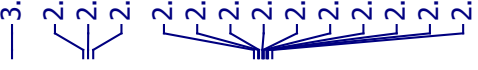




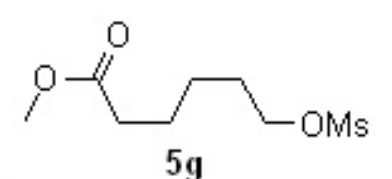

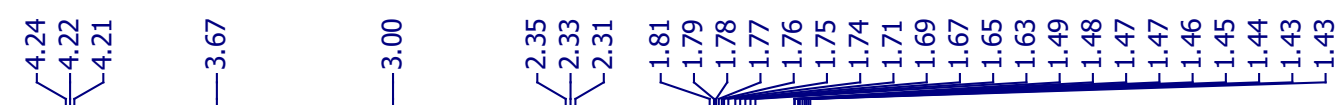

( $\left.{ }^{1} \mathrm{H} N \mathrm{MR}, 400 \mathrm{MHz}, \mathrm{CDCl}_{3}\right)$

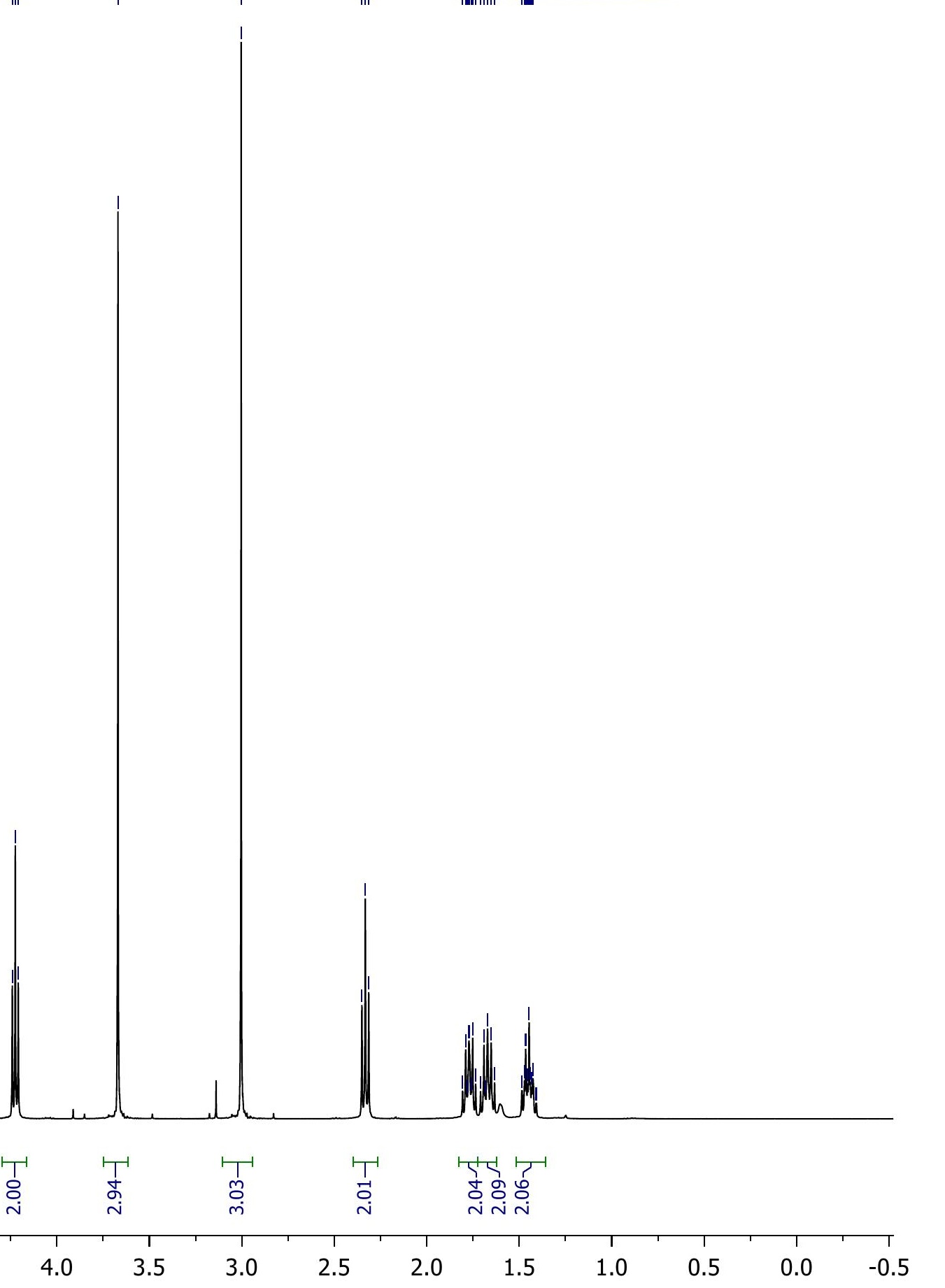




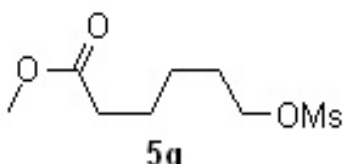

$\left({ }^{13} \mathrm{CNMR}, 100 \mathrm{MHz}, \mathrm{CDC} 3\right)$

$$
200
$$




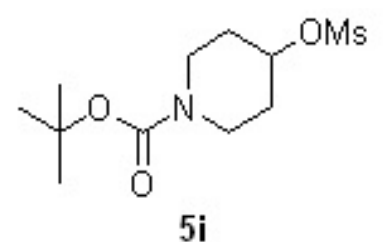

( ${ }^{1} \mathrm{HNMR}, 400 \mathrm{MHz}, \mathrm{CDC} 3$ )

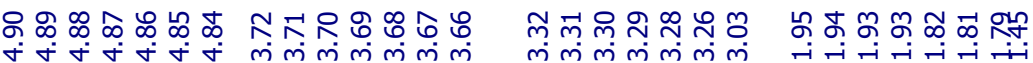

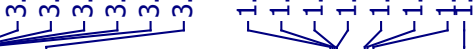

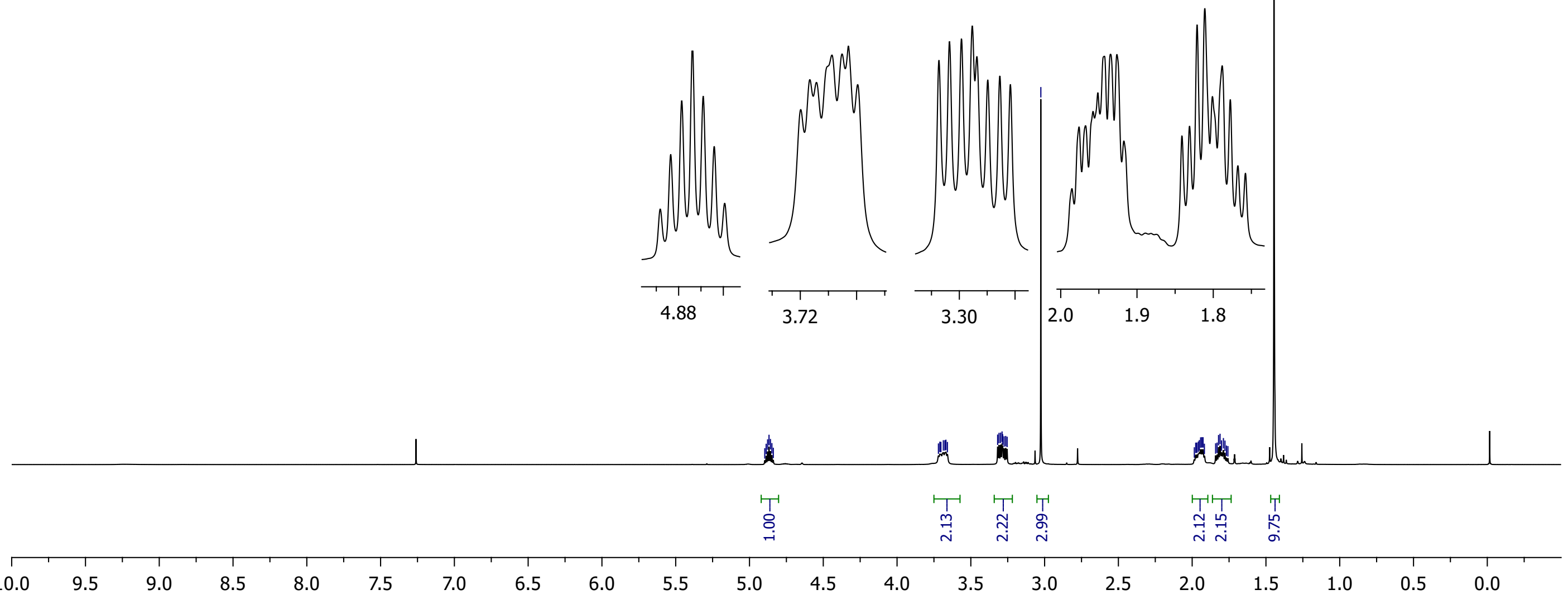



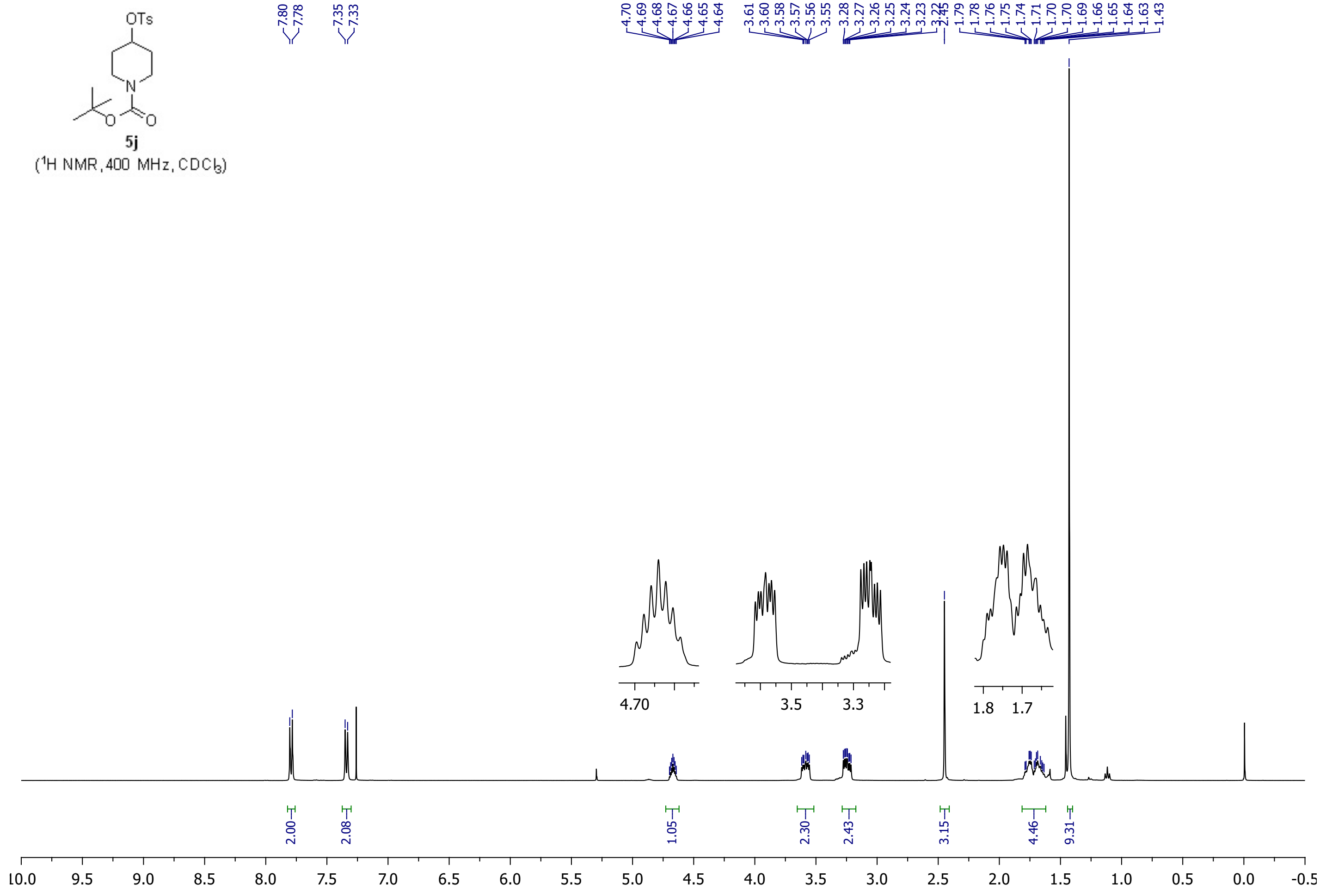


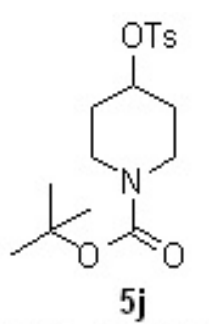

$\left({ }^{13} \mathrm{C} \mathrm{NMR}, 100 \mathrm{MHz}, \mathrm{CDCl}_{3}\right)$

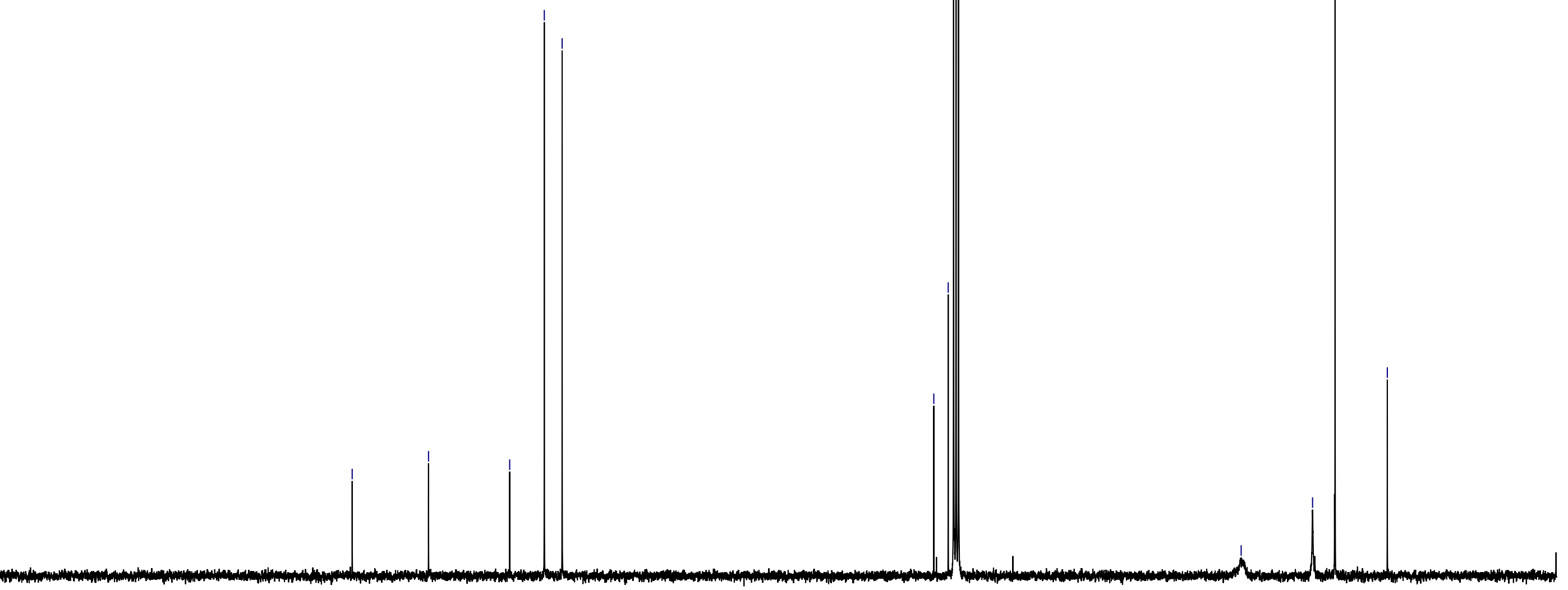




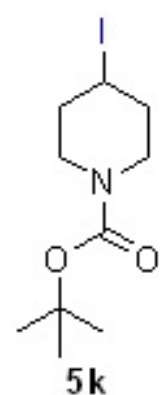

( ${ }^{1} \mathrm{H} N M R, 400 \mathrm{MHz}, \mathrm{CDCb}$ )

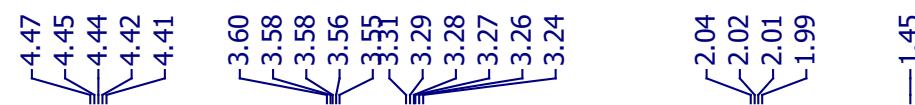
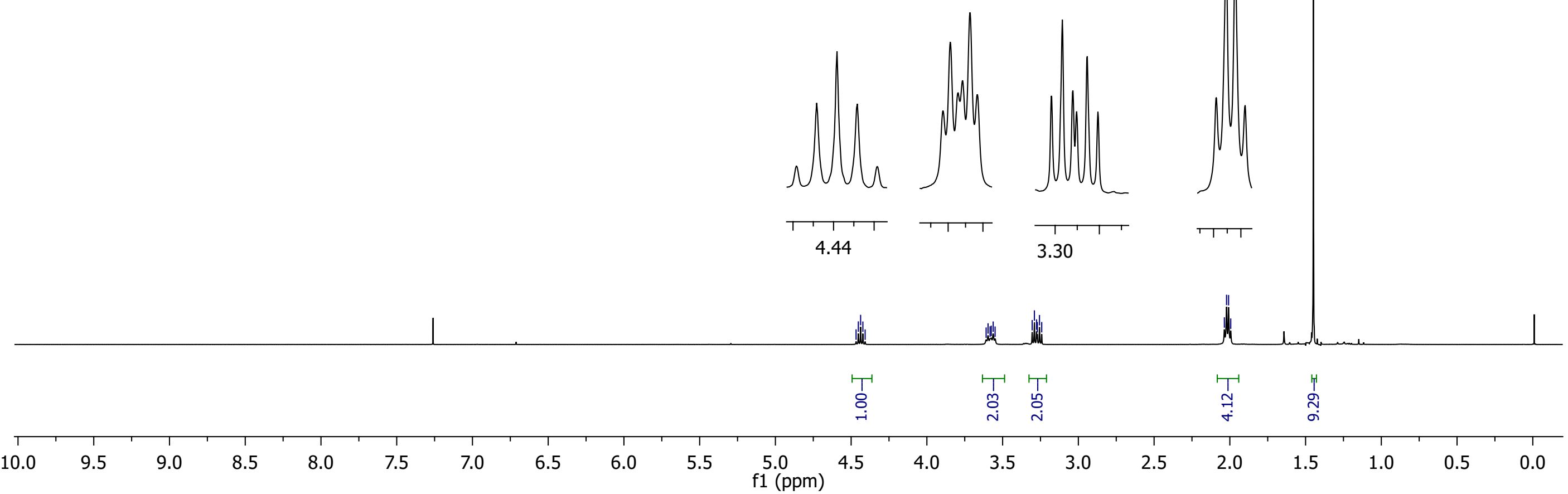


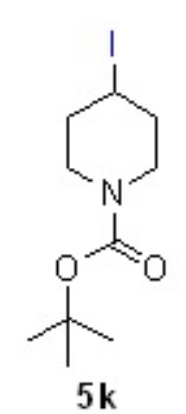

$\left({ }^{13} \mathrm{CNMR}, 100 \mathrm{MHz}, \mathrm{CDCl}_{3}\right)$

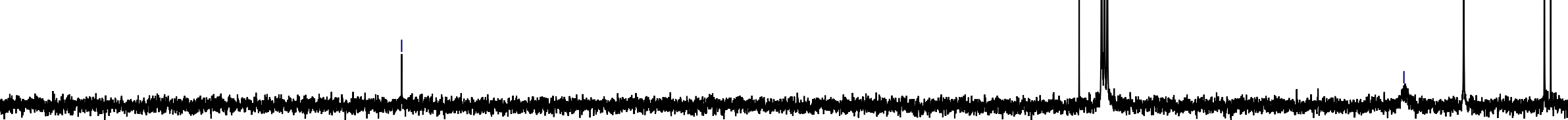

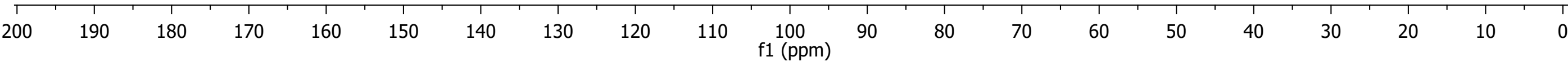




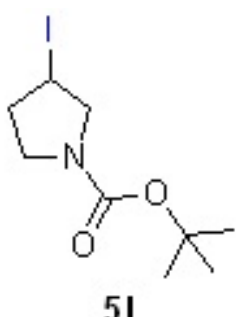

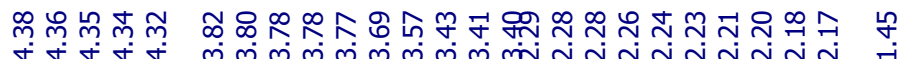

闫

( $\left.{ }^{1} \mathrm{HNMR}, 400 \mathrm{MHz}, \mathrm{CDCl}_{3}\right)$

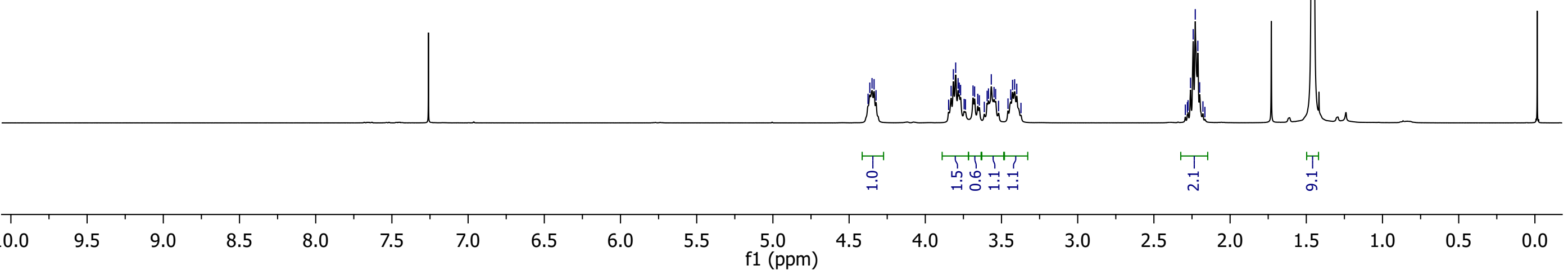




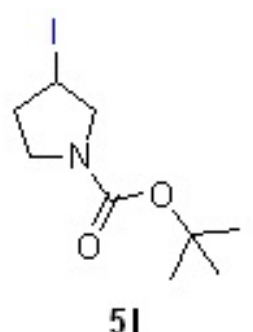

$\left({ }^{13} \mathrm{C} \mathrm{NMR}, 100 \mathrm{MHz}, \mathrm{CDCl}_{3}\right)$

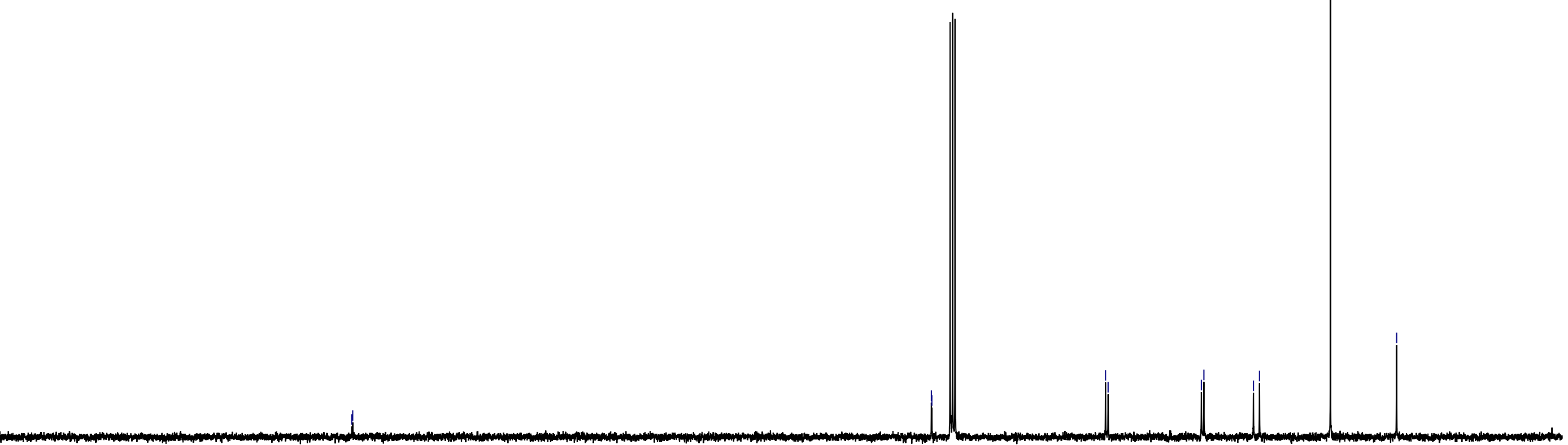

130




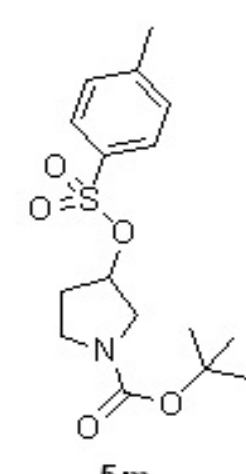

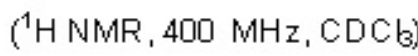




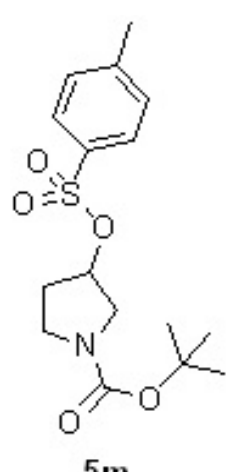

$\left({ }^{3} \mathrm{C} N M R, 100 \mathrm{MHz}, \mathrm{CDC} 6\right)$

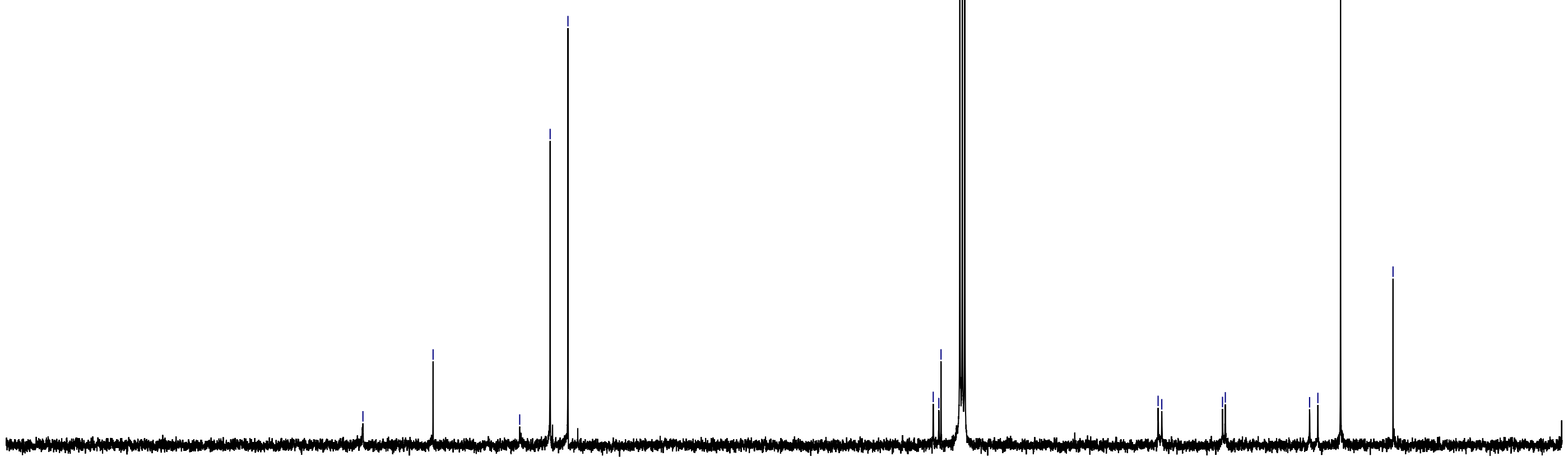




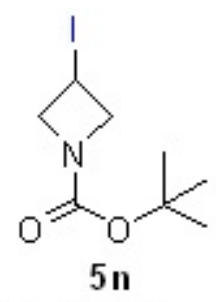

('H NMR, $400 \mathrm{MHz}, \mathrm{CDCb}$ )

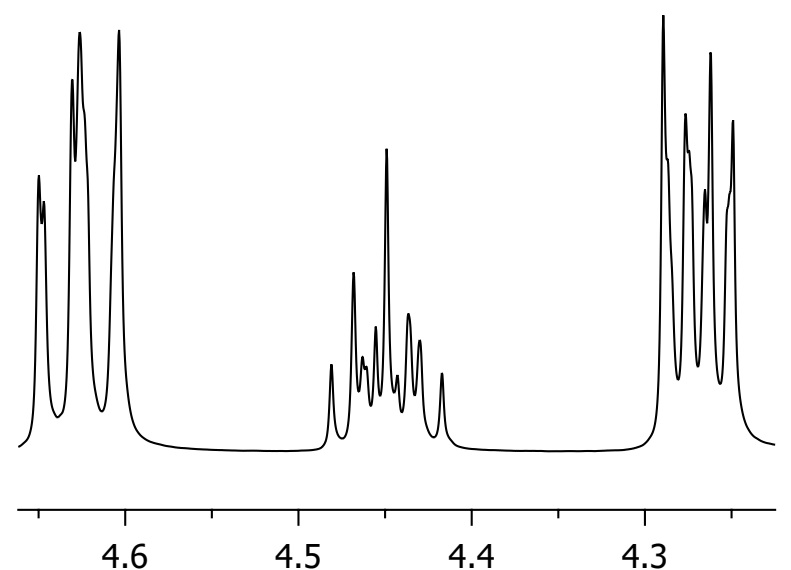

lal

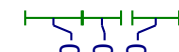

8 요요

\begin{tabular}{|c|c|c|c|c|c|c|c|c|c|c|c|c|c|c|c|c|c|c|c|c|}
\hline 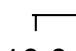 & 1 & 1 & 1 & 1 & 1 & 1 & 1 & 1 & 1 & 1 & 1 & 1 & 1 & 1 & 1 & 1 & 1 & 1 & 1 & 1 \\
\hline 10.0 & 9.5 & 9.0 & 8.5 & 8.0 & 7.5 & 7.0 & 6.5 & 6.0 & 5.5 & $\begin{array}{c}5.0 \\
\mathrm{f} 1 \text { (ppm) }\end{array}$ & 4.5 & 4.0 & 3.5 & 3.0 & 2.5 & 2.0 & 1.5 & 1.0 & 0.5 & 0.0 \\
\hline
\end{tabular}




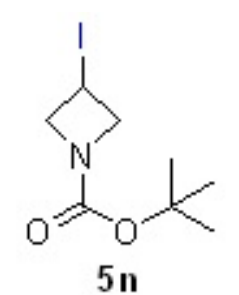

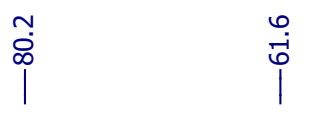

$\left({ }^{13} \mathrm{C} \mathrm{NMR}, 100 \mathrm{MHz}, \mathrm{CDCl}\right)$

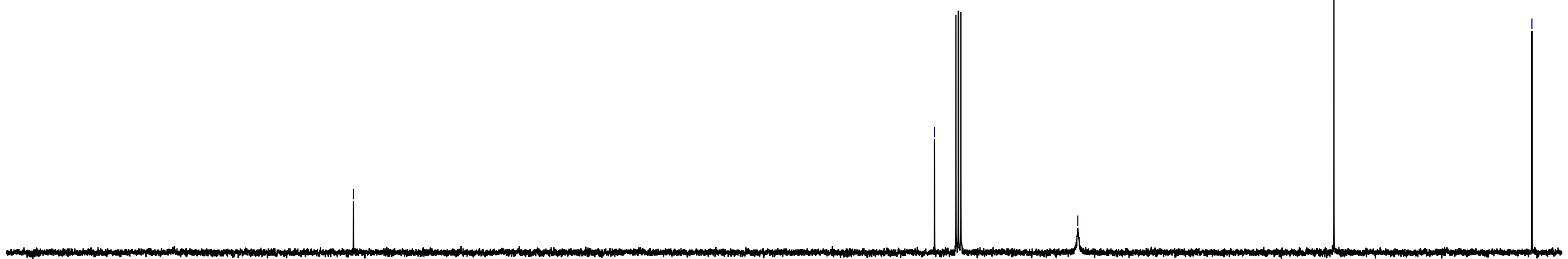

\begin{tabular}{|c|c|c|c|c|c|c|c|c|c|c|c|c|c|c|c|c|c|c|c|c|}
\hline$T$ & 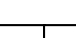 & 1 & 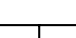 & $T_{1}$ & 1 & 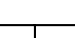 & 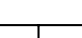 & 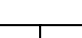 & $T$ & 1 & 7 & $T_{1}$ & $T_{1}$ & $T$ & $T_{1}$ & $T$ & $T_{1}$ & $T$ & $T_{1}$ & $T$ \\
\hline 200 & 190 & 180 & 170 & 160 & 150 & 140 & 130 & 120 & 110 & 100 & 90 & 80 & 70 & 60 & 50 & 40 & 30 & 20 & 10 & 0 \\
\hline
\end{tabular}




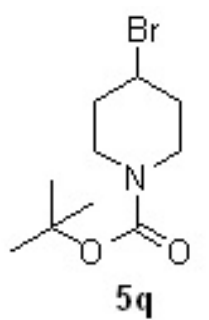

( $\left.{ }^{1} \mathrm{HNMR}, 400 \mathrm{MHz}, \mathrm{CDCl}_{3}\right)$

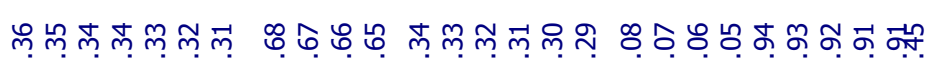

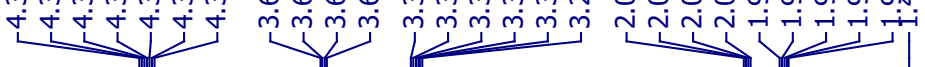
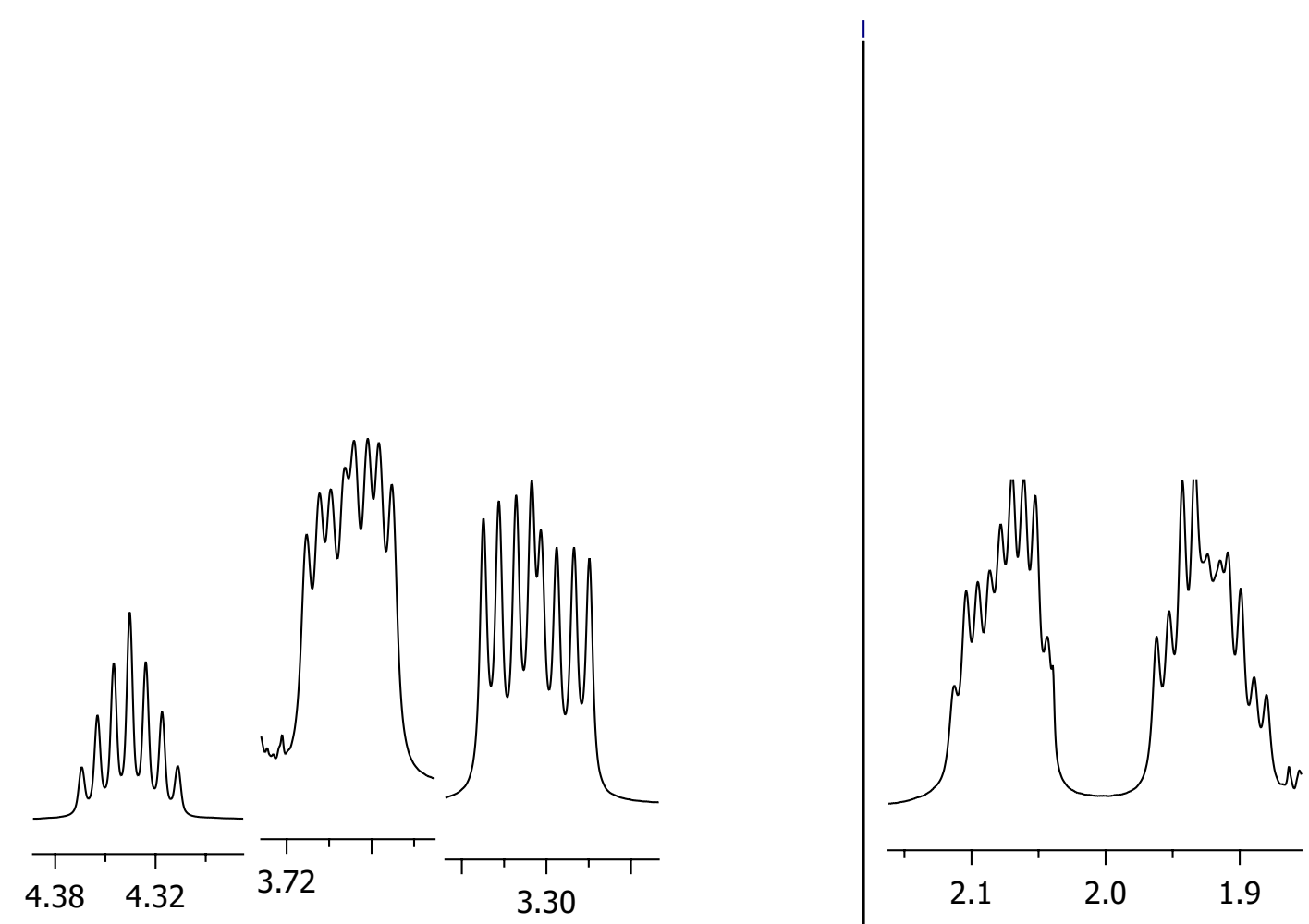

监

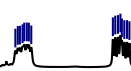

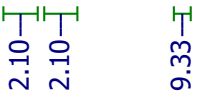

$2.0 \quad 1.5$

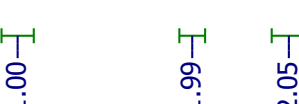

$\begin{array}{ll}4.0 & 3.5\end{array}$

2.5

1.5 


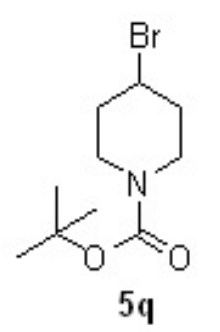

$\left({ }^{13} \mathrm{CNMR}, 100 \mathrm{MHz}, \mathrm{CDCl}\right.$ )

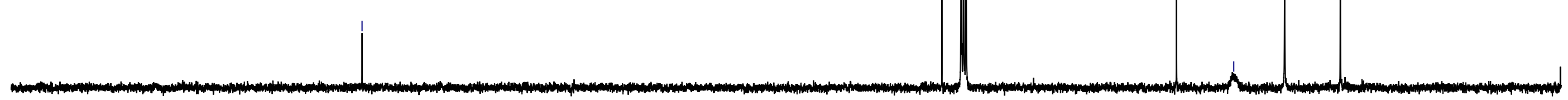




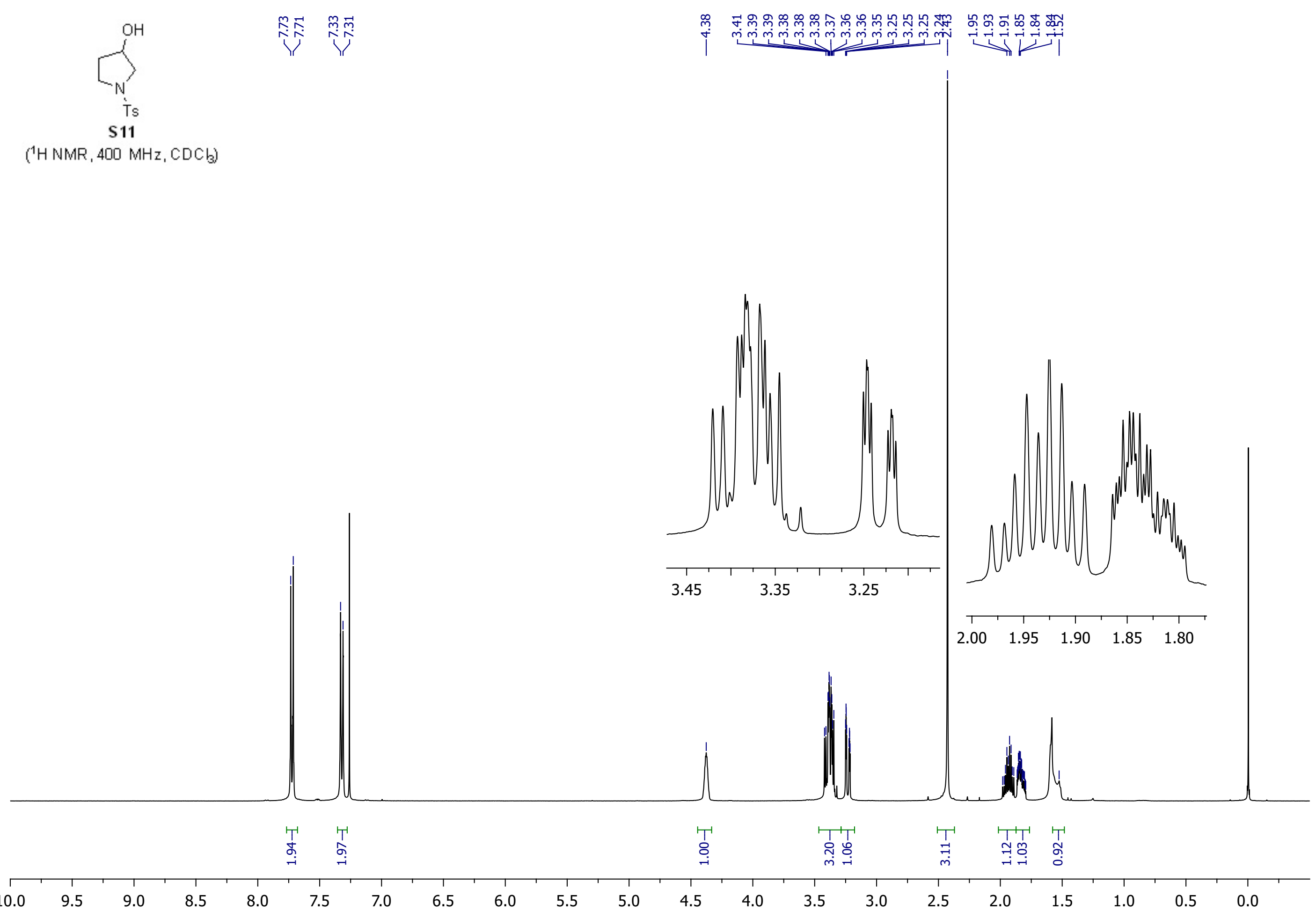




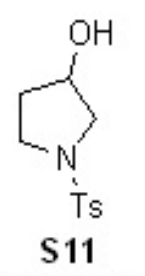

$\left({ }^{13} \mathrm{C} N M R, 100 \mathrm{MHz}, \mathrm{CDCb}_{3}\right)$

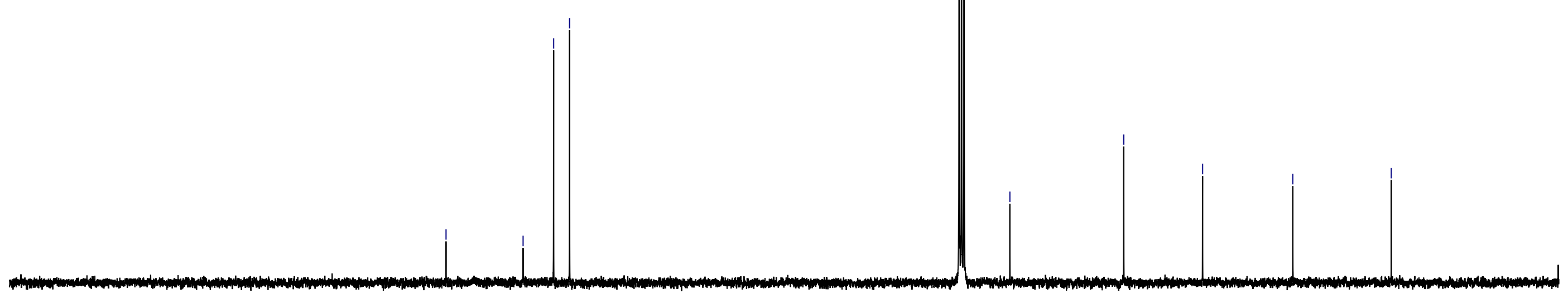




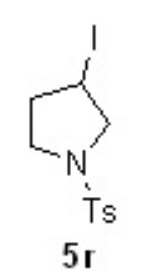

$\left({ }^{1} \mathrm{HNMR}, 400 \mathrm{MHz}, \mathrm{CDCl}_{3}\right)$
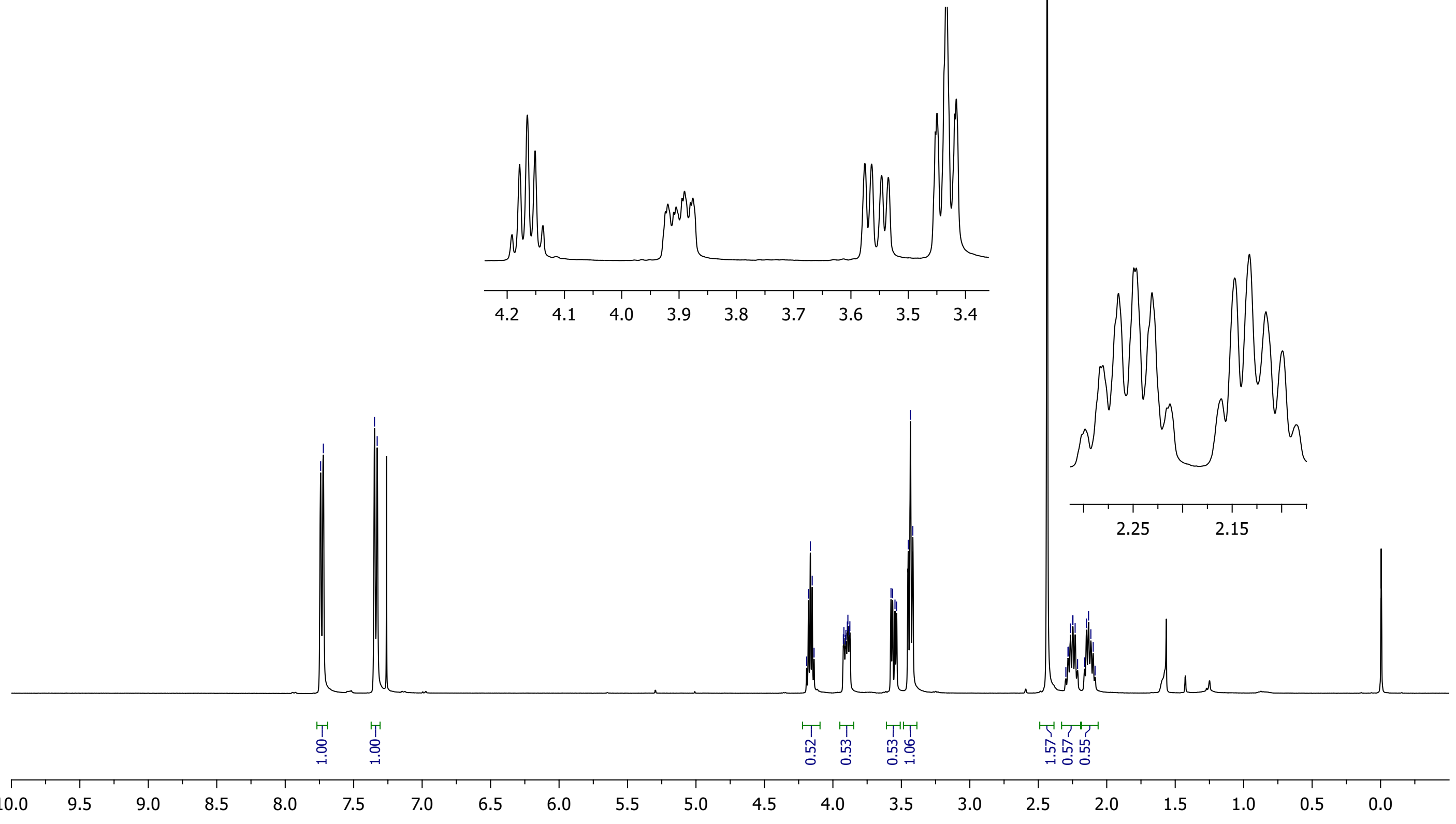


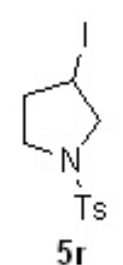

$\left({ }^{13} \mathrm{C} N M R, 100 \mathrm{MHz}, \mathrm{CDCb}\right)$

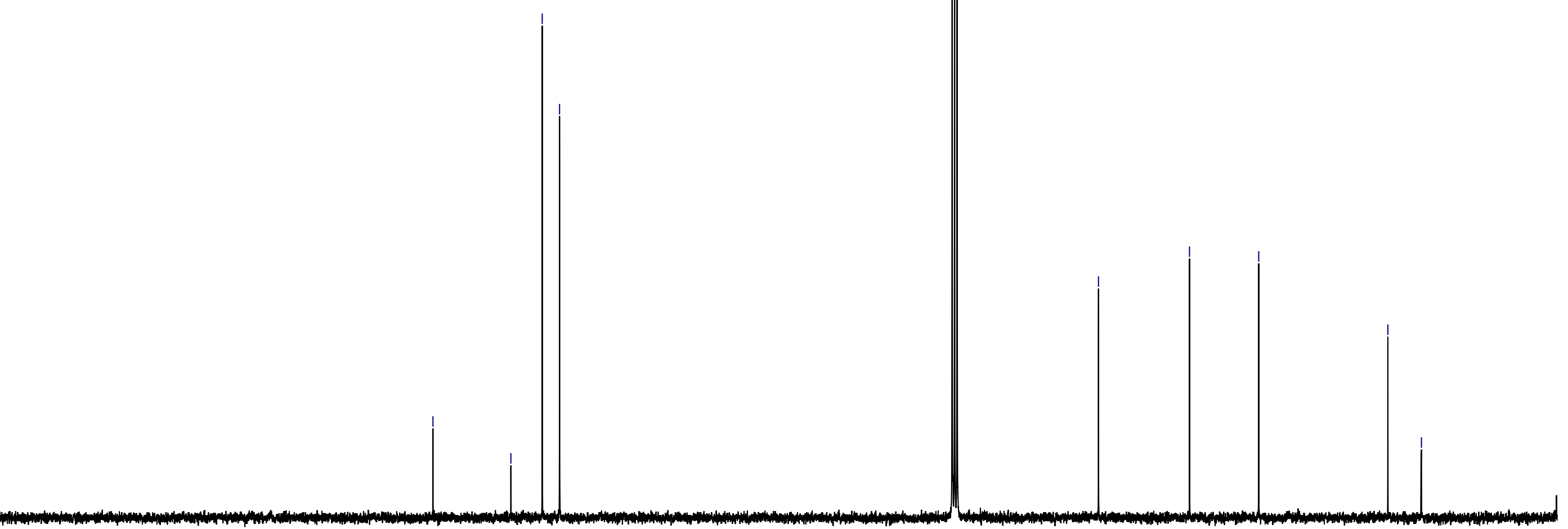




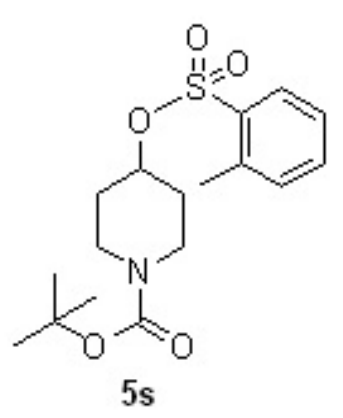

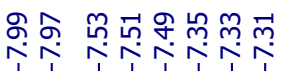

ए人诸

( $\left.{ }^{1} \mathrm{HNMR}, 400 \mathrm{MHz}, \mathrm{CDCl}_{3}\right)$

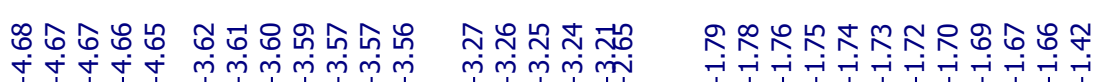

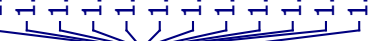

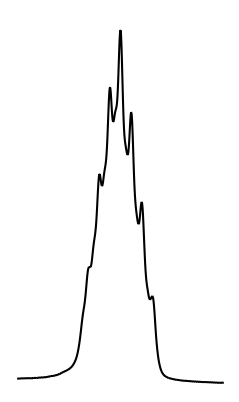

4.59

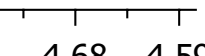

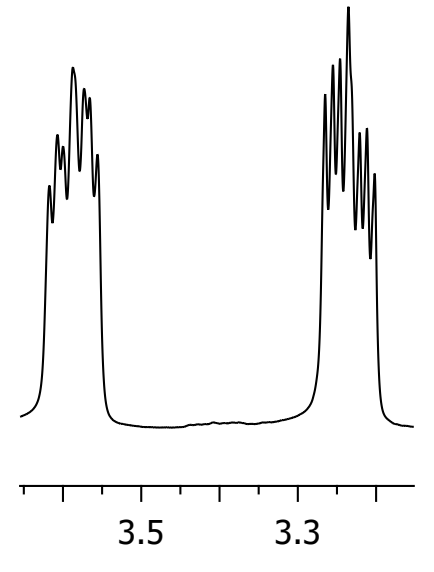

(u)
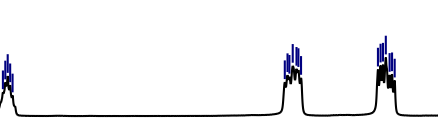

w

1.8

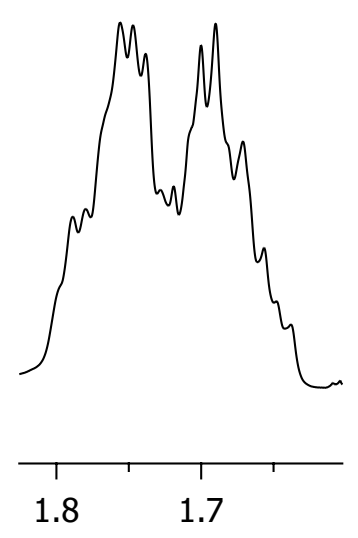

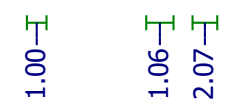

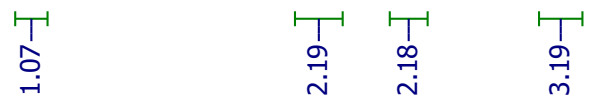

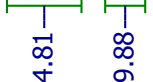




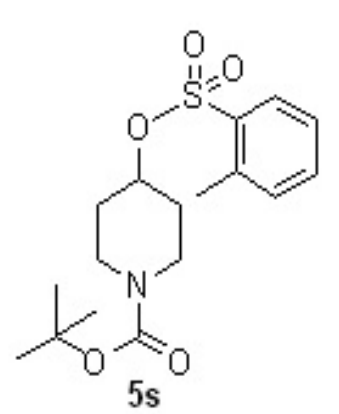




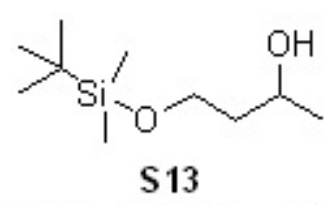

( ${ }^{1} \mathrm{HNMR}, 400 \mathrm{MHz}, \mathrm{CDCb}$ )
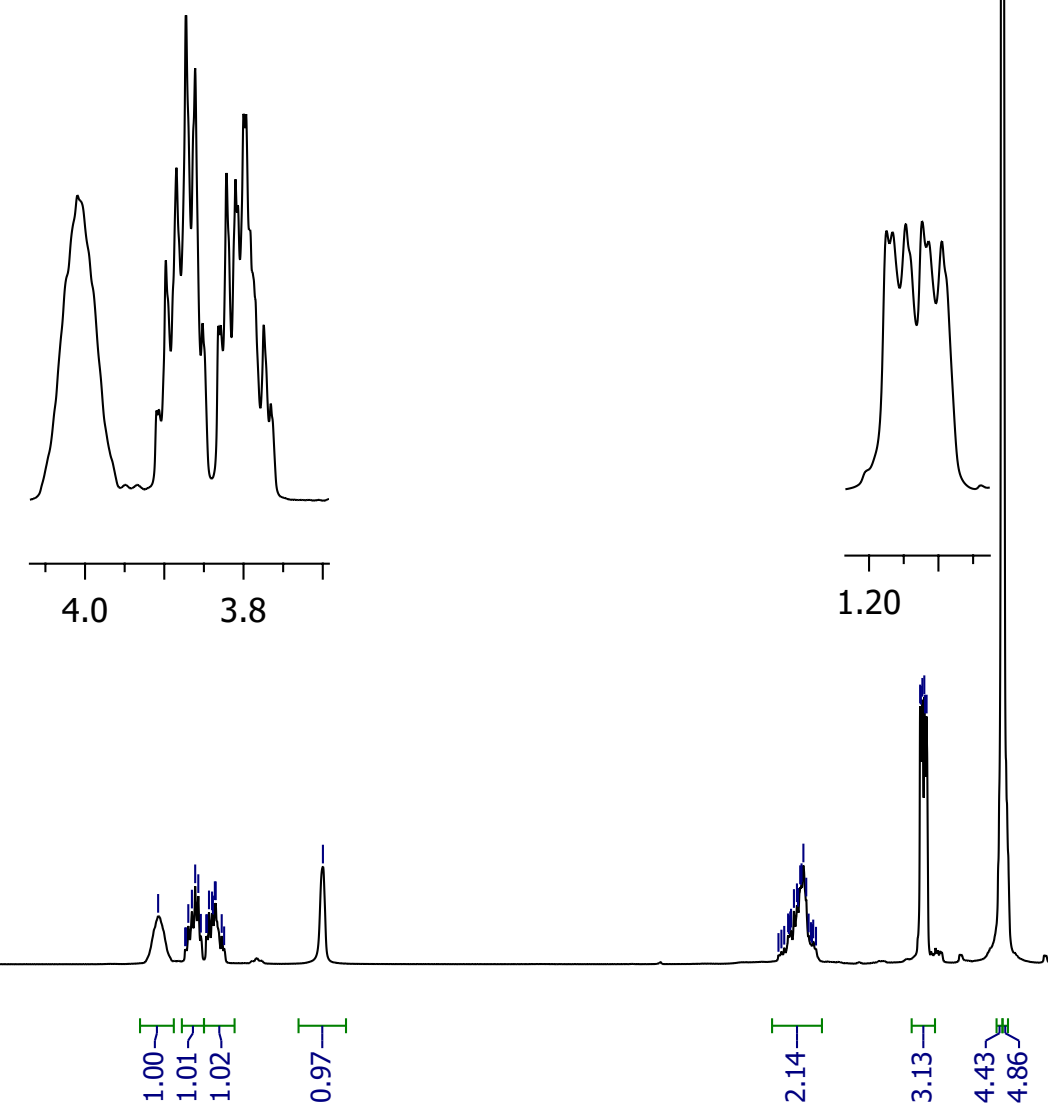


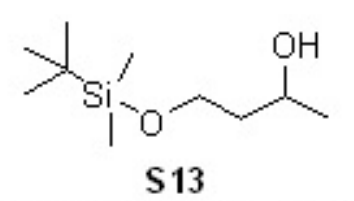

$\left({ }^{13} \mathrm{C} \mathrm{NMR}, 100 \mathrm{MHz}, \mathrm{CDCl}_{3}\right)$ 
( $\left.{ }^{1} \mathrm{HNMR}, 400 \mathrm{MHz}, \mathrm{CDCb}\right)$
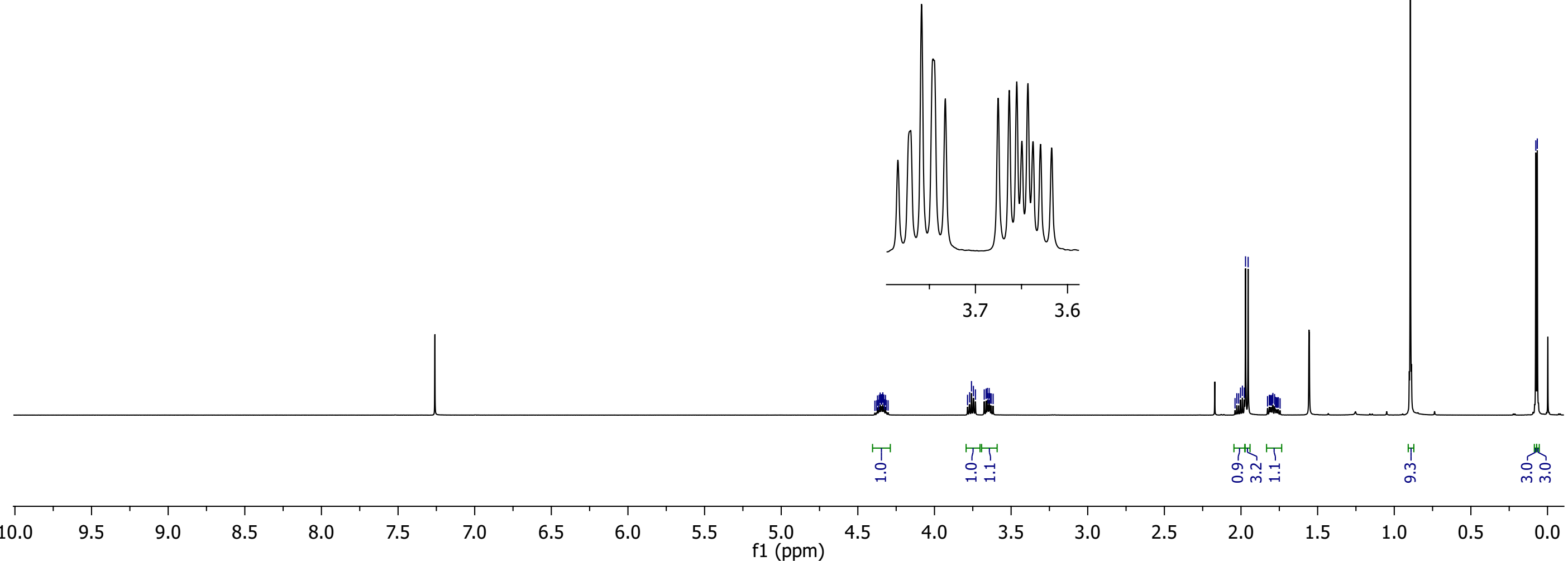


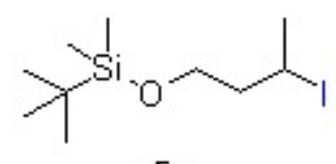

$\left({ }^{13} \mathrm{C} \mathrm{NMR}, 100 \mathrm{MHz}, \mathrm{CDCb}\right)$

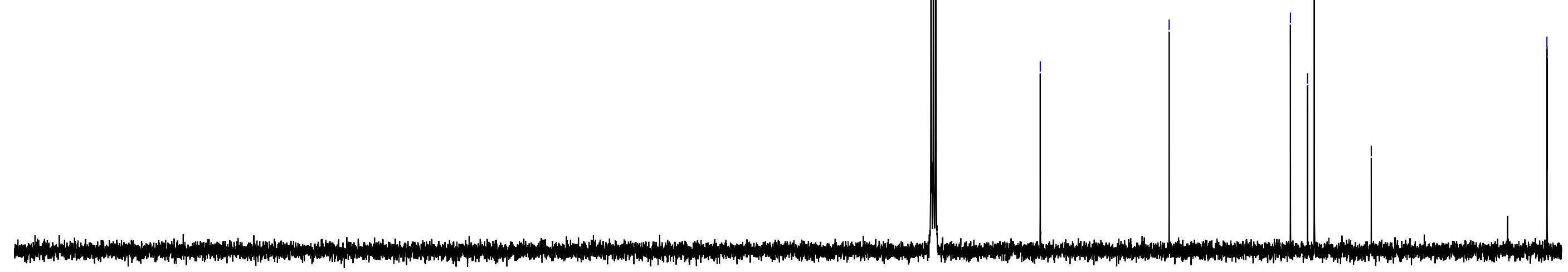

\begin{tabular}{|c|c|c|c|c|c|c|c|c|c|c|c|c|c|c|c|c|c|c|c|}
\hline$T$ & 1 & 1 & 1 & 1 & 1 & 1 & 1 & 1 & 1 & 1 & 1 & 1 & 1 & 1 & 1 & 1 & 1 & 1 & $T$ \\
\hline 200 & 190 & 180 & 170 & 160 & 150 & 140 & 130 & 120 & 110 & $\begin{array}{l}100 \\
\mathrm{f} 1(\mathrm{ppm})\end{array} 90$ & 80 & 70 & 60 & 50 & 40 & 30 & 20 & 10 & 0 \\
\hline
\end{tabular}




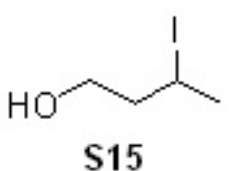

( $\left.{ }^{1} \mathrm{H} N M R, 400 \mathrm{MHz}, \mathrm{CDCl}\right)$
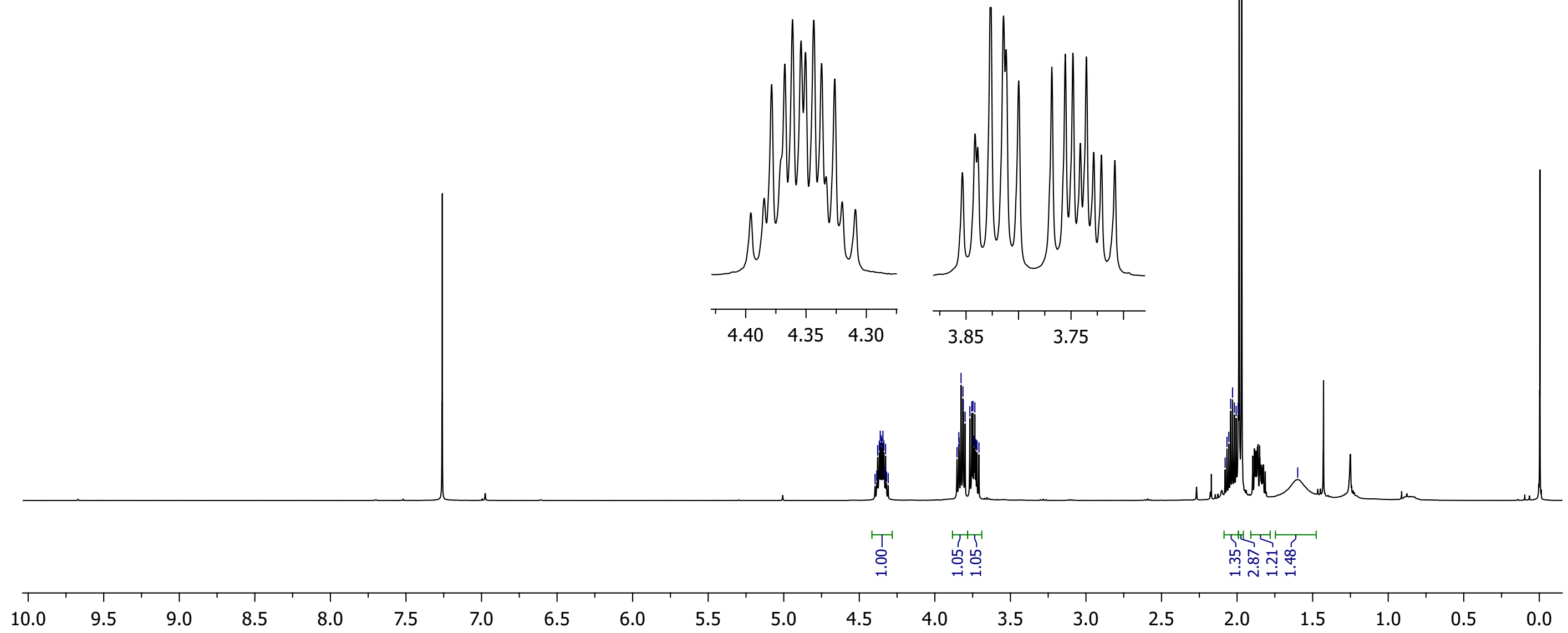


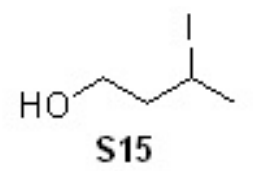

$\left({ }^{13} \mathrm{C} \mathrm{NMR}, 100 \mathrm{MHz}, \mathrm{CDCl}\right)$

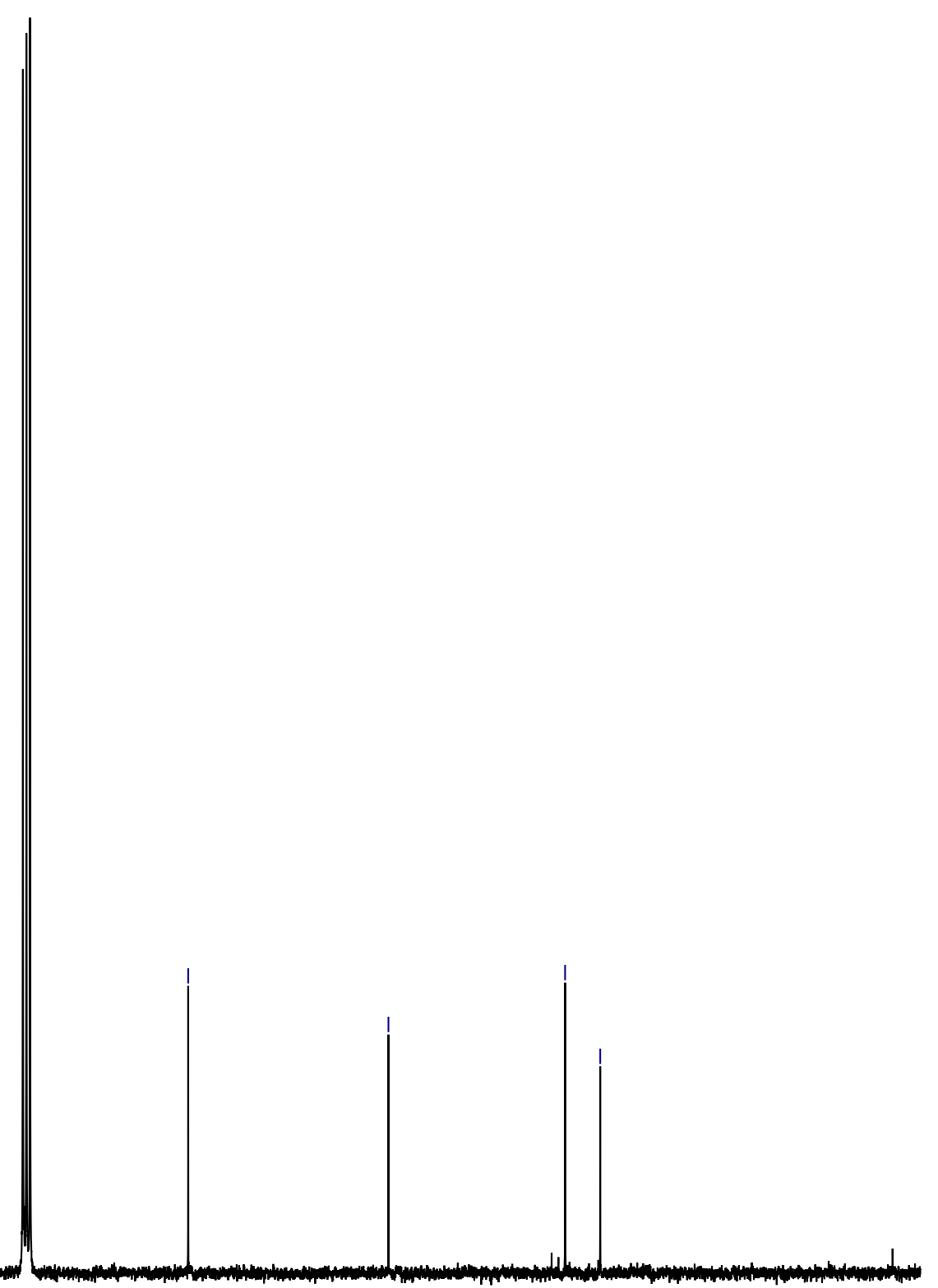




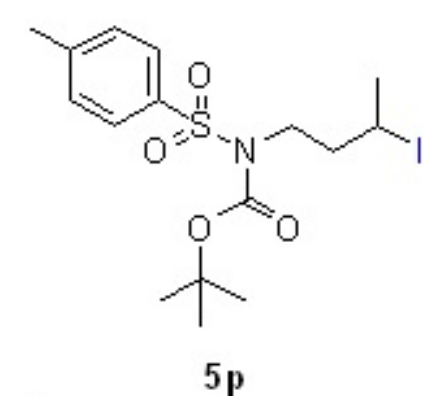

( $\left.{ }^{1} \mathrm{H} N M R, 400 \mathrm{MHz}, \mathrm{CDCb}\right)$
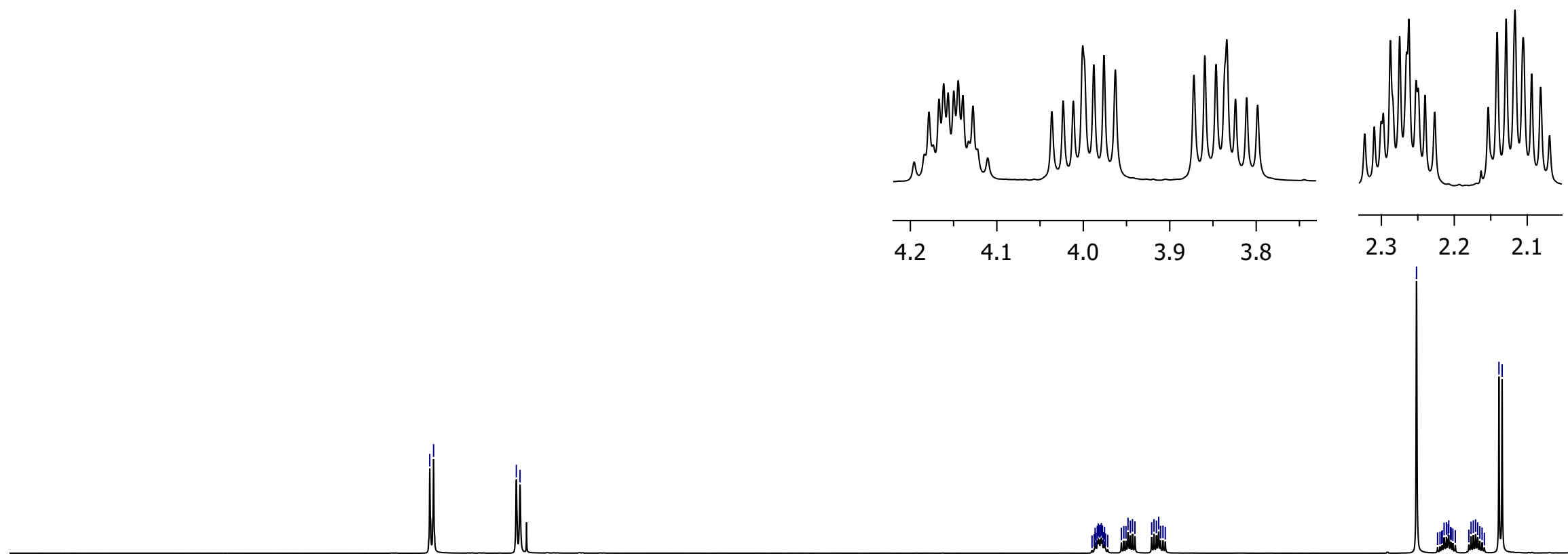

A
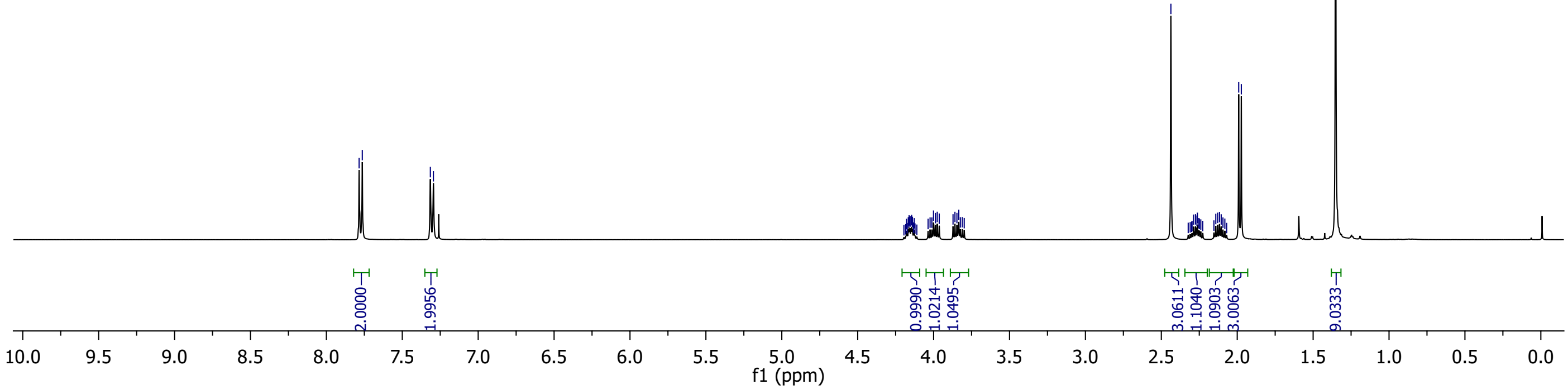


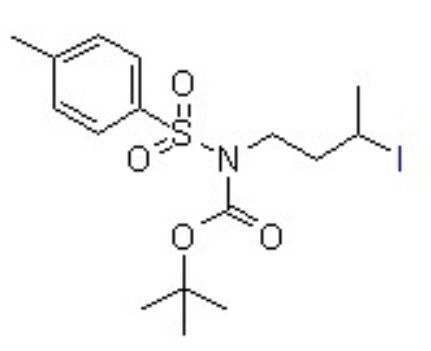

$5 p$

$\left({ }^{13} \mathrm{CNMR}, 100 \mathrm{MHz}, \mathrm{CDCl}\right)$ i

$\stackrel{\substack{+\infty \\ \infty}}{i}$

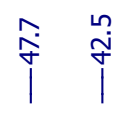

ํํํㅇํㄹ
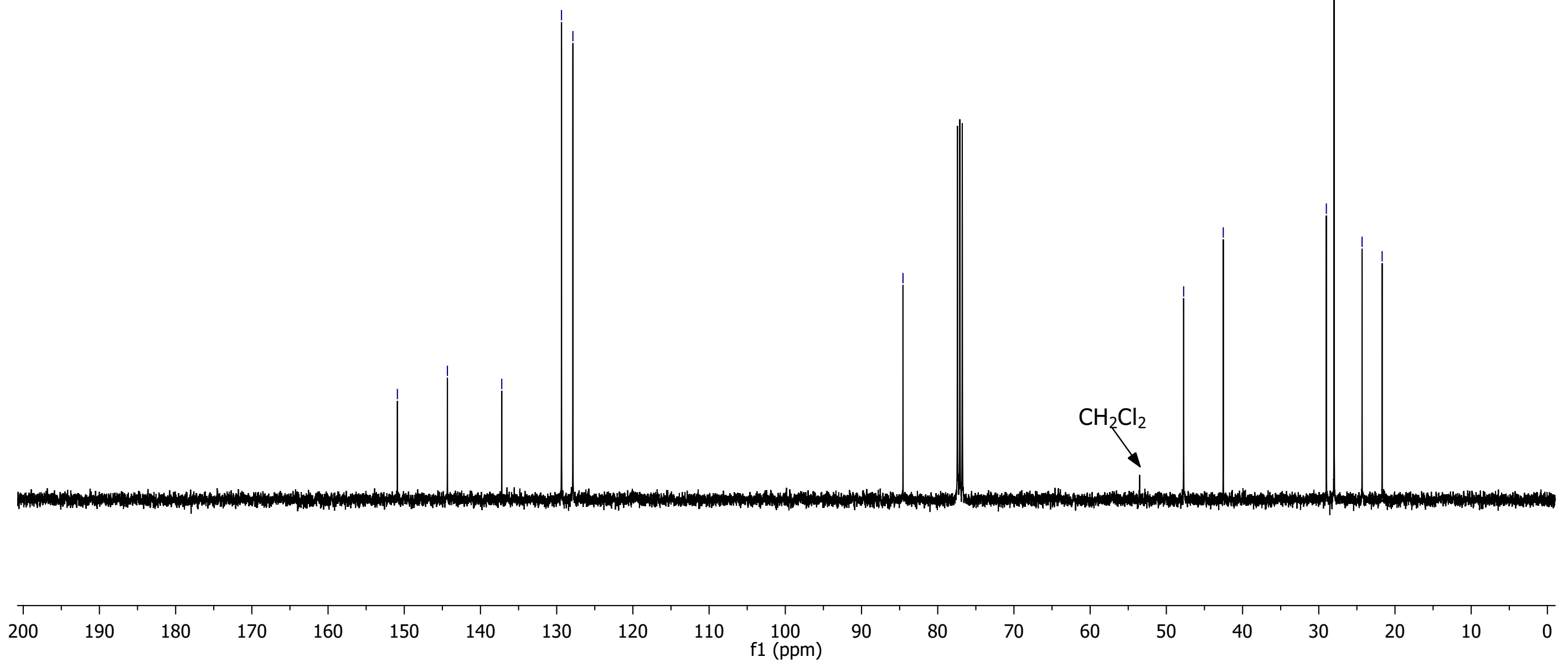


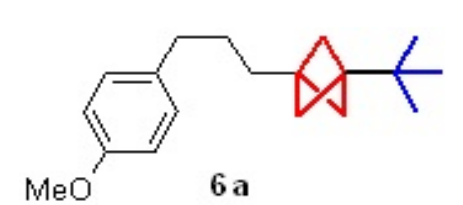

( ${ }^{\mathrm{H} N M R}, 400 \mathrm{MHz}, \mathrm{CDCl}$ )
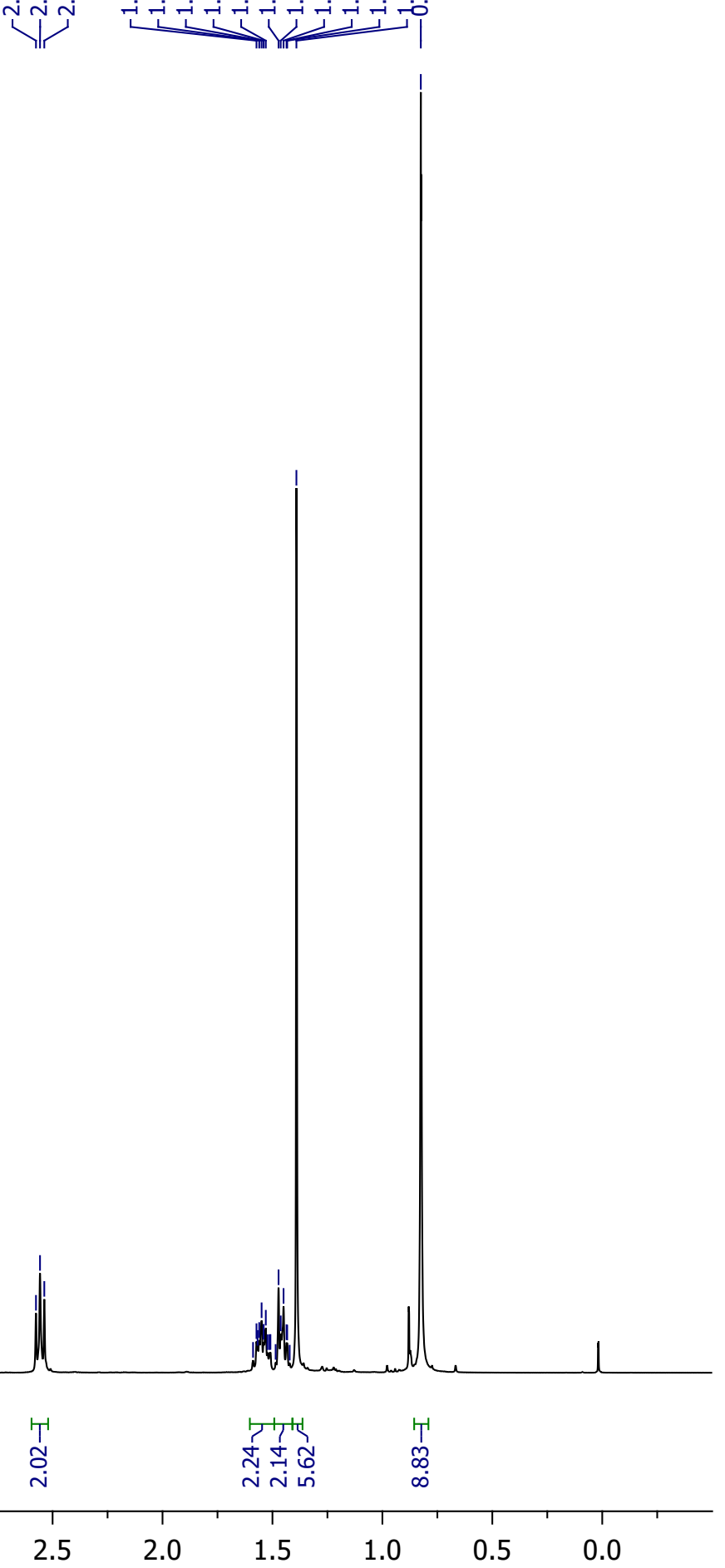

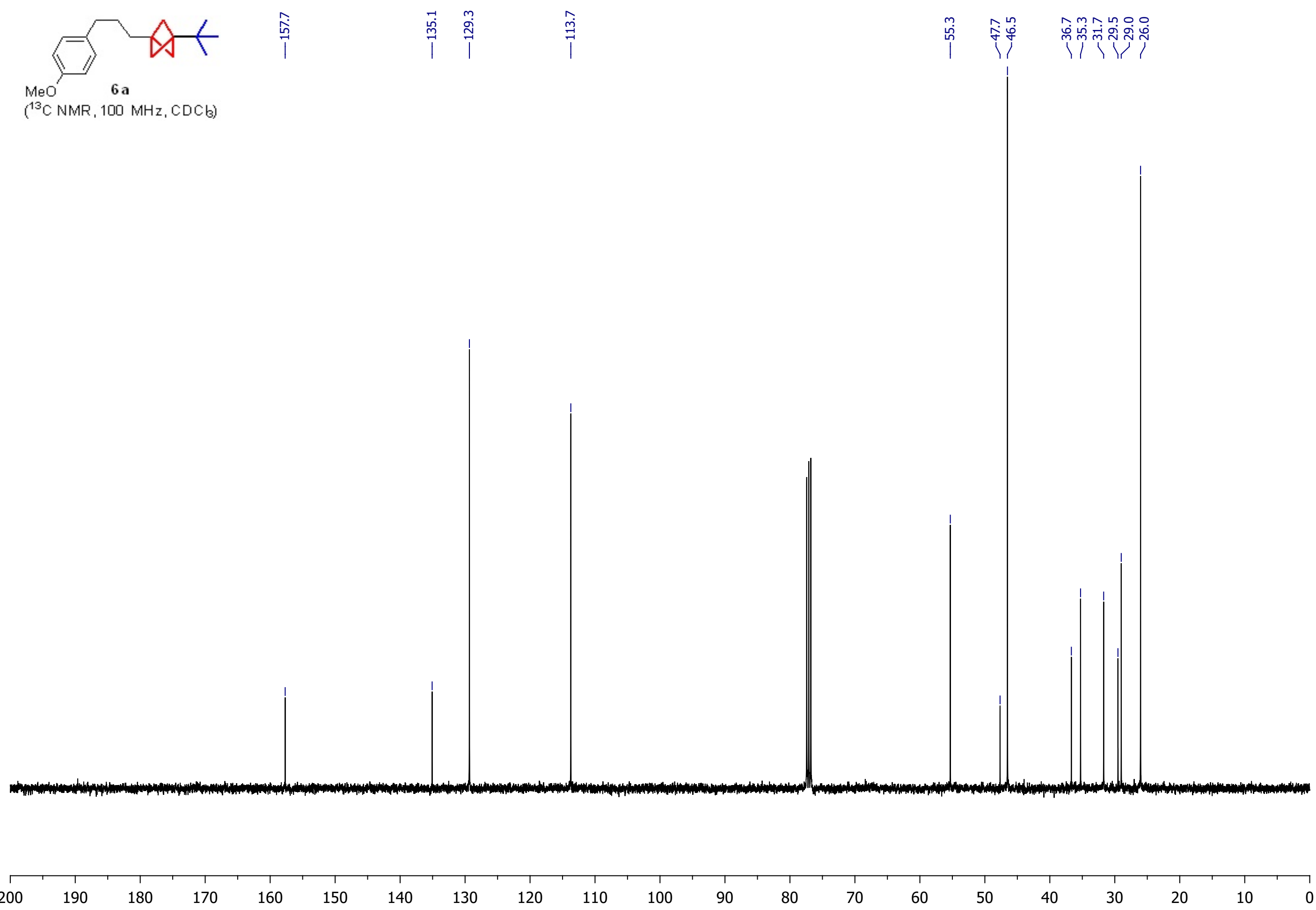


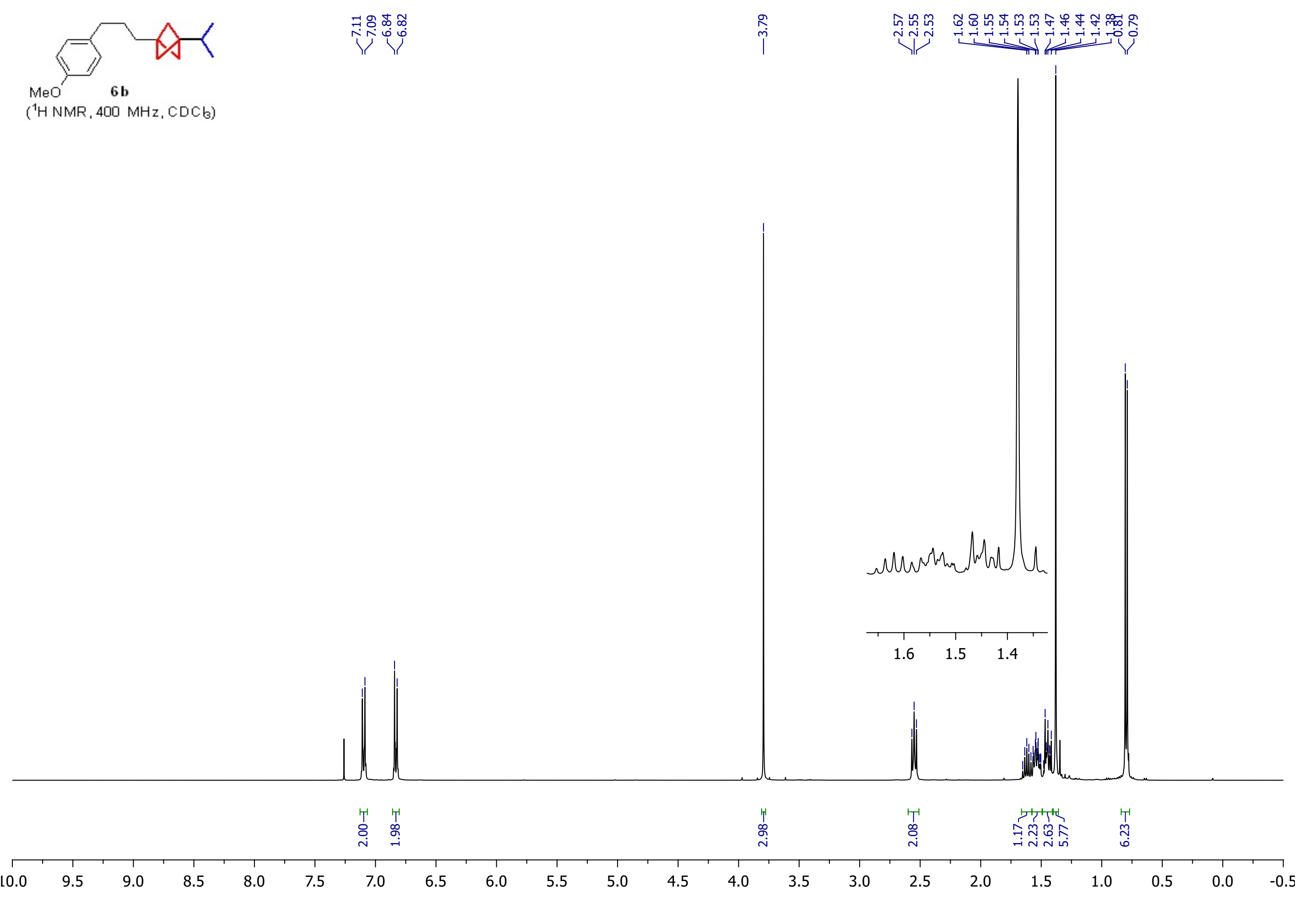




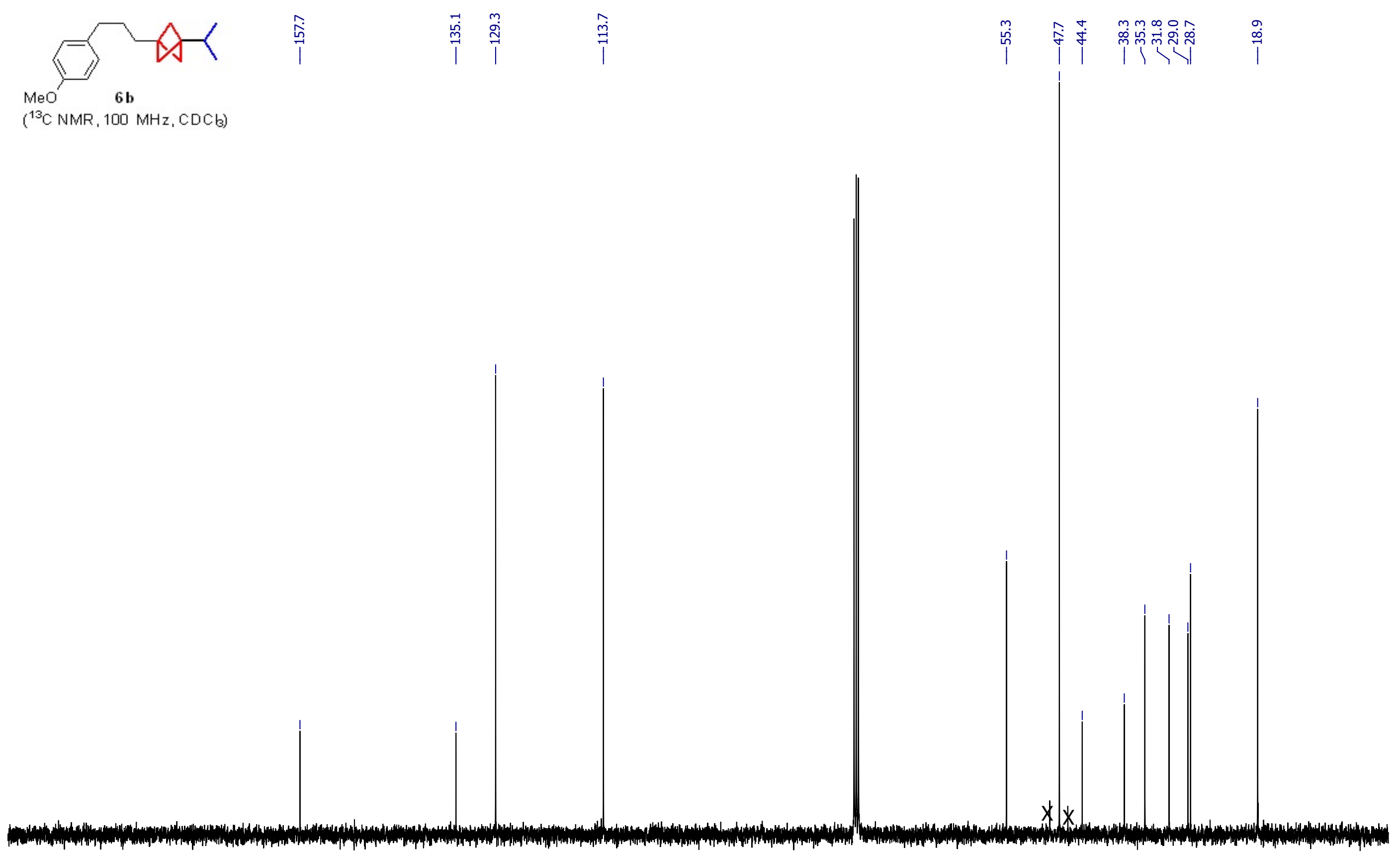

\begin{tabular}{|c|c|c|c|c|c|c|c|c|c|c|c|c|c|c|c|c|c|c|c|}
\hline 200 & 190 & 180 & 170 & 160 & $\begin{array}{l}1 \\
150\end{array}$ & 140 & 130 & $\begin{array}{l}1 \\
120\end{array}$ & 110 & 100 & 90 & 80 & $\begin{array}{l}1 \\
70\end{array}$ & 60 & 50 & 40 & 30 & 20 & 10 \\
\hline
\end{tabular}



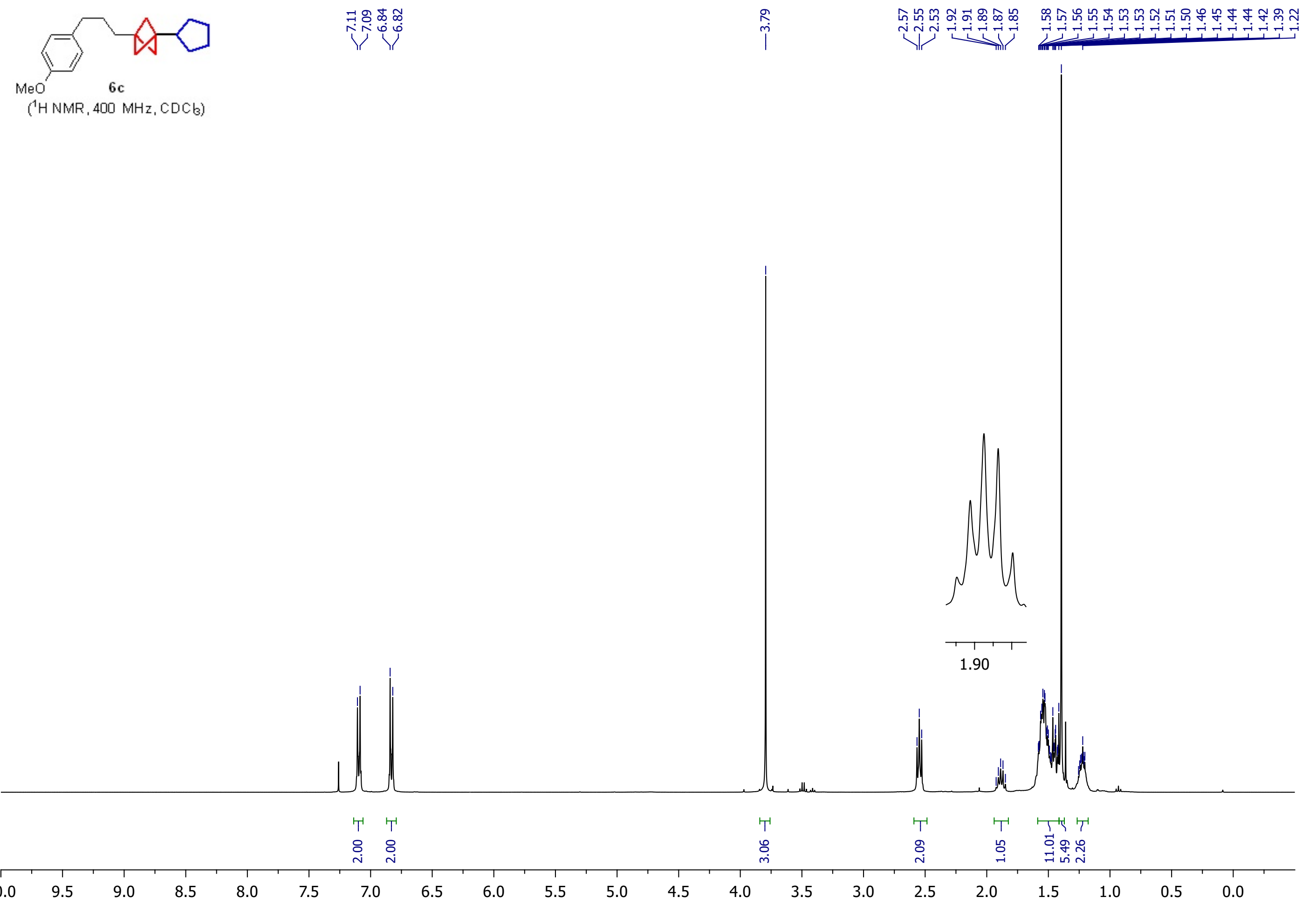


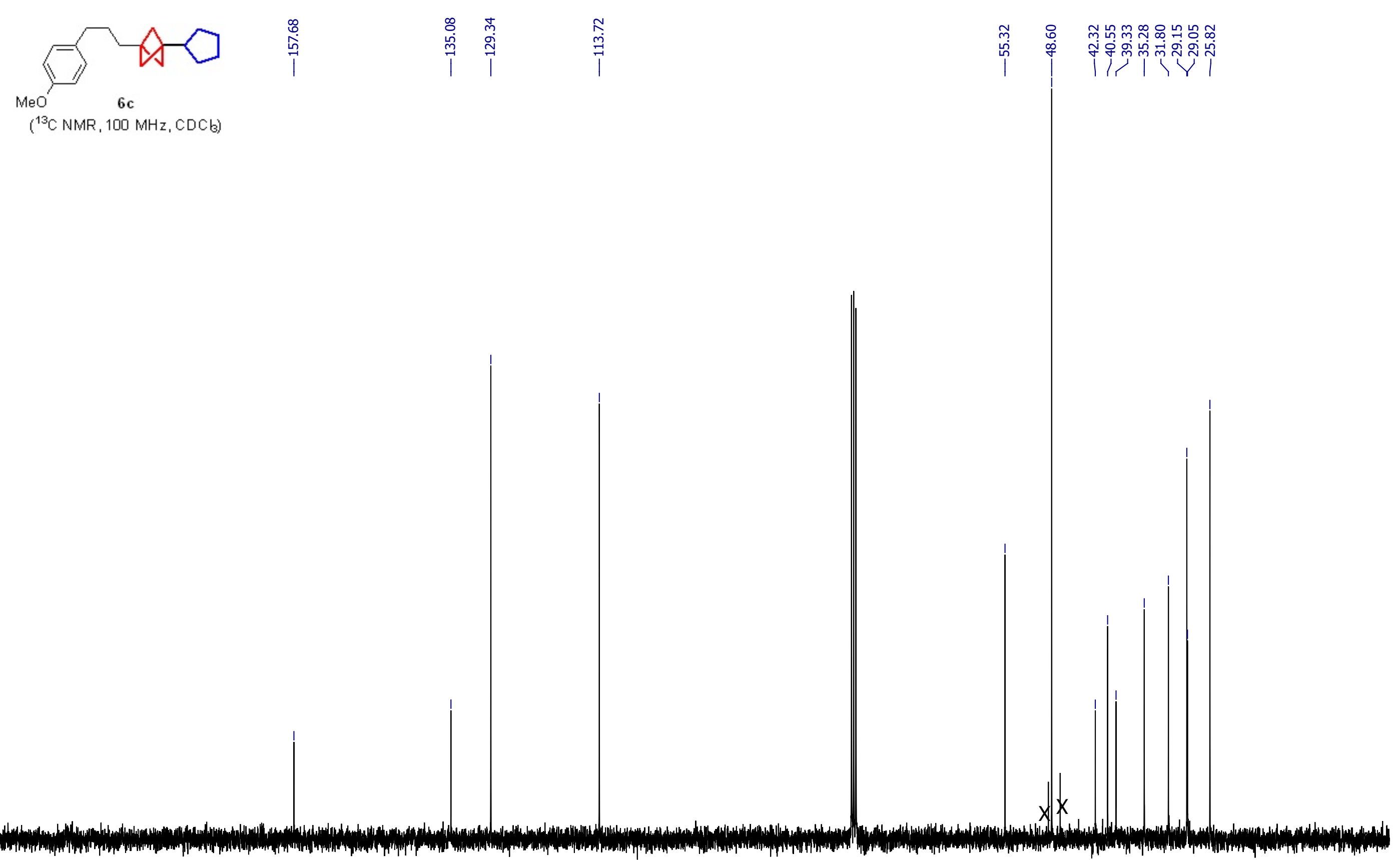

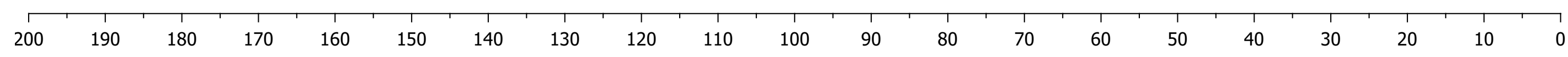




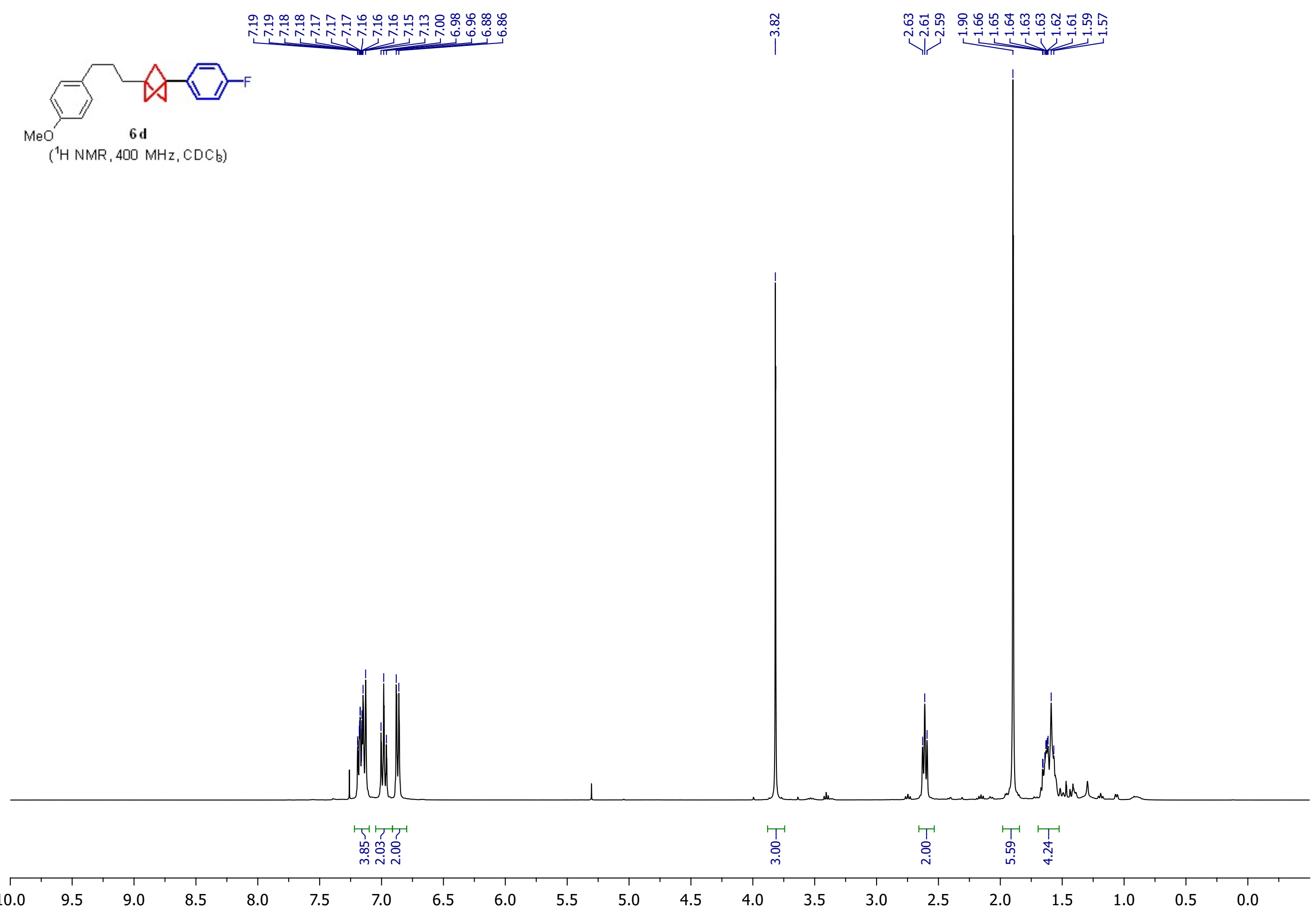




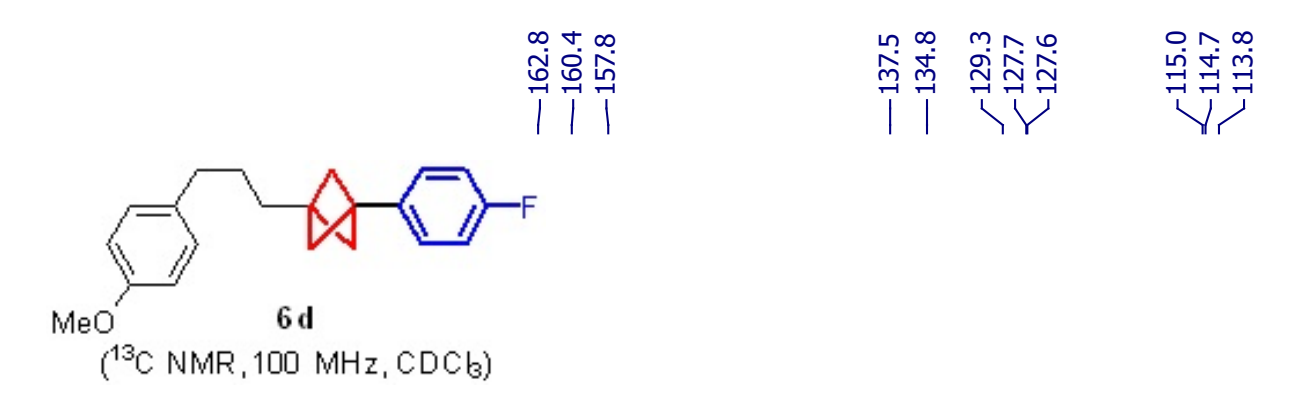

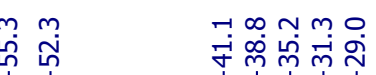

। ।

$\left({ }^{13} \mathrm{C} \mathrm{NMR}, 100 \mathrm{MHz}, \mathrm{CDCl}\right)$

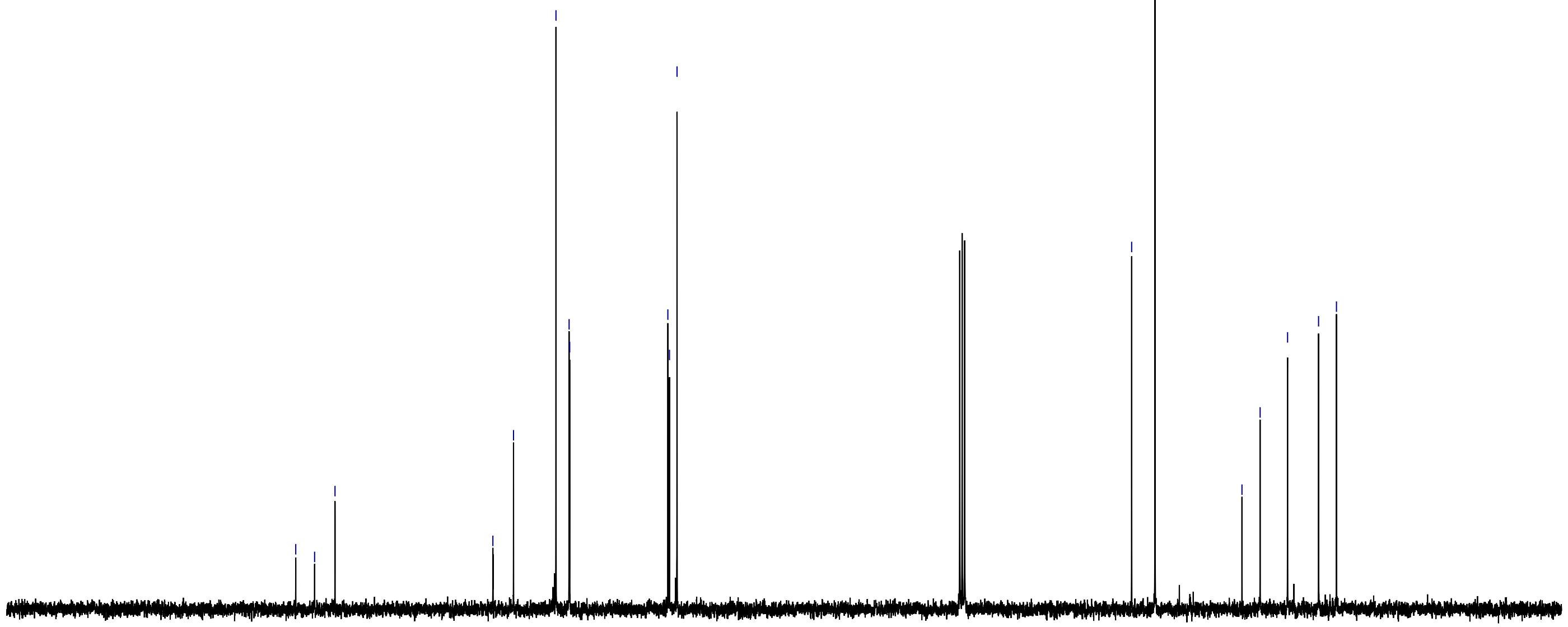




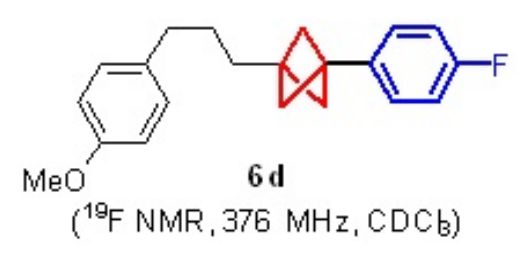

\section{$\left({ }^{19} \mathrm{~F} \mathrm{NMR}, 376 \mathrm{MHz}, \mathrm{CDCB}\right)$}




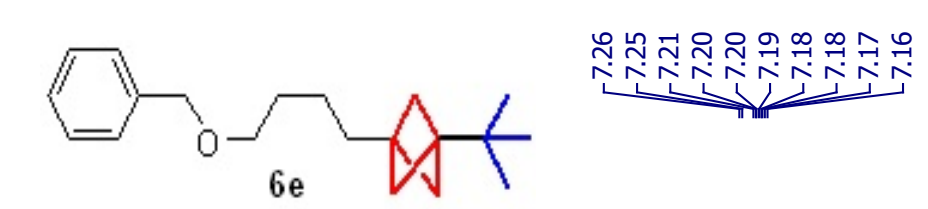

( ${ }^{1} \mathrm{H} N M R, 400 \mathrm{MHz}, \mathrm{CDCl}$ )

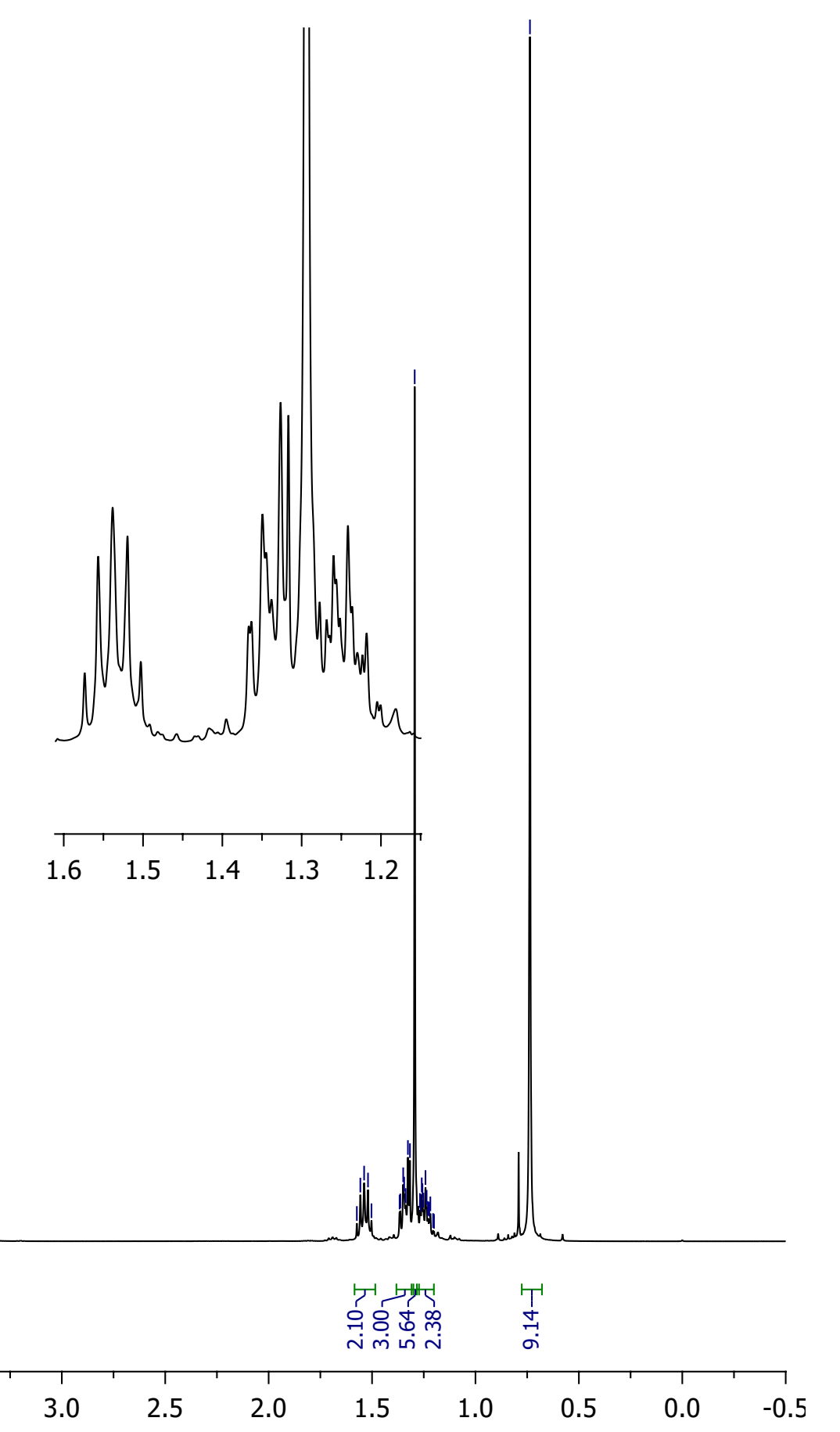




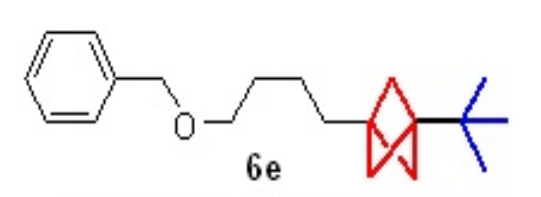

$\left({ }^{13} \mathrm{CNMR}, 100 \mathrm{MHz}, \mathrm{CDC} 6\right)$
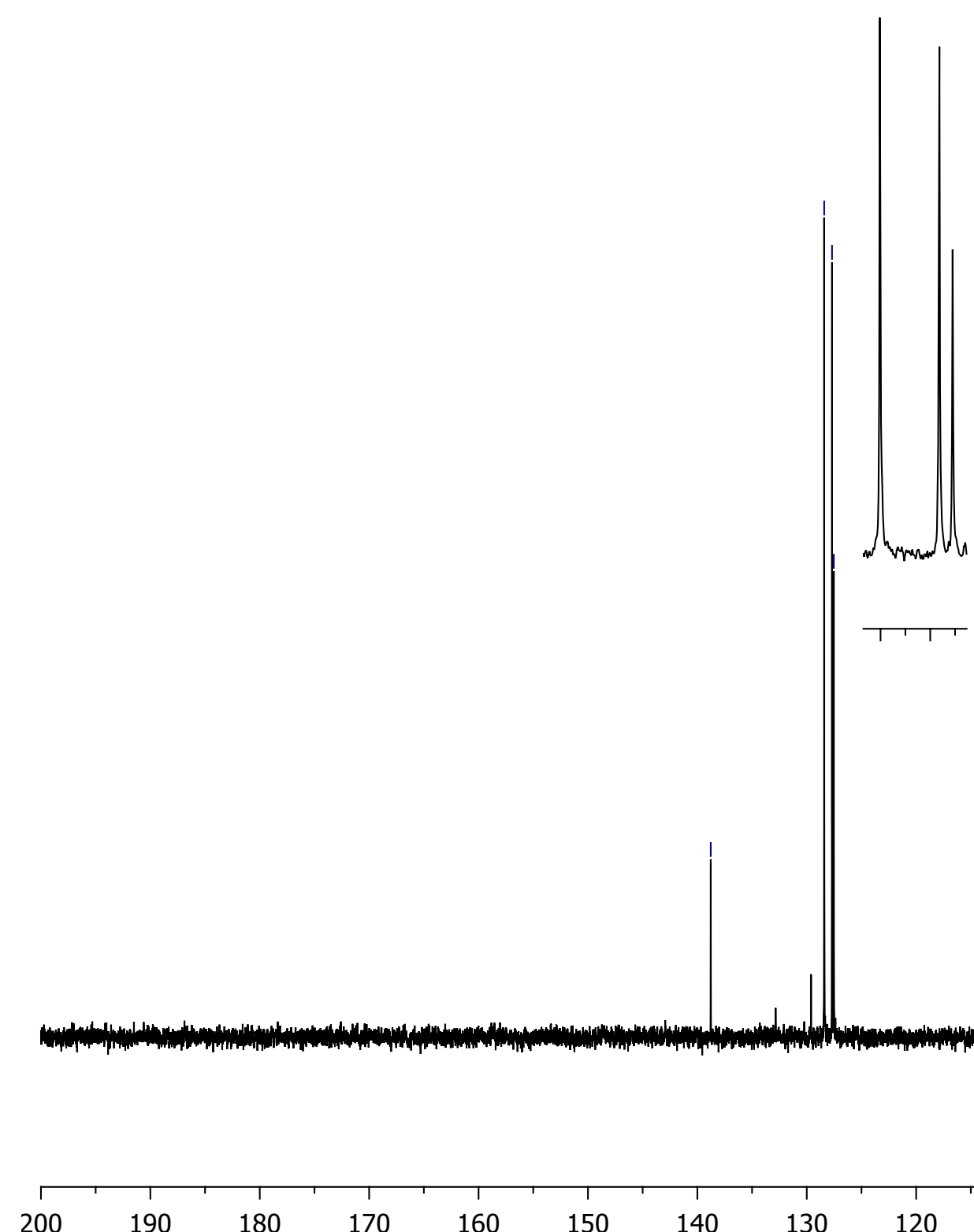


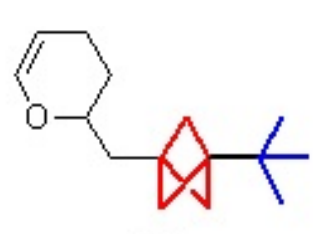

$6 f$

$\left({ }^{1} \mathrm{HNMR}, 400 \mathrm{MHz}, \mathrm{CDC}\right.$ )

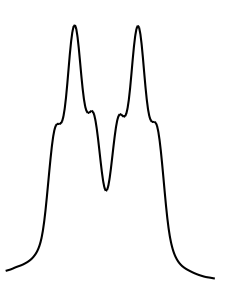

6.34

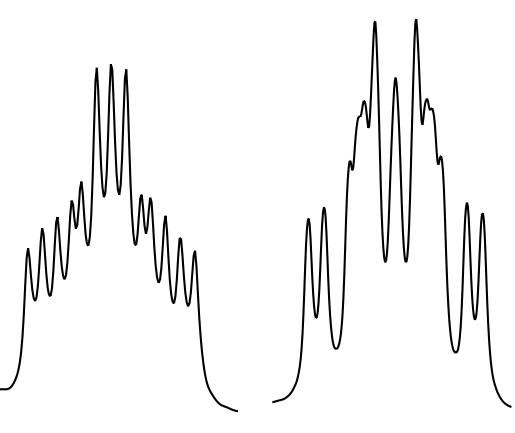

4.64
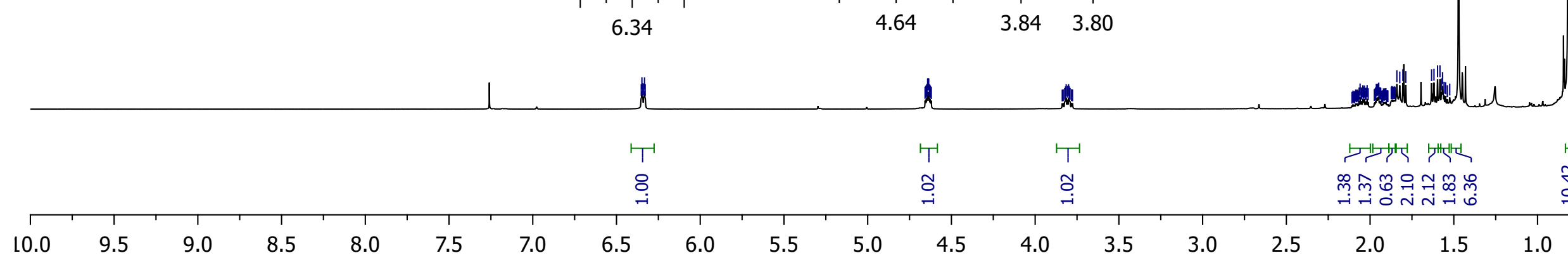

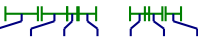

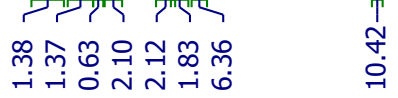




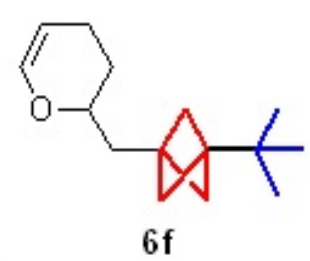

$\left({ }^{13} \mathrm{CNMR}, 100 \mathrm{MHz}, \mathrm{CDC}_{3}\right)$
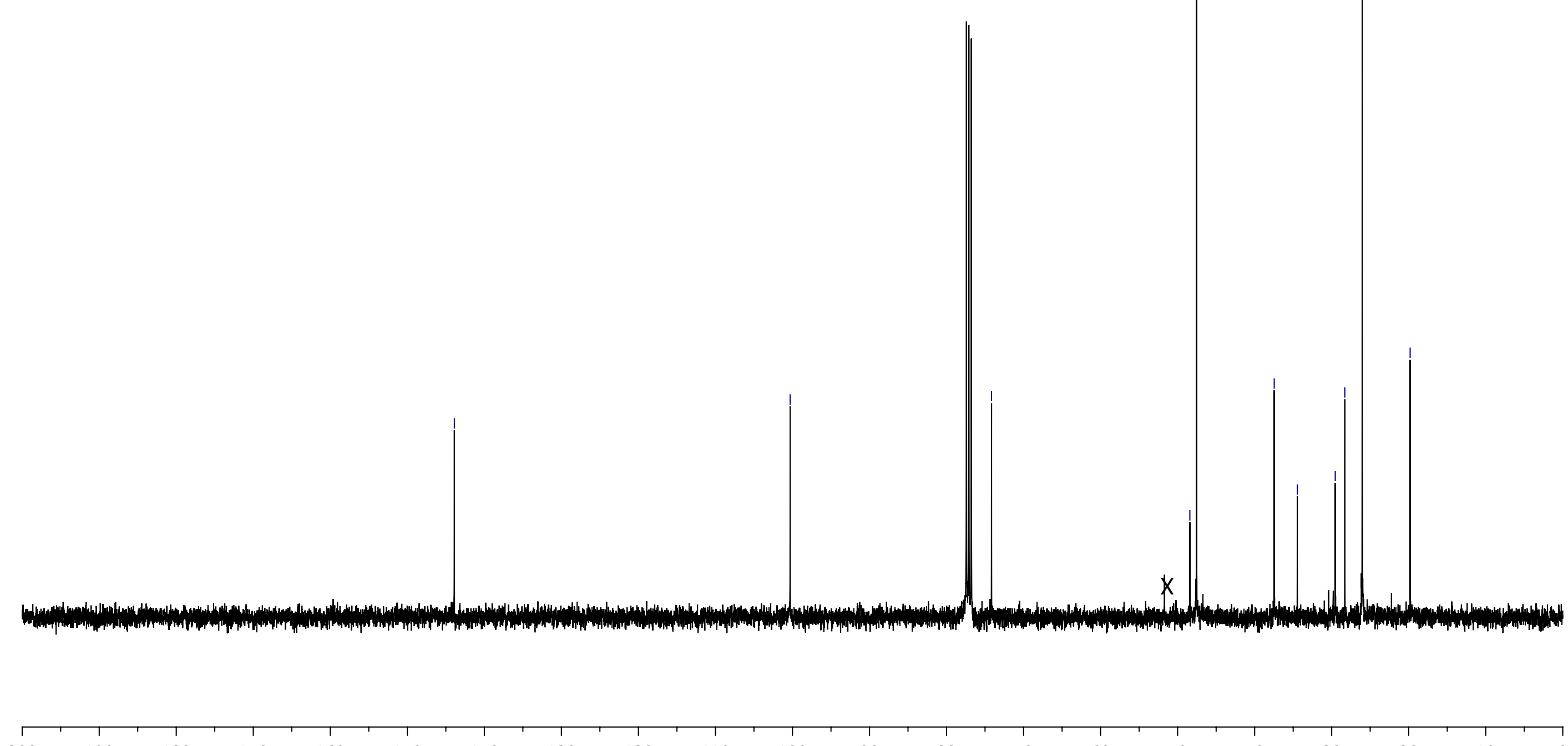

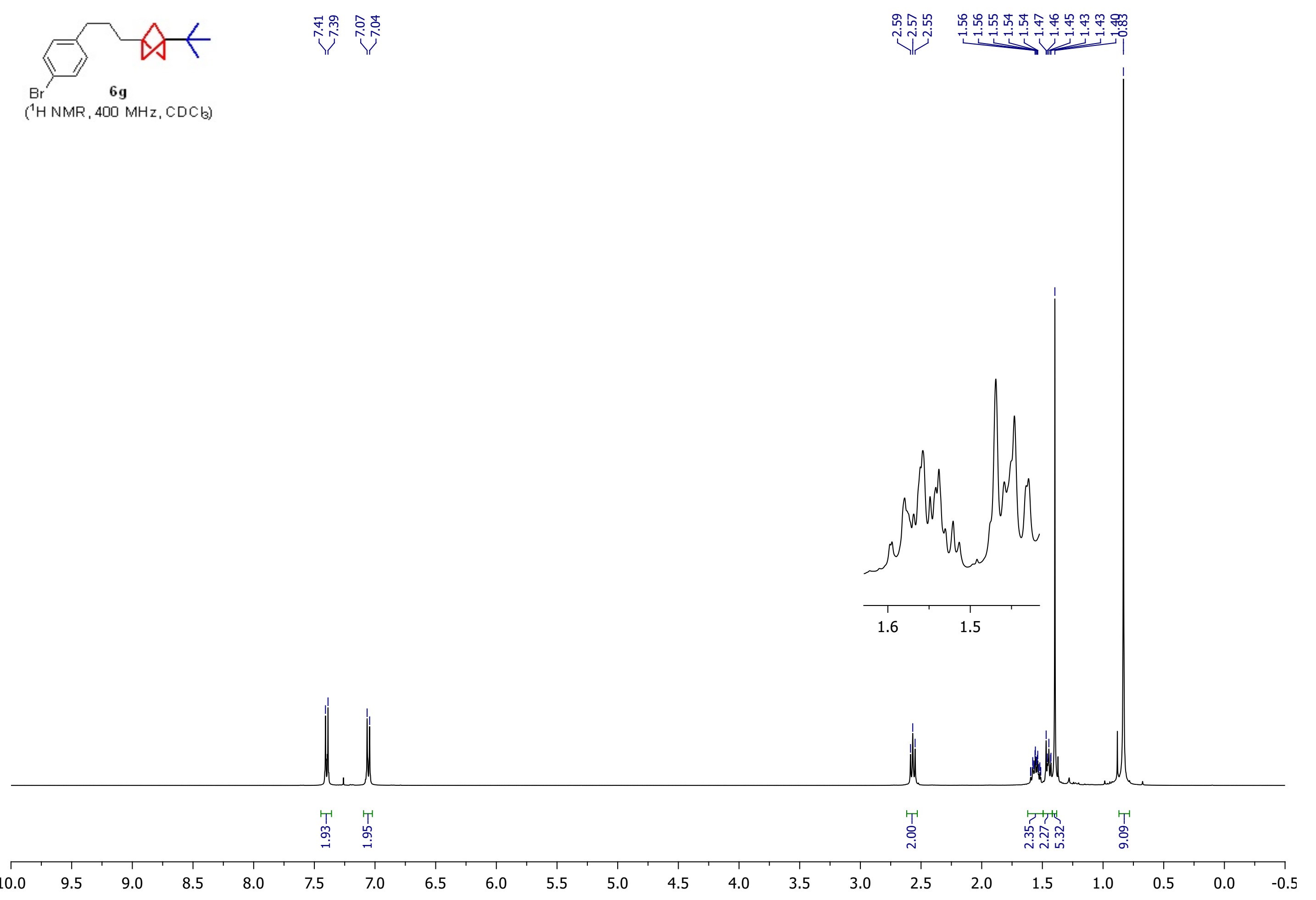


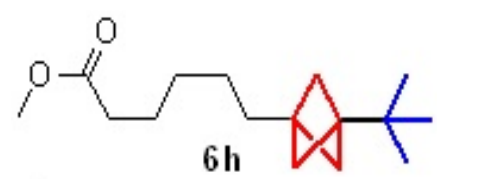

( ${ }^{1} \mathrm{H} N M R, 400 \mathrm{MHz}, \mathrm{CDC} B$ )

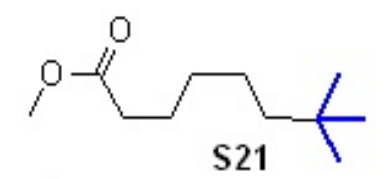

( ${ }^{1} \mathrm{HNMR}, 400 \mathrm{MHz}, \mathrm{CDC}$ )
고솟

II 


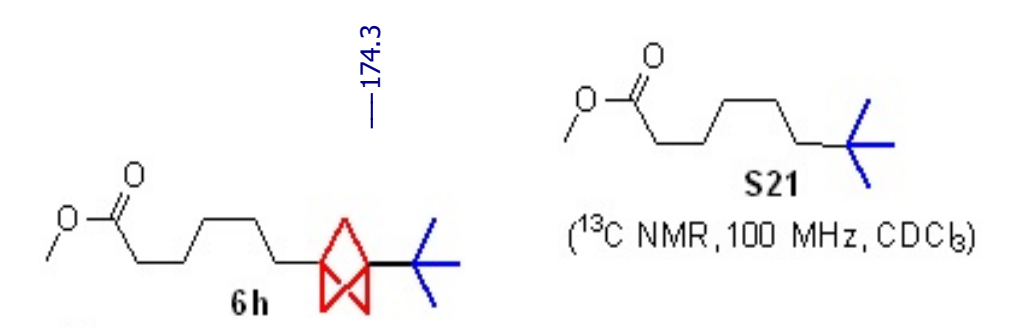

$\left({ }^{13} \mathrm{CNMR}, 100 \mathrm{MHz}, \mathrm{CDCl}\right)$

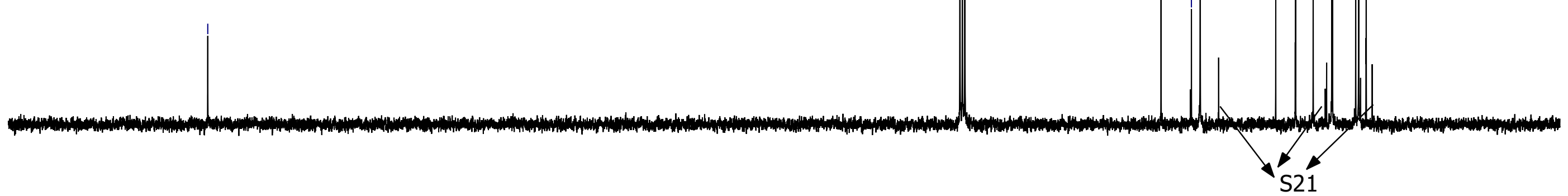




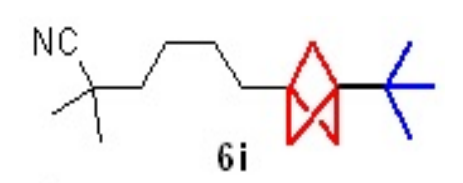

( ${ }^{1} \mathrm{HNMR}, 400 \mathrm{MHz}, \mathrm{CDCl}$ )

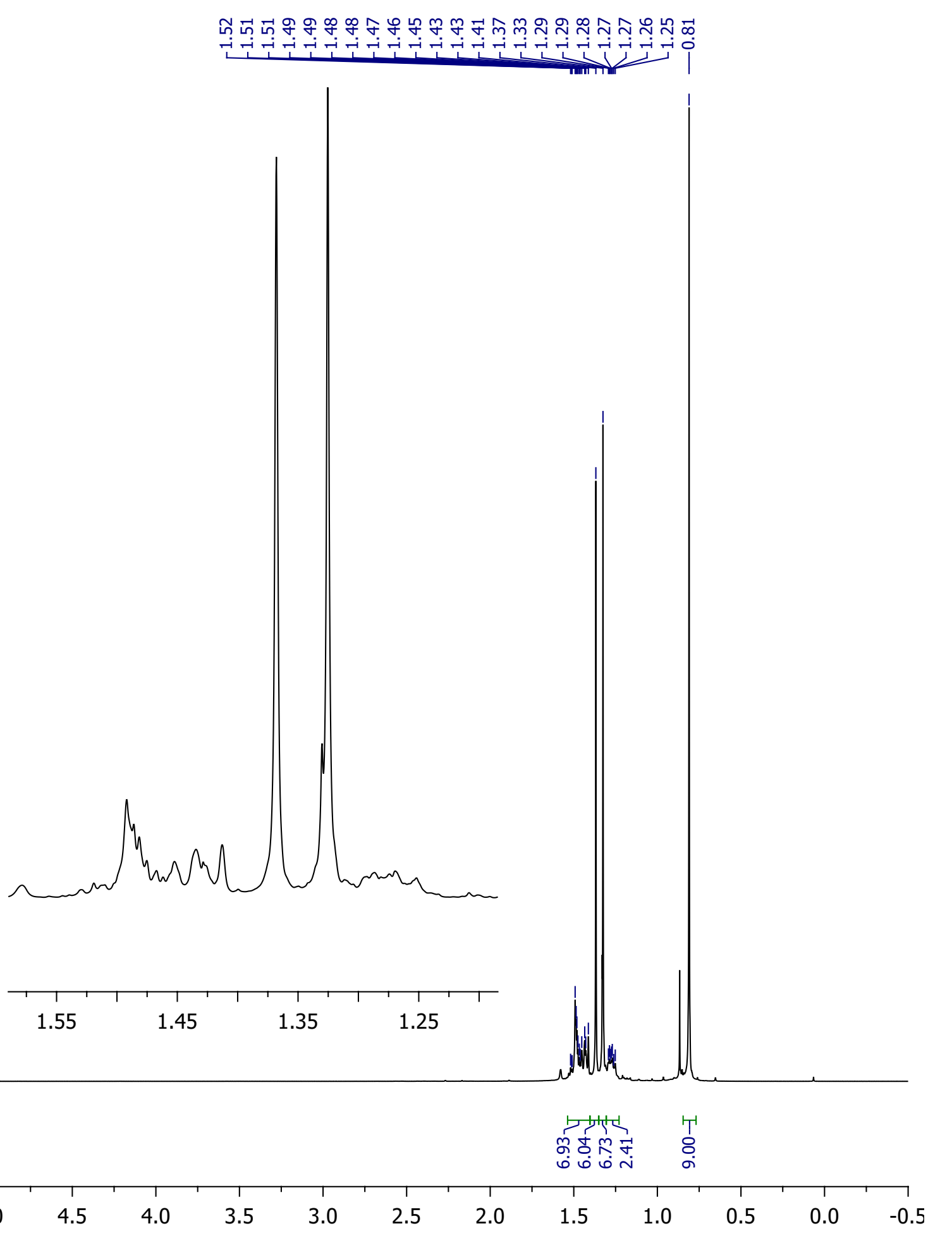




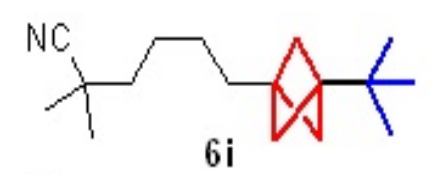

$\left({ }^{13} \mathrm{CNMR}, 100 \mathrm{MHz}, \mathrm{CDCl}\right)$

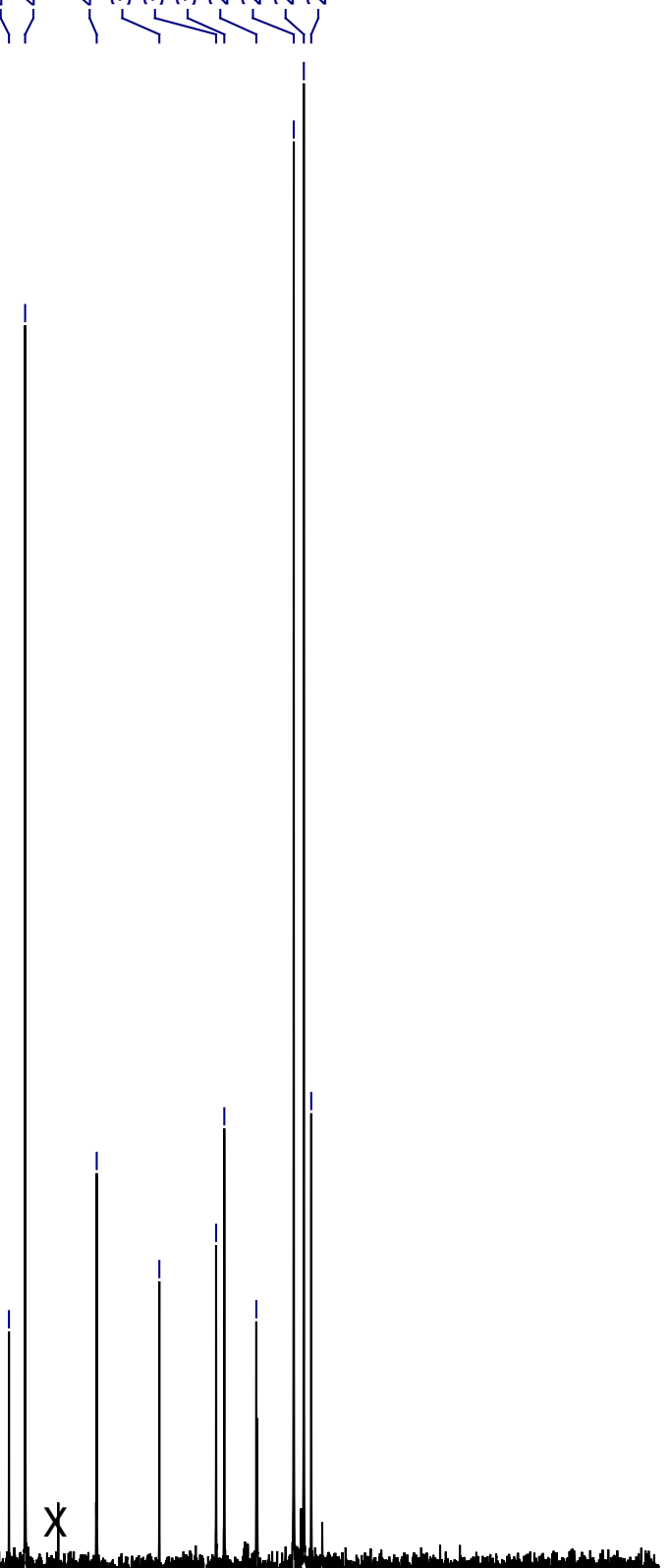




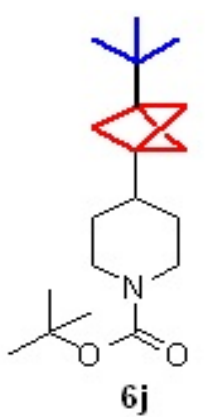

( $\left.{ }^{1} \mathrm{HNMR}, 400 \mathrm{MHz}, \mathrm{CDCl}_{3}\right)$
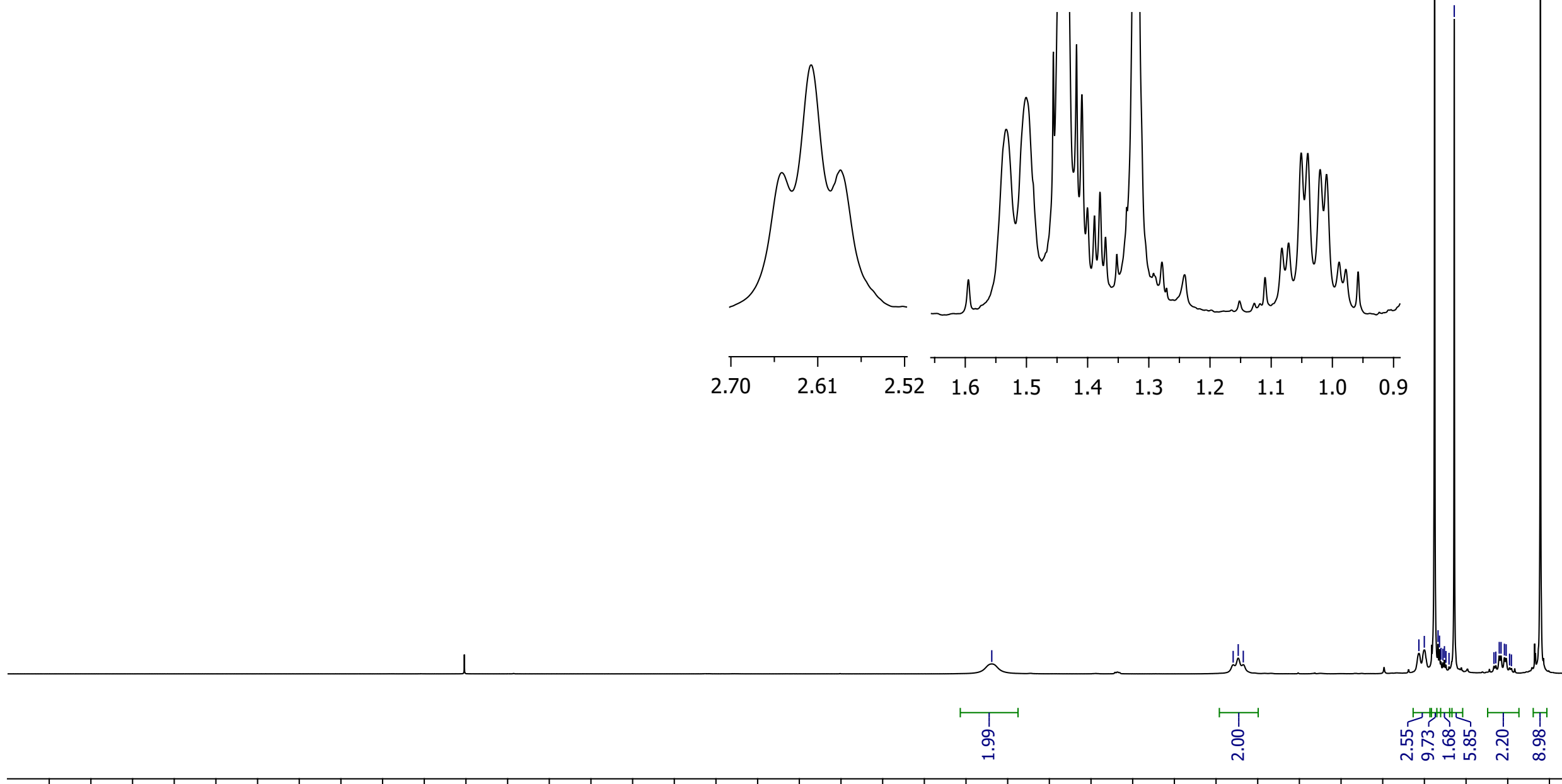


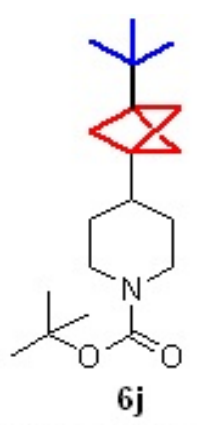

$\left({ }^{13} \mathrm{CNMR}, 100 \mathrm{MHz}, \mathrm{CDCl}\right)$

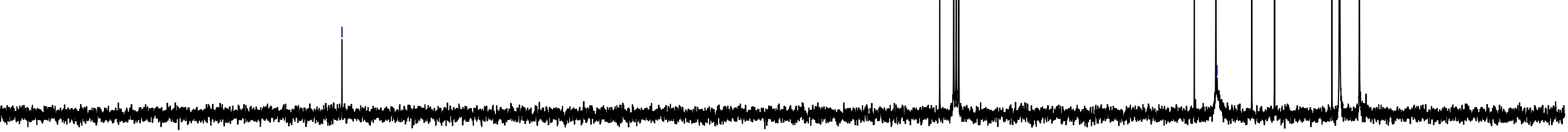




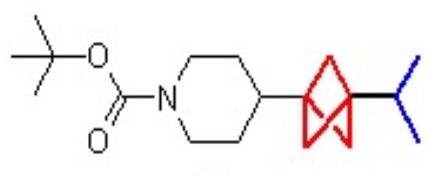

$6 k$

( ${ }^{\mathrm{HNMR}}, 400 \mathrm{MHz}, \mathrm{CDCl}$ )

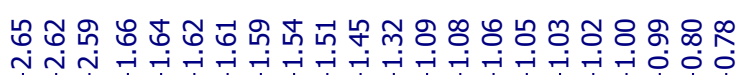

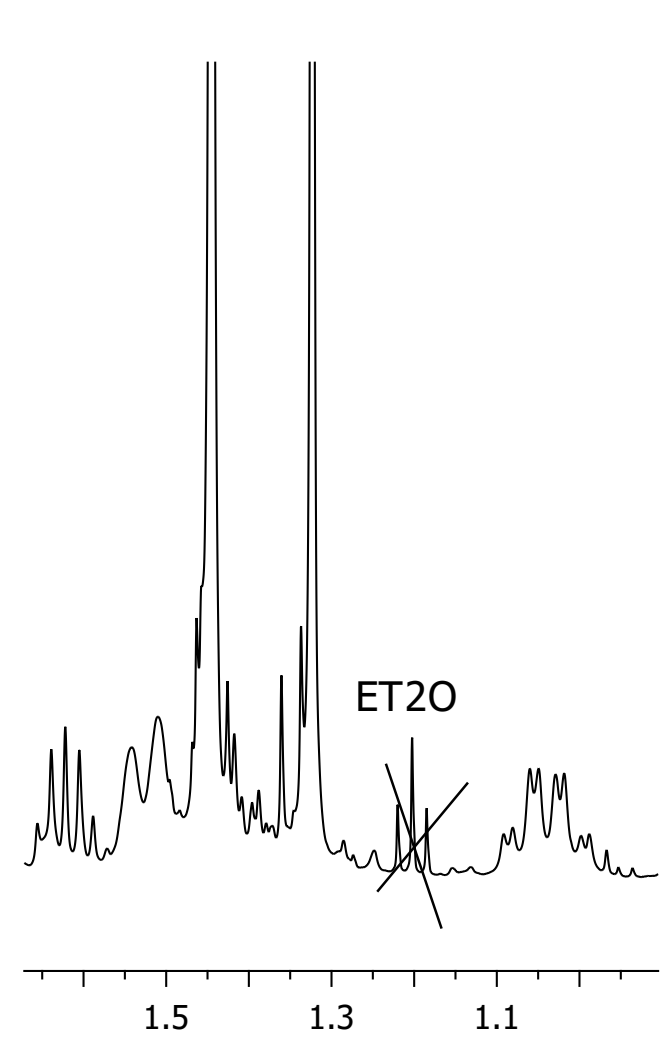

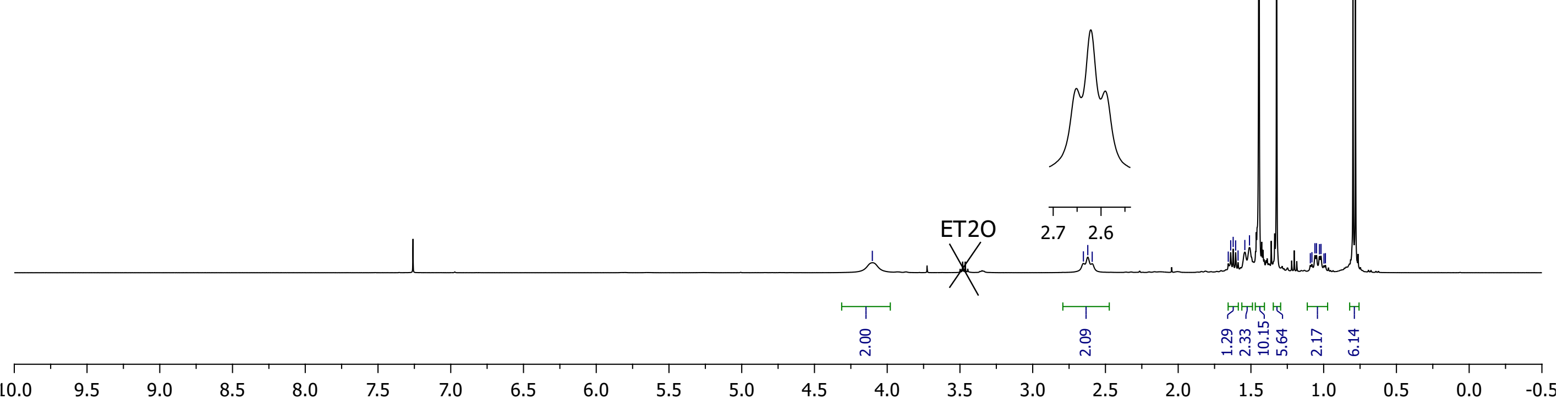




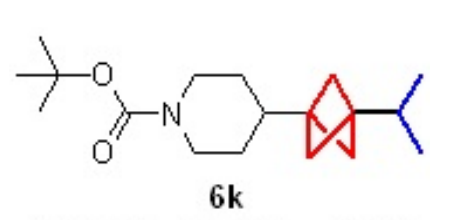

$\left({ }^{13} \mathrm{CNMR}, 100 \mathrm{MHz}, \mathrm{CDCl}\right)$

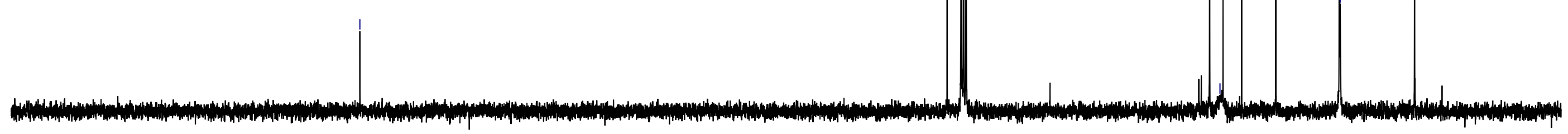




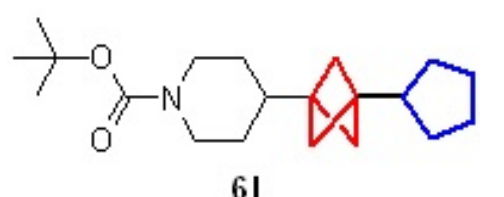

('H NMR, $400 \mathrm{MHz}, \mathrm{CDCl}$ )

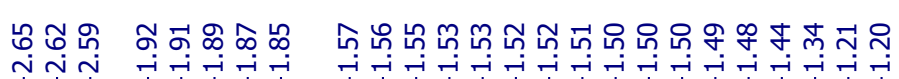

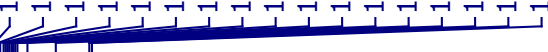

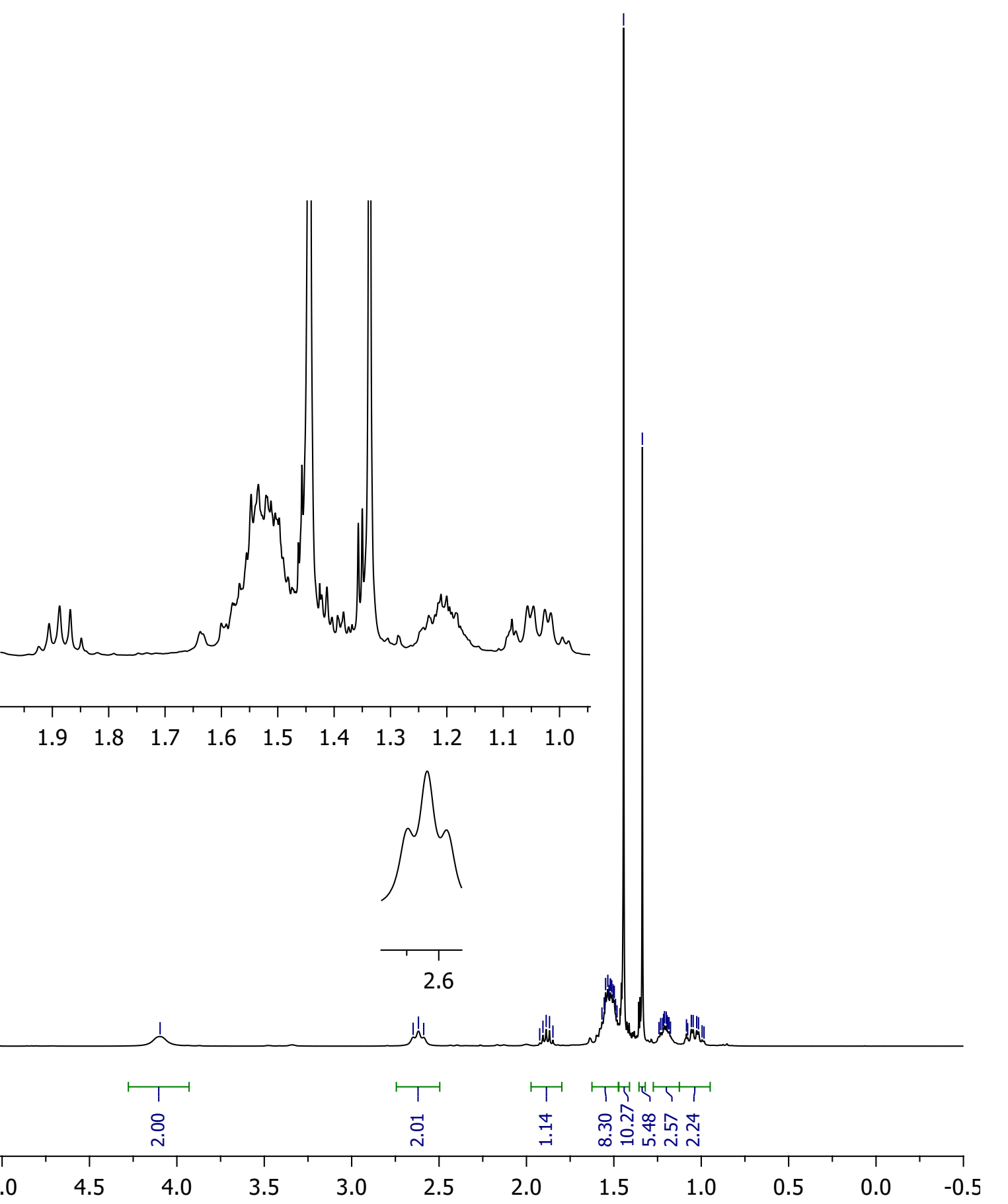




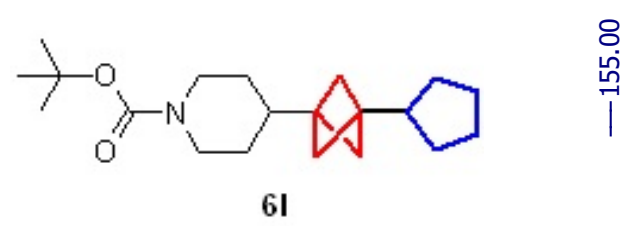

$\left({ }^{13} \mathrm{CNMR}, 100 \mathrm{MHz}, \mathrm{CDCb}\right)$ 


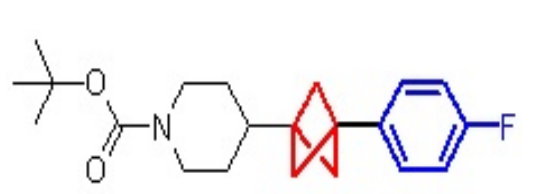

$6 \mathrm{~m}$

( ${ }^{H} \mathrm{NMR}, 400 \mathrm{MHz}, \mathrm{CDC} 6$ )

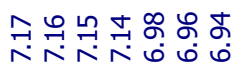

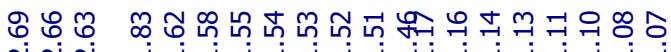
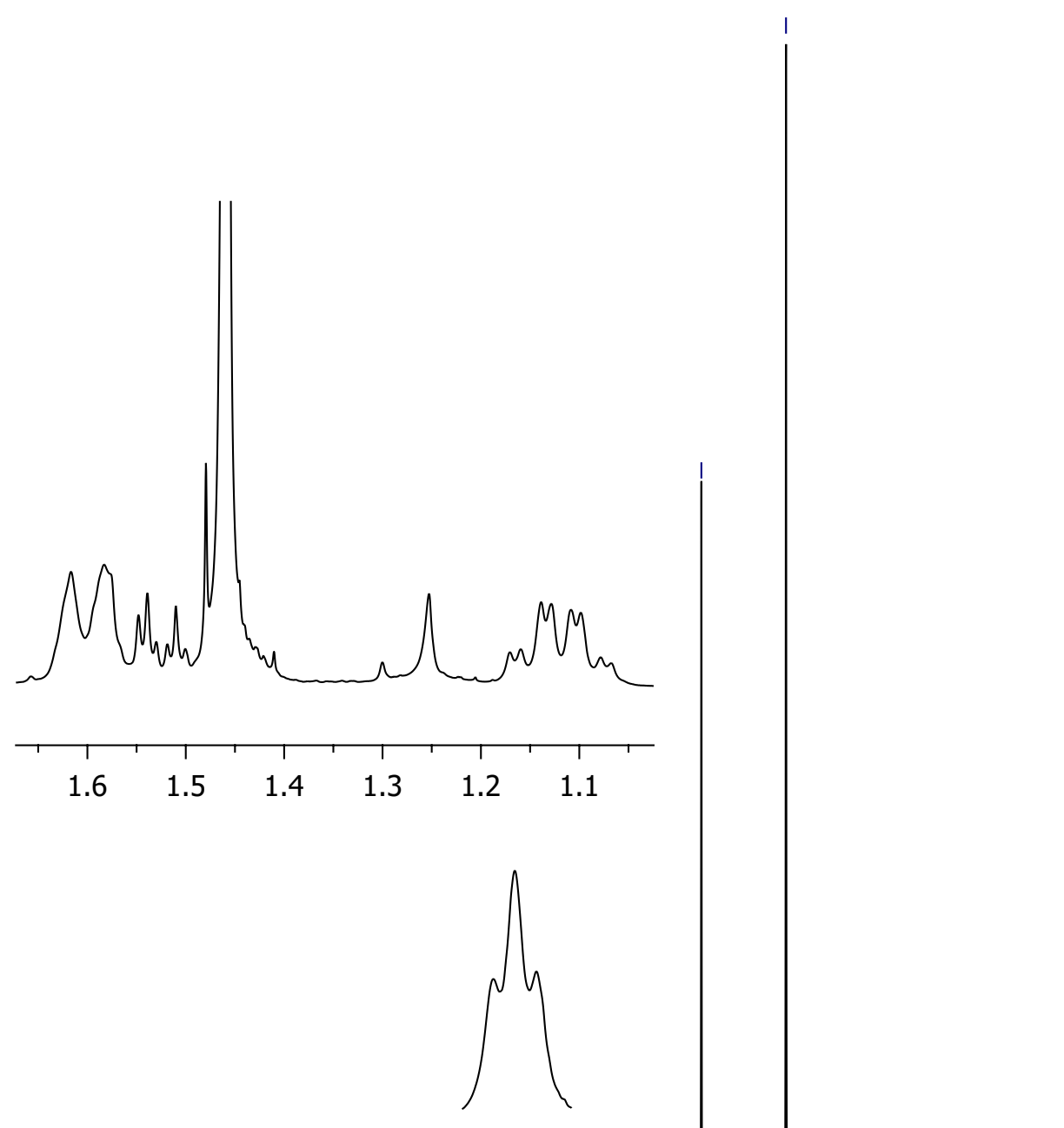

2.7

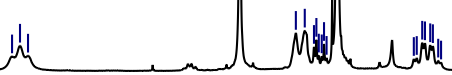

$\begin{array}{ll}\text { TT } & \text { T' } \\ 0 & 0 \\ \text { i } & \text { i }\end{array}$

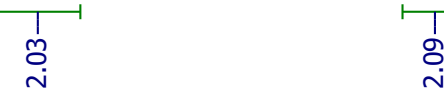




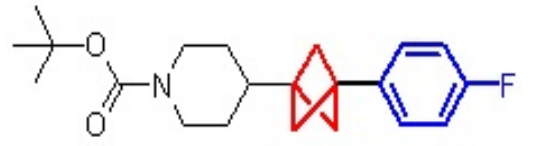

$6 \mathrm{~m}$

$\left({ }^{13} \mathrm{CNMR}, 100 \mathrm{MHz}, \mathrm{CDC} 3\right)$

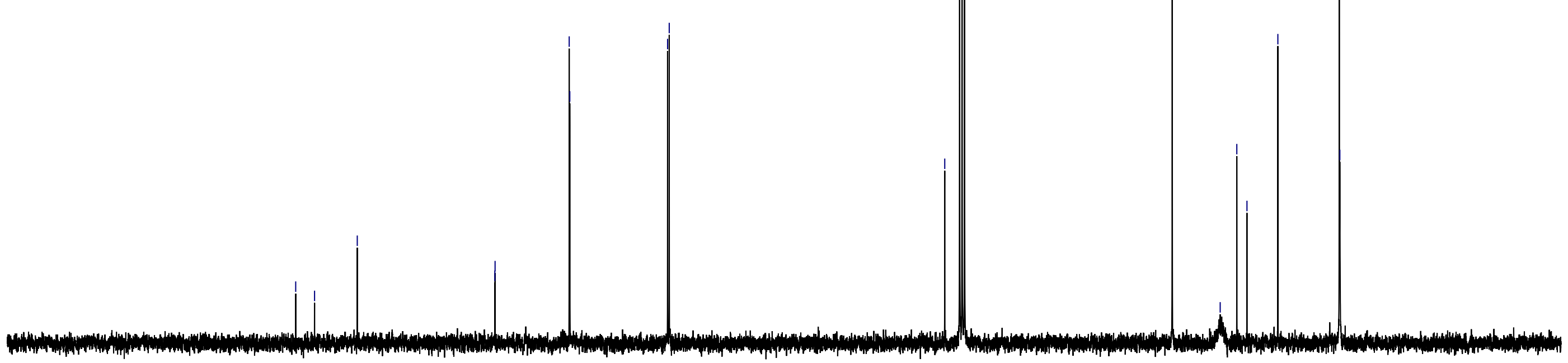




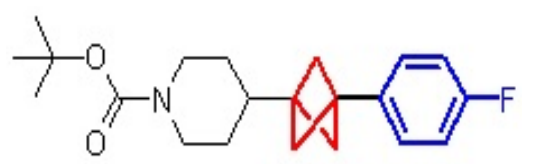

$\left({ }^{19} \mathrm{~F} \mathrm{NMR}, 376 \mathrm{MHz}, \mathrm{CDCl}\right)$ 


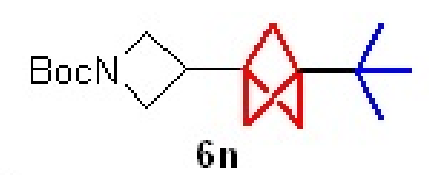

( ${ }^{1} \mathrm{HNMR}, 400 \mathrm{MHz}, \mathrm{CDC} b$ )
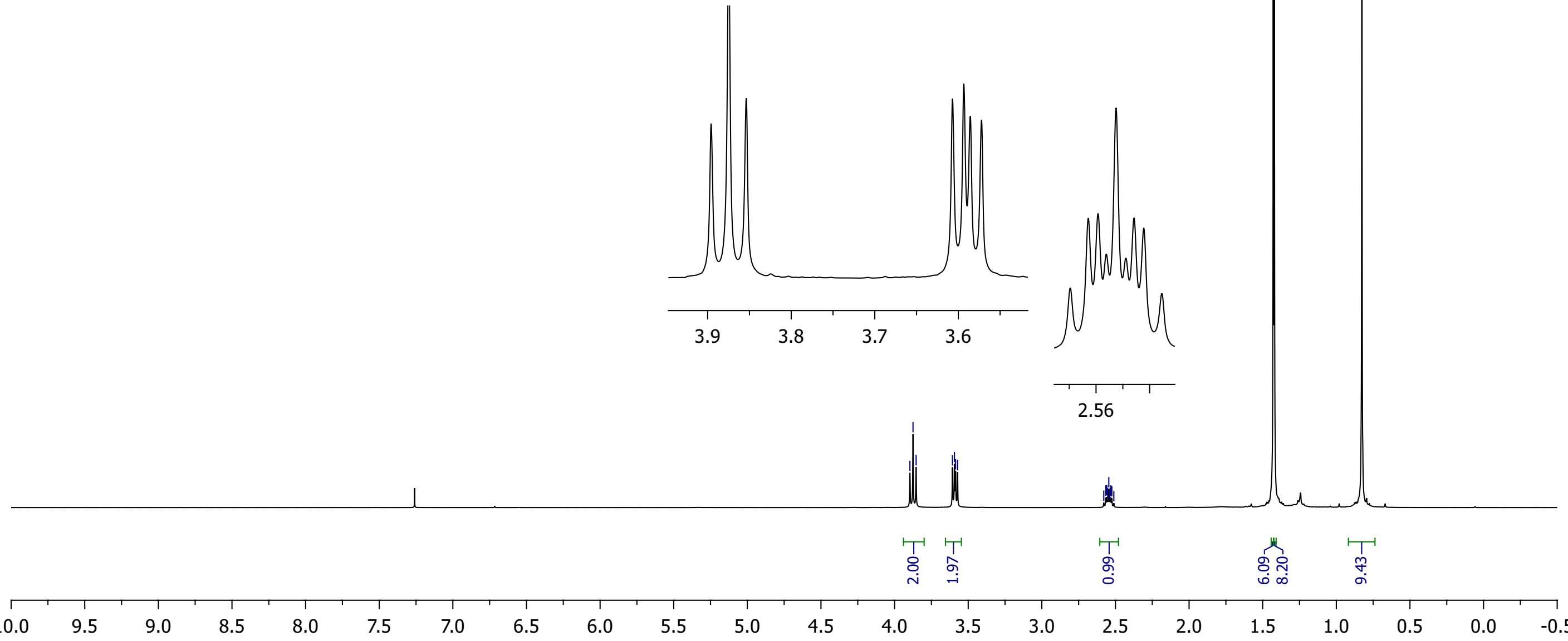


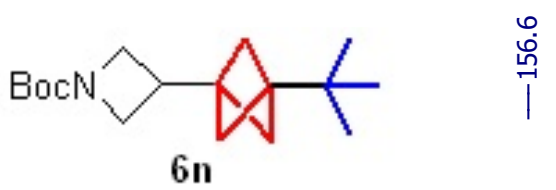

$\left({ }^{13} \mathrm{CNMR}, 100 \mathrm{MHz}, \mathrm{CDCl}\right)$

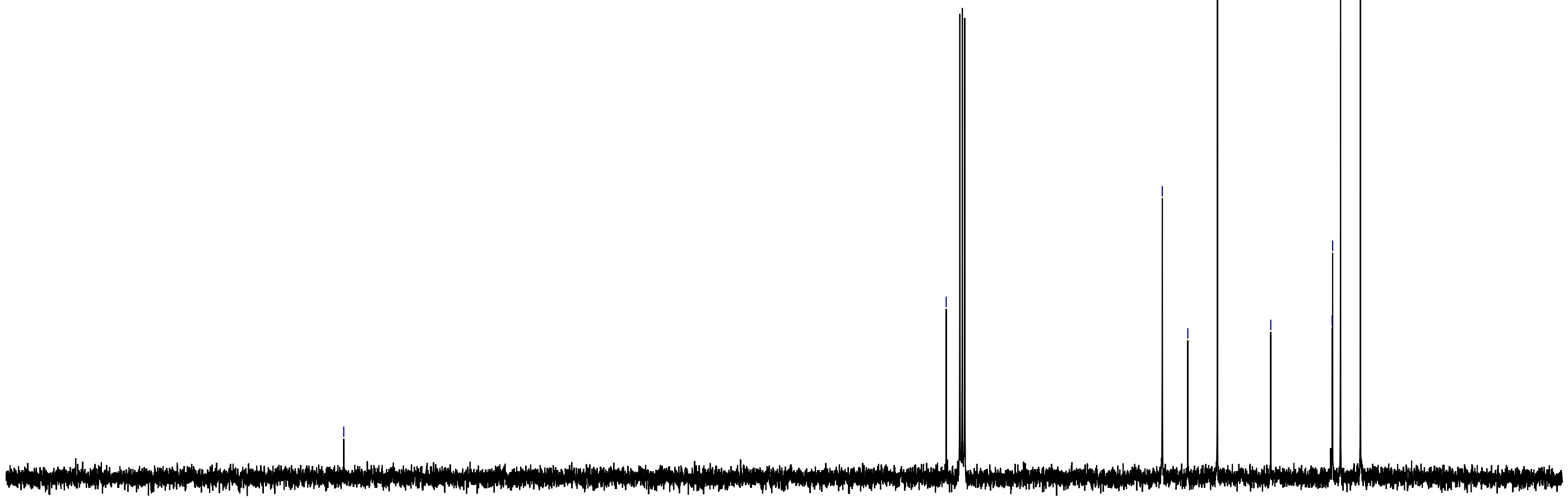




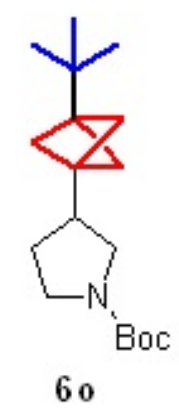

( ${ }^{H} \mathrm{NMMR}, 400 \mathrm{MHz}, \mathrm{CDCl}_{3}$ )

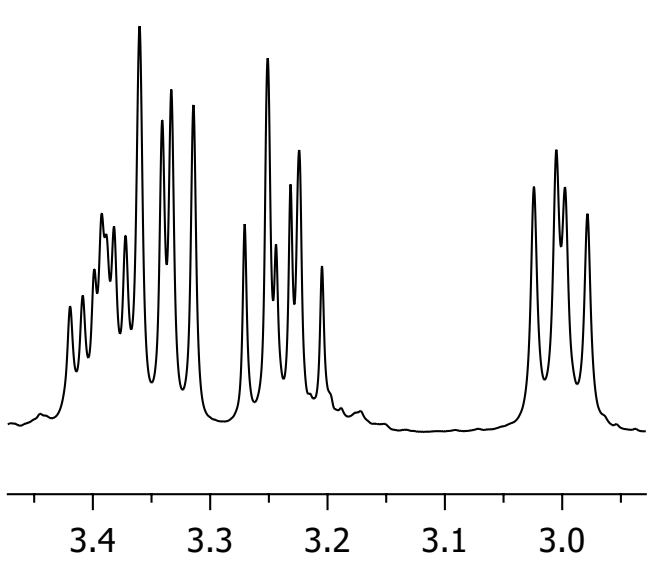

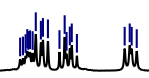

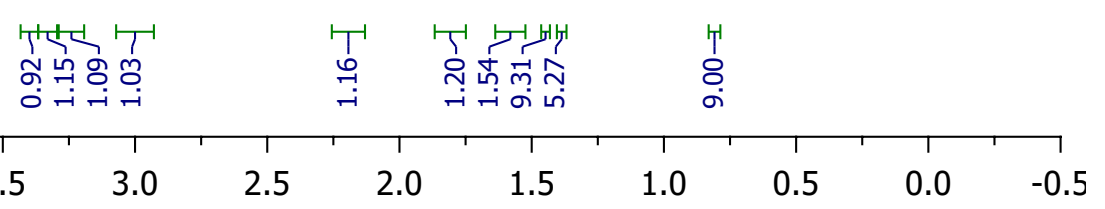




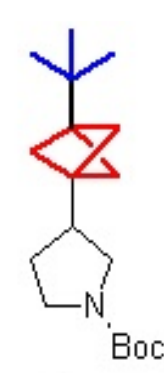

$\left({ }^{13} \mathrm{C} \mathrm{NMR}, 100 \mathrm{MHz}, \mathrm{CDCl} 3\right)$

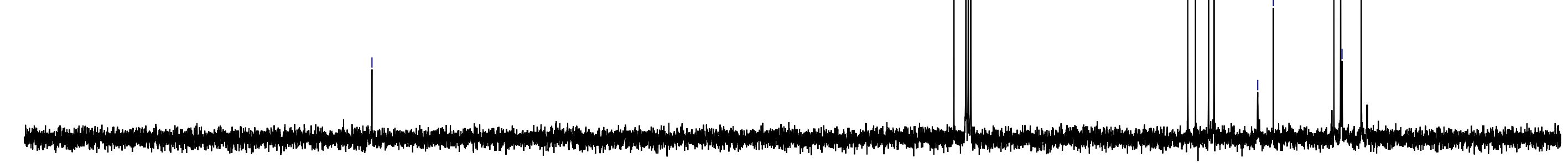




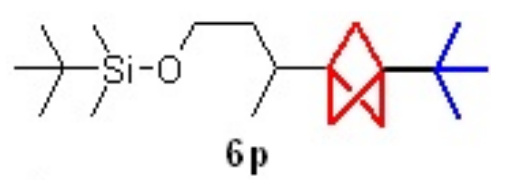

('HNMR, $400 \mathrm{MHz}, \mathrm{CDCl}$ )

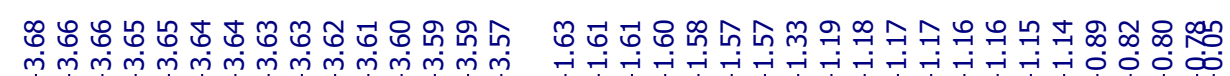

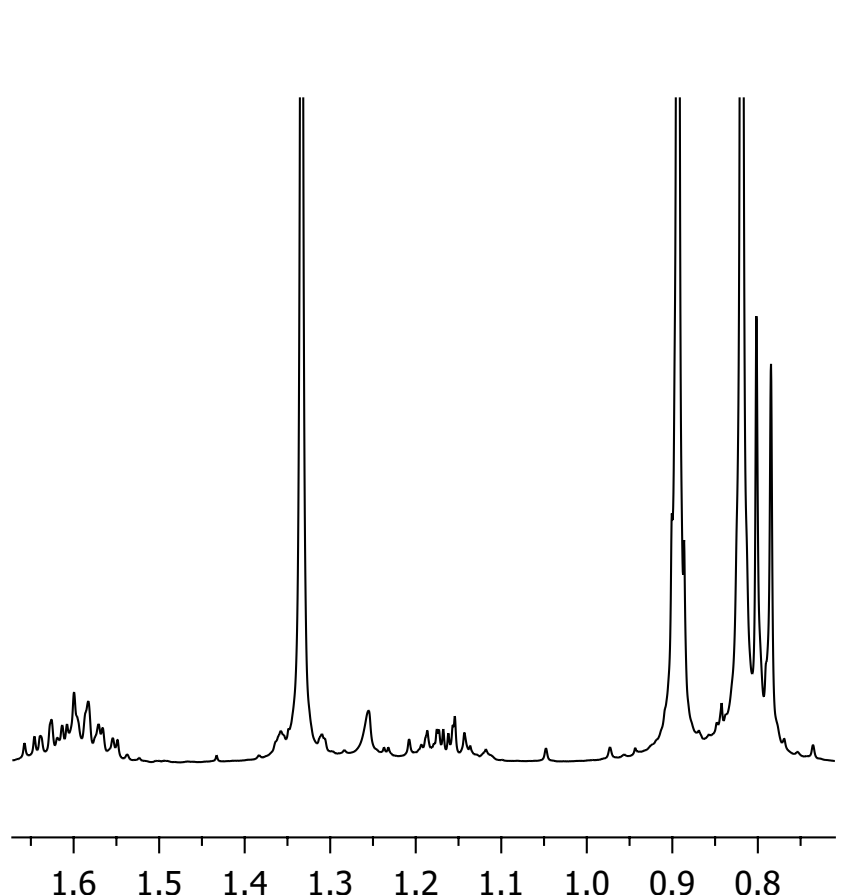

$\begin{array}{lllllllll}1.6 & 1.5 & 1.4 & 1.3 & 1.2 & 1.1 & 1.0 & 0.9 & 0.8\end{array}$

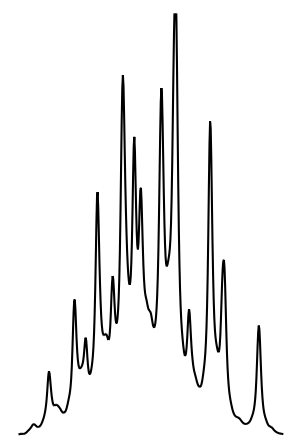

3.65

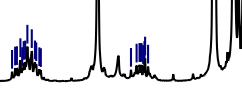

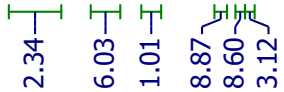




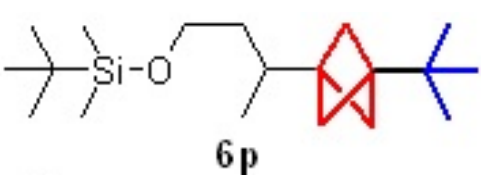

$\left({ }^{13} \mathrm{CNMR}, 100 \mathrm{MHz}, \mathrm{CDCl}\right)$ 


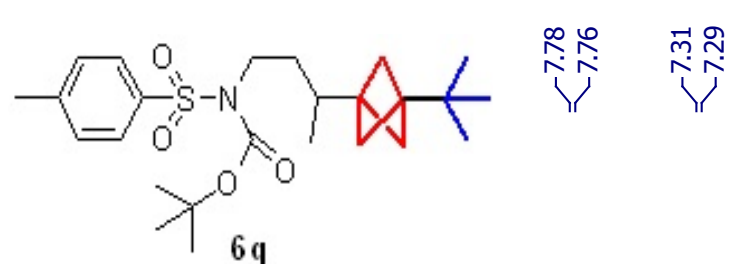

( ${ }^{\mathrm{HNMR}}, 400 \mathrm{MHz}, \mathrm{CDCl}$ )
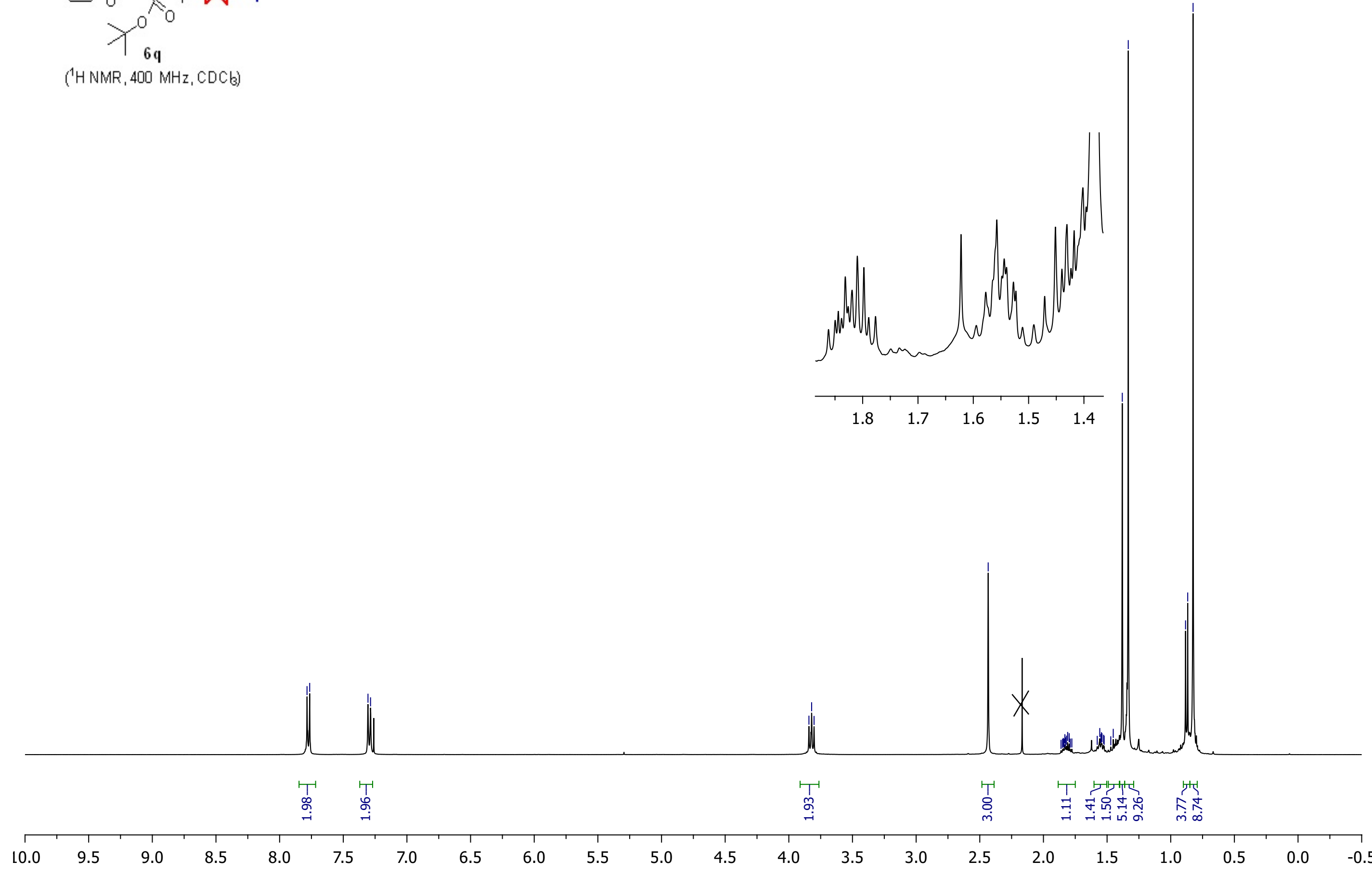


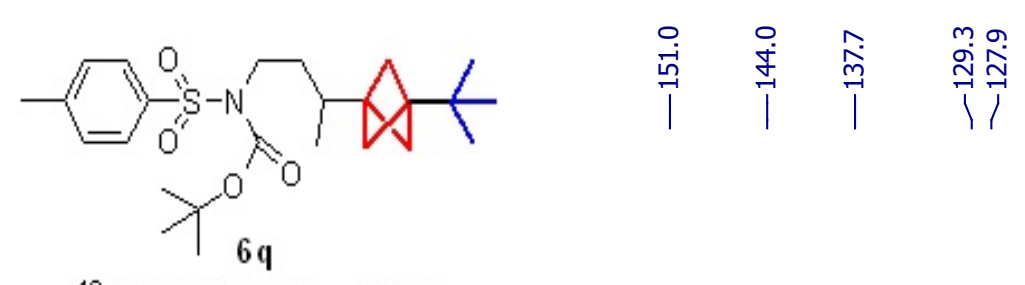

$\left({ }^{13} \mathrm{CNMR}, 100 \mathrm{MHz}, \mathrm{CDC} 3\right)$

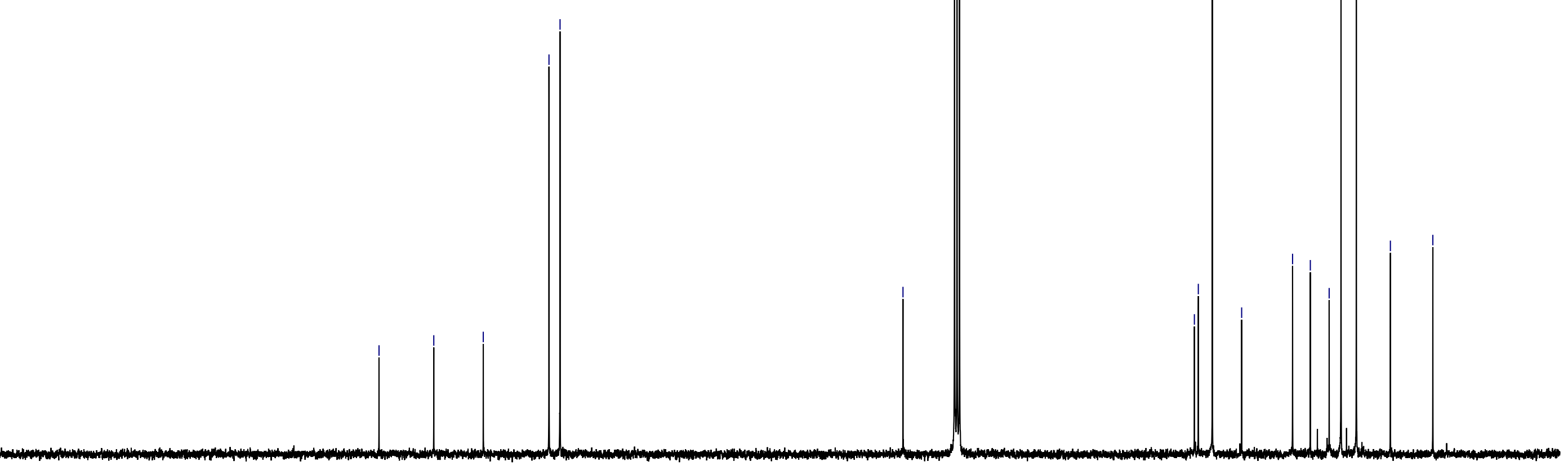

